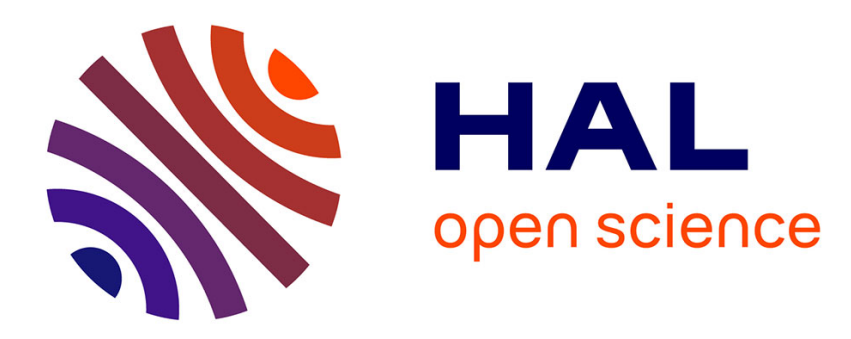

\title{
The chemistry influencing ODEs in the Polar Boundary Layer in spring: a model study
}

\author{
M. Piot, R. von Glasow
}

\section{To cite this version:}

M. Piot, R. von Glasow. The chemistry influencing ODEs in the Polar Boundary Layer in spring: a model study. Atmospheric Chemistry and Physics Discussions, 2008, 8 (2), pp.7391-7453. hal00304104

\section{HAL Id: hal-00304104 https://hal.science/hal-00304104}

Submitted on 16 Apr 2008

HAL is a multi-disciplinary open access archive for the deposit and dissemination of scientific research documents, whether they are published or not. The documents may come from teaching and research institutions in France or abroad, or from public or private research centers.
L'archive ouverte pluridisciplinaire HAL, est destinée au dépôt et à la diffusion de documents scientifiques de niveau recherche, publiés ou non, émanant des établissements d'enseignement et de recherche français ou étrangers, des laboratoires publics ou privés. 
Atmos. Chem. Phys. Discuss., 8, 7391-7453, 2008

www.atmos-chem-phys-discuss.net/8/7391/2008/

(c) Author(s) 2008. This work is distributed under

the Creative Commons Attribution 3.0 License.

\section{The chemistry influencing ODEs in the Polar Boundary Layer in spring: a model study}

M. Piot ${ }^{1}$ and R. von Glasow ${ }^{1,}$

${ }^{1}$ Institute of Environmental Physics, University of Heidelberg, Heidelberg, Germany *now at: School of Environmental Sciences, University of East Anglia, Norwich, UK

Received: 8 January 2008 - Accepted: 13 February 2008 - Published: 16 April 2008 Correspondence to: R. von Glasow (r.von-glasow@uea.ac.uk)

Published by Copernicus Publications on behalf of the European Geosciences Union.
The chemistry influencing ODEs

M. Piot and R. von

Glasow

ACPD

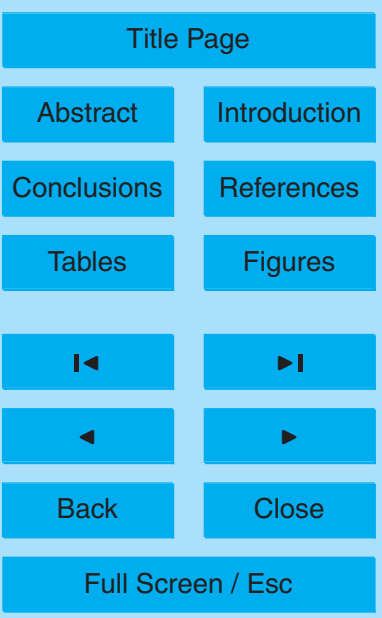

Printer-friendly Version

Interactive Discussion 


\section{Abstract}

Near-total depletions of ozone have been observed in the Arctic spring since the mid 1980s. The autocatalytic cycles involving reactive halogens are now recognized to be of main importance for Ozone Depletion Events (ODEs) in the Polar Boundary Layer 5 (PBL). We present sensitivity studies using the model MISTRA in the box-model mode on the influence of chemical species on these ozone depletion processes. In order to test the sensitivity of the chemistry under polar conditions, we compared base runs undergoing fluxes of either $\mathrm{Br}_{2}, \mathrm{BrCl}$, or $\mathrm{Cl}_{2}$ to induce ozone depletions, with similar runs including a modification of the chemical conditions. The role of $\mathrm{HCHO}, \mathrm{H}_{2} \mathrm{O}_{2}, \mathrm{DMS}$, $10 \mathrm{Cl}_{2}, \mathrm{C}_{2} \mathrm{H}_{4}, \mathrm{C}_{2} \mathrm{H}_{6}, \mathrm{HONO}, \mathrm{NO}_{2}$, and $\mathrm{RONO}_{2}$ was investigated. Cases with elevated mixing ratios of $\mathrm{HCHO}, \mathrm{H}_{2} \mathrm{O}_{2}$, DMS, $\mathrm{Cl}_{2}$, and $\mathrm{HONO}$ induced a shift in bromine speciation from $\mathrm{Br} / \mathrm{BrO}$ to $\mathrm{HOBr} / \mathrm{HBr}$, while high mixing ratios of $\mathrm{C}_{2} \mathrm{H}_{6}$ induced a shift from $\mathrm{HOBr} / \mathrm{HBr}$ to $\mathrm{Br} / \mathrm{BrO}$. Cases with elevated mixing ratios of $\mathrm{HONO}, \mathrm{NO}_{2}$, and $\mathrm{RONO}_{2}$ induced a shift to $\mathrm{BrNO}_{2} / \mathrm{BrONO}_{2}$. The shifts from $\mathrm{Br} / \mathrm{BrO}$ to $\mathrm{HOBr} / \mathrm{HBr}$ accelerated the

15 aerosol debromination, but also increased the total amount of deposited bromine at the surface (mainly via increased deposition of $\mathrm{HOBr}$ ). These shifts to $\mathrm{HOBr} / \mathrm{HBr}$ also hindered the $\mathrm{BrO}$ self-reaction. In these cases, the ozone depletion was slowed down, where increases in $\mathrm{H}_{2} \mathrm{O}_{2}$ and $\mathrm{HONO}$ had the greatest effect. The tests with increased mixing ratios of $\mathrm{C}_{2} \mathrm{H}_{4}$ highlighted the decrease in $\mathrm{HO}_{x}$ which reduced the production of $\mathrm{HOBr}$ from bromine radicals. In addition, the direct reaction of $\mathrm{C}_{2} \mathrm{H}_{4}$ with bromine atoms led to less available reactive bromine. The aerosol debromination was therefore strongly reduced. Ozone levels were highly affected by the chemistry of $\mathrm{C}_{2} \mathrm{H}_{4}$. $\mathrm{Cl}_{2}$-induced ozone depletions were found unrealistic compared to field measurements due to the rapid production of $\mathrm{CH}_{3} \mathrm{O}_{2}, \mathrm{HO}_{\mathrm{x}}$, and $\mathrm{ROOH}$ which rapidly convert reactive chlorine to $\mathrm{HCl}$ in a "chlorine counter-cycle". This counter-cycle efficiently reduces the concentration of reactive halogens in the boundary layer. Depending on the relative bromine and chlorine mixing ratios, the production of $\mathrm{CH}_{3} \mathrm{O}_{2}, \mathrm{HO}_{\mathrm{x}}$, and $\mathrm{ROOH}$ from the counter-cycle can significantly affect the bromine chemistry. Therefore, the pres-

The chemistry influencing ODEs

M. Piot and R. von

Glasow

Title Page

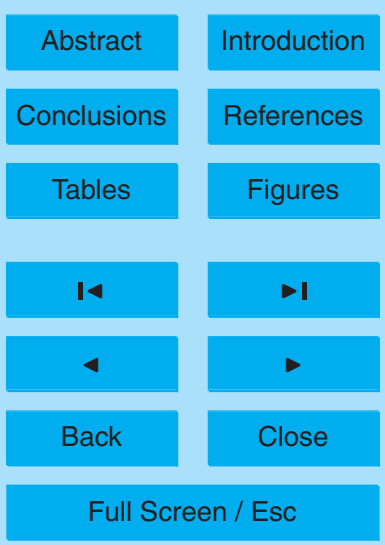

Printer-friendly Version

Interactive Discussion 
ence of both bromine and chlorine in the air may unexpectedly lead to a slow down in ozone destruction. For all $\mathrm{NO}_{\mathrm{y}}$ species studied $\left(\mathrm{HONO}, \mathrm{NO}_{2}, \mathrm{RONO}_{2}\right)$ the chemistry is characterized by an increased bromine deposition on snow reducing the amount of reactive bromine in the air. Ozone is less depleted under conditions of high mixing 5 ratios of $\mathrm{NO}_{\mathrm{x}}$. The production of $\mathrm{HNO}_{3}$ led to the acid displacement of $\mathrm{HCl}$, and the release of chlorine out of salt aerosols $\left(\mathrm{Cl}_{2}\right.$ or $\left.\mathrm{BrCl}\right)$ increased.

\section{Introduction}

Since the first reports of dramatic decreases of ozone (so-called ODEs) in the Arctic during spring (Bottenheim et al., 1986; Oltmans and Komhyr, 1986; Barrie et al., 10 1988), intensive efforts have been made to better understand the processes involved in the observed ozone loss. These events with low mixing ratios of ozone were correlated with high concentrations of filterable bromine (f-Br) (Barrie et al., 1988, 1989; Bottenheim et al., 1990). Later, BrO was observed with Long-Path DOAS (LP-DOAS, see Hausmann and Platt, 1994). Lehrer et al. (1997) showed a striking correlation be15 tween $\mathrm{f}-\mathrm{Br}$ and $\mathrm{BrO}$. During the ALERT2000 campaign, $\mathrm{Br}_{2}$ and $\mathrm{BrCl}$ were measured with mixing ratios as high as $30-35 \mathrm{pmol} \mathrm{mol}^{-1}$ in April, while $\mathrm{Cl}_{2}$ was not observed above its detection limit of about 2 pmol mol $^{-1}$ (Foster et al., 2001; Spicer et al., 2002). Similarly, results from the chemical amplification method used by Perner et al. (1999) showed mixing ratios of $\mathrm{ClO}_{\mathrm{x}}(\mathrm{Cl}+\mathrm{ClO})$ not exceeding $2 \mathrm{pmol} \mathrm{mol}^{-1}$ in spring. Only 20 the measurements by Tuckermann et al. (1997) in Spitzbergen in 1995 indicated ClO mixing ratios up to $21 \mathrm{pmol} \mathrm{mol}^{-1}$. These values were not observed, however, in the follow-up campaign in 1996. During the TOPSE aircraft program Ridley et al. (2003) showed that ozone depletions were actually widespread in the Arctic region. Indeed, Zeng et al. (2003) estimated that about $20 \%$ of the Arctic regions were influenced by 25 persistent near-surface ODEs in spring. This is in accordance with remote sensing data from satellites measuring column BrO (Richter et al., 1998; Wagner and Platt, 1998). For more details on polar ODEs, see Simpson et al. (2007b).

The chemistry influencing ODEs

M. Piot and R. von

Glasow

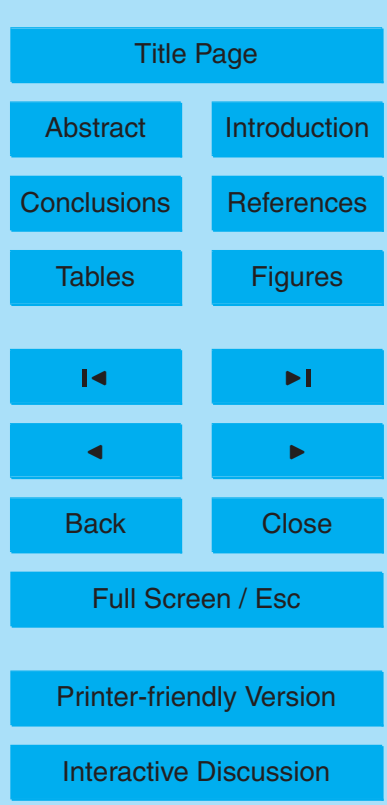


Under ODE conditions halogen catalytic reaction cycles are responsible for the depletion of $\mathrm{O}_{3}$. Halogens $(\mathrm{X}, \mathrm{Y}=\mathrm{Br}, \mathrm{Cl}, \mathrm{I})$ directly destroy ozone via three main cycles (see, e.g., von Glasow and Crutzen, 2007; Simpson et al., 2007b). Rate coefficients between iodine and ozone are highest, but we do not focus on iodine chemistry in this 5 paper. Bromine is the most abundant and therefore, the most efficient halogen species for the ozone destruction:

Cycle I:

$$
\begin{gathered}
2\left(\mathrm{O}_{3}+\mathrm{X} \longrightarrow \mathrm{XO}+\mathrm{O}_{2}\right) \\
\mathrm{XO}+\mathrm{XO} \longrightarrow 2 \mathrm{X}+\mathrm{O}_{2} \\
\longrightarrow \mathrm{X}_{2}+\mathrm{O}_{2} \\
\mathrm{X}_{2} \stackrel{h v}{\longrightarrow} 2 \mathrm{X}
\end{gathered}
$$

Net: $2 \mathrm{O}_{3} \longrightarrow 3 \mathrm{O}_{2}$

This cycle I is the fastest ozone-depleting reaction cycle for $\mathrm{X}=\mathrm{Br}$.

Cycle II:

$$
\begin{aligned}
& \mathrm{XO}+\mathrm{HO}_{2} \longrightarrow \mathrm{HOX}+\mathrm{O}_{2} \\
& \mathrm{HOX} \stackrel{h v}{\longrightarrow} \mathrm{OH}+\mathrm{X} \\
& \mathrm{CO}+\mathrm{OH} \stackrel{\mathrm{O}_{2}}{\longrightarrow} \mathrm{HO}_{2}+\mathrm{CO}_{2}
\end{aligned}
$$

Net: $\mathrm{O}_{3}+\mathrm{CO} \longrightarrow \mathrm{O}_{2}+\mathrm{CO}_{2}$

Reaction (5) is very fast and represents a main pathway for the production of HOX.

Cycle III:

$$
\begin{aligned}
\mathrm{XO}+\mathrm{YO} & \longrightarrow \mathrm{X}+\mathrm{Y}+\mathrm{O}_{2} \\
& \longrightarrow \mathrm{XY}+\mathrm{O}_{2} \\
& \longrightarrow \mathrm{X}+\mathrm{OYO}
\end{aligned}
$$

Net: $2 \mathrm{O}_{3} \longrightarrow 3 \mathrm{O}_{2}$

The chemistry influencing ODEs

M. Piot and R. von

Glasow

Title Page

Abstract

Introduction

Conclusions

References

Tables

Figures

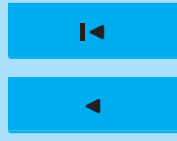

$\rightarrow$

Back

Close

Full Screen / Esc

Printer-friendly Version

Interactive Discussion 
The interhalogen Reactions (8) to (10) have similar effects on ozone to those of bromine itself.

If enough $\mathrm{CH}_{3} \mathrm{O}_{2}$ is present in the airmass, the following reaction might become a substantial pathway to convert $\mathrm{BrO}$ into other reactive halogen species (Aranda et al., 5 1997):

$$
\begin{aligned}
\mathrm{BrO}+\mathrm{CH}_{3} \mathrm{O}_{2} & \longrightarrow \mathrm{HOBr}+\mathrm{O}_{2} \\
& \longrightarrow \mathrm{Br}+\mathrm{HCHO}+\mathrm{HO}_{2}
\end{aligned}
$$

$\mathrm{HO}_{2}$ impacts the speciation of bromine species via reaction with $\mathrm{BrO}$ (see Reaction 5). In addition, it directly reacts with $\mathrm{Br}$ atoms to form $\mathrm{HBr}$ :

$10 \mathrm{Br}+\mathrm{HO}_{2} \longrightarrow \mathrm{HBr}+\mathrm{O}_{2}$

Reaction (5) is the most efficient one for the modification of the bromine speciation, followed by Reactions (11-12) (with an order of magnitude less efficient). The reaction rates of Reaction (13) remain usually small. However, it may become important when the ratio $[\mathrm{Br}]:[\mathrm{BrO}]$ increases (e.g., when ozone depletion is nearly complete).

15 In order to sustain a significant amount of reactive halogens in the gas phase, additional mechanisms involving the liquid and solid phases (aerosols, ice crystals/snow) are necessary to activate halides and recycle less-reactive gas phase halogens. In the early 1990s Fan and Jacob (1992) and McConnell et al. (1992) suggested the following important heterogeneous reaction path for the liberation of $\mathrm{Br}_{2}$ and $\mathrm{BrCl}$ from sea salt 20 (based on data from Eigen and Kustin, 1962), involving $\mathrm{HOBr}$ :

$\mathrm{HOX}_{\mathrm{aq}}+\mathrm{Y}^{-}+\mathrm{H}^{+} \longrightarrow \mathrm{XY}_{\mathrm{aq}}+\mathrm{H}_{2} \mathrm{O}$

The proportional release of $\mathrm{Br}_{2} / \mathrm{BrCl}$ from Reaction (14) was experimentally studied by Fickert et al. (1999). The required acidity may be supplied by strong acids, such as man-made $\mathrm{HNO}_{3}$ and $\mathrm{H}_{2} \mathrm{SO}_{4}$ (see also Mozurkewich, 1995; Tang and McConnell, 1996; Vogt et al., 1996). Reaction (14), releasing two bromine atoms in the gas phase from the uptake of $\mathrm{HOBr}$ is called the "bromine explosion" (Platt and Lehrer, 1996). The

8, 7391-7453, 2008

\section{The chemistry} influencing ODEs

M. Piot and R. von

Glasow

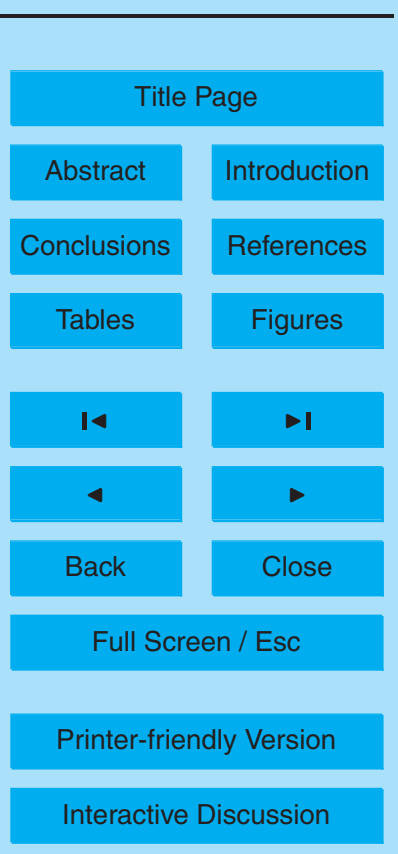


source of halogens in the PBL remains unclear. Recently, efforts to locate the source focused on freshly-new sea ice and frost flowers (Martin et al., 1995; Rankin et al., 2000; Kaleschke et al., 2004; Dominé et al., 2005), as they provide adequate surfaces, called "brine" (Richardson and Keller, 1966), containing highly concentrated halides.

5 Simpson et al. (2007a) found a high correlation between fresh sea ice and high levels of $\mathrm{BrO}$.

Box models (Fan and Jacob, 1992; McConnell et al., 1992; Tang and McConnell, 1996; Sander et al., 1997; Michalowski et al., 2000; Evans et al., 2003) and onedimensional models (Lehrer et al., 2004; Piot and von Glasow, 2007) have investigated 10 the reaction cycles and have increased our understanding of the halogen/ozone chemical processes. Piot and von Glasow (2007) modeled meteorological and chemical processes that may influence the occurrence of an ODE with the snow surface acting as an efficient recycling surface. They also investigated the relevance of observed levels of non-halogen species on the halogen/ozone chemistry. However, the relative importance of these relevant species in the Arctic on the ozone chemistry has to be better understood.

Numerous concentration and flux measurements of compounds in the Arctic have been reported in the literature, but the variability of these compounds in relation to the ozone/halogen chemistry needs a clearer investigation to better understand the occurrence of an ODE. In this paper, we examined the potential effects of the presence of several chemical species in the PBL on the ozone level. Several modifications (in mixing ratios or fluxes) compared to conditions in base runs are investigated for $\mathrm{HCHO}$, $\mathrm{H}_{2} \mathrm{O}_{2}$, DMS, $\mathrm{Cl}_{2}, \mathrm{C}_{2} \mathrm{H}_{4}, \mathrm{C}_{2} \mathrm{H}_{6}, \mathrm{HONO}, \mathrm{NO}_{2}$, and $\mathrm{RONO}_{2}$. Implications for the chemistry in the PBL are discussed in Sects. 4.3 to 4.9.

\section{Model description and setup}

We used the model MISTRA which was initially designed to study the physics and chemistry of the marine boundary layer (von Glasow et al., 2002a,b; von Glasow and

The chemistry influencing ODEs

M. Piot and R. von

Glasow

Title Page

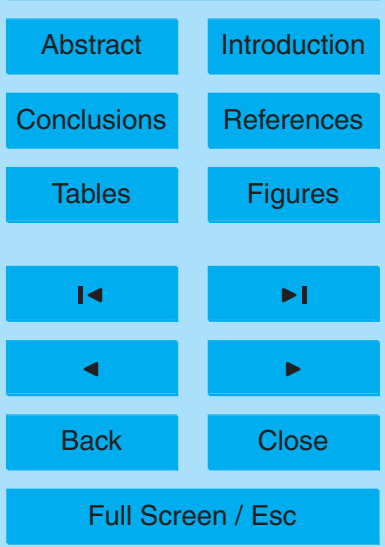

Printer-friendly Version

Interactive Discussion 
Crutzen, 2004) but was recently extended and applied also to Arctic conditions (Piot and von Glasow, 2007). MISTRA is a one-dimensional model which can also be used as a box model which is what we did for this study. In this study, we used the box model in the Lagrangian mode.

$5 \quad$ We chose the solar conditions (relevant for the calculation of photolysis frequencies) for Alert, Canada $\left(82.5^{\circ} \mathrm{N}, 62.3^{\circ} \mathrm{W}\right)$ as in early spring (solar declination of $+7^{\circ}$ ). We chose a boundary layer height of $300 \mathrm{~m}$, as often observed during spring in the high Arctic (Hopper and Hart, 1994; Hopper et al., 1998; Ridley et al., 2003). The relevant meteorological parameters in the box-model mode are the temperature, relative humid-

10 ity, and the particle size distribution. The uptake of gases by aerosols is temperature dependent (Schwartz, 1986) because the molecular speed, the gas phase diffusivity, and the reactive uptake depend on the temperature. We want to stress, however, that the temperature dependencies of the uptake parameters are based on estimates as found in the literature.

15 In the sensitivity studies we present in this paper we distinguish an airmass influenced by the presence of sea water (coastal conditions) from an aged airmass over snow-covered areas (background conditions). The airmass composition is modified by the presence of sea water (see Table 1). Sea salt aerosols (SSA) are only produced in runs under coastal conditions. They provide an additional source of potentially releasable bromine (Reaction 14) and represent an important medium for recycling less reactive bromine compounds.

SSAs are produced by bursting bubbles at the sea surface (Woodcock, 1953; Pruppacher and Klett, 1997). We used the parameterization from Monahan et al. (1986) to estimate the flux of these particles (with wind speed $u=5 \mathrm{~m} \mathrm{~s}^{-1}$ ). The initial composition of SSAs is listed in Table 2. According to measurements made by Koop et al. (2000) SSAs and sulfate aerosols are liquid under the conditions of our model runs.

The very stiff chemical differential equation system is solved with a Rosenbrock thirdorder integrator using automatically adjusted timestep $\left(\Delta t=10^{-10}\right.$ to $\left.10 \mathrm{~s}\right)$ (Sandu et al., 1996).

The chemistry influencing ODEs

M. Piot and R. von

Glasow

Title Page

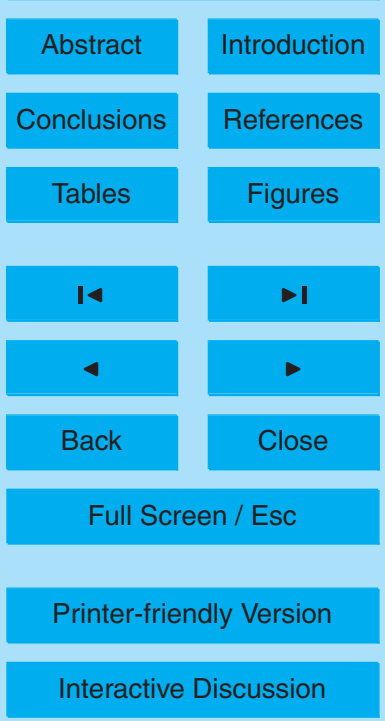

Interactive Discussion 
All chemical reactions in gas and aqueous phase, equilibria and transfer reactions are calculated as one coupled system using the kinetic preprocessor KPP which allows rapid change of the chemical mechanism (Damian et al., 2002). The temperature, humidity and particle size distribution are updated every $10 \mathrm{~s}$. Photolysis frequencies 5 are calculated online (Landgraf and Crutzen, 1998) every 10-min timestep with a fourstream model.

We used a two-day, one-dimensional model run to calculate the photolysis rates at the lowermost layer $(5 \mathrm{~m})$, used in the initialization of the box model. SSAs are produced during this "spinup" run. The box-model sensitivity runs last four days.

10 A diurnal variation of the temperature $(\Delta T=2 \mathrm{~K})$ is prescribed, inducing a temperature range from $\mathrm{T}=243.5$ to $245.5 \mathrm{~K}$ in the model (see Jobson et al., 1994; Hopper et al., 1994; Ridley et al., 2003).

The initial mixing ratios for gas phase species $(\xi)$ are based on observations made at Alert, in April (Table 3). MISTRA includes a comprehensive set of gas phase reac15 tions as well as chemical reactions in aerosol particles focusing on halogen species. Exchanges between the two phases are also taken into account. The set of used reactions is similar to von Glasow et al. (2002b), but updated with data from the IUPAC compilation (February 2006, available from http://www.iupac-kinetic.ch.cam.ac.uk/).

The chemical reaction mechanism in the model has been updated with additional relevant species for the Arctic environment: alkyl nitrate $\mathrm{RONO}_{2}$ (with the alkyl group $\mathrm{R}=\mathrm{C}_{\mathrm{n}} \mathrm{H}_{2 \mathrm{n}+1}$ ), bromoform $\mathrm{CHBr}_{3}$ and methyl bromide $\mathrm{CH}_{3} \mathrm{Br}$. The model includes 169 gas phase reactions ( $\mathrm{H}-\mathrm{O}-\mathrm{S}-\mathrm{C}-\mathrm{N}-\mathrm{Br}-\mathrm{Cl}$ ), as well as 150 aqueous phase reactions, 60 phase exchange reactions, 13 heterogeneous reactions and 21 equilibria for both sulfate and sea salt aerosols. The updated set of reactions is available as electronic attachment to this paper. http://www.atmos-chem-phys-discuss.net/8/7391/ 2008/acpd-8-7391-2008-supplement.pdf

All particles above their deliquescence humidity $(70 \%$ and $75 \%$ of relative humidity for sulfate and sea salt aerosols, respectively) are treated as aqueous solutions. The same holds for particles that had been activated or have been released as droplets

\section{The chemistry influencing ODEs}

M. Piot and R. von

Glasow

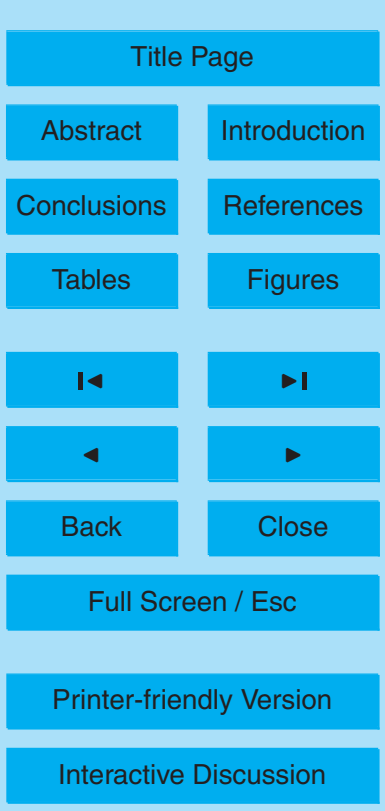


above their crystallisation humidity ( $40 \%$ and $42 \%$, respectively). A detailed description of the aerosol characteristics can be found in von Glasow et al. (2002b).

Under coastal conditions, we prescribed surface fluxes of dimethylsulfide (DMS) and ammonia $\left(\mathrm{NH}_{3}\right)$, as well as mixing ratios of biogenic bromine (see Table 1 ).

\section{Chemical reaction cycles}

This section is meant to give an introduction to reaction cycles that will be discussed in the remainder of this paper. For a more thorough discussion please refer to, e.g., Seinfeld and Pandis (1998) or Finlayson-Pitts and Pitts (1999).

\section{1 $\mathrm{HCHO}$ and $\mathrm{HO}_{\mathrm{x}}$ chemistry}

10 Formaldehyde $(\mathrm{HCHO})$ is an important source of oxidizing free radicals $\left(\mathrm{HO}_{\mathrm{x}}\right)$ for the $\mathrm{PBL}$, and has therefore received considerable interest in the last decade (Barrie et al., 1994; Sumner and Shepson, 1999; Hutterli et al., 2002; Jacobi et al., 2002; Ridley et al., 2003; Jacobi et al., 2004). Measurements in the air, firn air, and in snow revealed variations of $\mathrm{HCHO}$ determined by several processes. Its uptake/release between the snow and adjacent firn air is temperature-dependent. Additionally, photochemical reactions and ventilation of the firn air to the above layers play an important role in the production of $\mathrm{HCHO}$ from the snowpack. For more details on the production of $\mathrm{HCHO}$ the reader is referred to Simpson et al. (2007b). Its main loss reactions are:

$$
\mathrm{HCHO} \stackrel{h v}{\longrightarrow} \mathrm{H}_{2}+\mathrm{CO}
$$

$$
\stackrel{h v, \mathrm{O}_{2}}{\longrightarrow} 2 \mathrm{HO}_{2}+\mathrm{CO}
$$

$\mathrm{HCHO}+\mathrm{OH} \stackrel{\mathrm{O}_{2}}{\longrightarrow} \mathrm{HO}_{2}+\mathrm{CO}+\mathrm{H}_{2} \mathrm{O}$

If present in sufficient amounts, $\mathrm{HCHO}$ may modify the bromine chemistry via:

$\mathrm{HCHO}+\mathrm{BrO} \stackrel{\mathrm{O}_{2}}{\longrightarrow} \mathrm{HOBr}+\mathrm{CO}+\mathrm{HO}_{2}$

\section{ACPD}

$8,7391-7453,2008$

The chemistry influencing ODEs

M. Piot and R. von

Glasow

Title Page

Abstract

Introduction

Conclusions

References

Tables

Figures

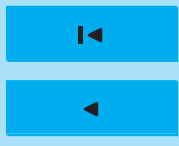

$\rightarrow$

Back

Close

Full Screen / Esc

Printer-friendly Version

Interactive Discussion

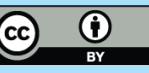




$$
\mathrm{HCHO}+\mathrm{Br} \stackrel{\mathrm{O}_{2}}{\longrightarrow} \mathrm{HBr}+\mathrm{CO}+\mathrm{HO}_{2}
$$

The reaction between $\mathrm{HCHO}$ and chlorine is discussed in Sect. 3.3. The chemistry of formaldehyde is investigated in Sect. 4.3.

Hydrogen peroxide $\left(\mathrm{H}_{2} \mathrm{O}_{2}\right)$ in the Arctic is found in high concentrations in snow. 5 Snow-air fluxes have been measured at several sites in polar regions (Fuhrer et al., 1996; Hutterli et al., 2001; Jacobi et al., 2002; Hutterli et al., 2004). It is reversibly deposited to the snow due to nonlinear processes occurring between the atmosphere and the snow (Conklin et al., 1993; Neftel et al., 1995). $\mathrm{H}_{2} \mathrm{O}_{2}$ has a significant impact on the lifetime of trace gases as it constitutes a large potential source for gas phase oxidants $\left(\mathrm{HO}_{\mathrm{x}}\right)$ which contribute to the atmospheric oxidizing capacity. $\mathrm{H}_{2} \mathrm{O}_{2}$ is destroyed in Reactions (20-22) (producing $\mathrm{HO}_{\mathrm{x}}$ ) and is produced in Reaction (23).

$$
\begin{aligned}
& \mathrm{H}_{2} \mathrm{O}_{2} \stackrel{h v}{\longrightarrow} 2 \mathrm{OH} \\
& \mathrm{H}_{2} \mathrm{O}_{2}+\mathrm{OH} \longrightarrow \mathrm{HO}_{2}+\mathrm{H}_{2} \mathrm{O} \\
& \mathrm{H}_{2} \mathrm{O}_{2}+\mathrm{Cl} \longrightarrow \mathrm{HCl}+\mathrm{HO}_{2} \\
& \mathrm{HO}_{2} \mathrm{HO}_{2}+\mathrm{HO}_{2} \longrightarrow \mathrm{H}_{2} \mathrm{O}_{2}+\mathrm{O}_{2}
\end{aligned}
$$

The chemistry of $\mathrm{H}_{2} \mathrm{O}_{2}$ is discussed in Sect. 4.4.

\subsection{DMS chemistry}

Charlson et al. (1987) suggested a role of dimethylsufilde (DMS) in regulating climate. This effect, if present, remains ill-quantified though. Toumi (1994), based on kinetic

data from Barnes et al. (1991), was the first to suggest that BrO might play an important role in the oxidation of DMS. von Glasow and Crutzen (2004) discussed uncertainties in the oxidation of DMS and pointed out that the net effect of DMS oxidation products, considering $\mathrm{BrO}$ as oxidant, on clouds might be contrary to those suggested by Charlson et al. (1987), namely a decrease of cloud albedo instead of an increase.

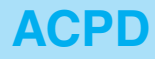

$8,7391-7453,2008$

The chemistry influencing ODEs

M. Piot and R. von

Glasow

Title Page

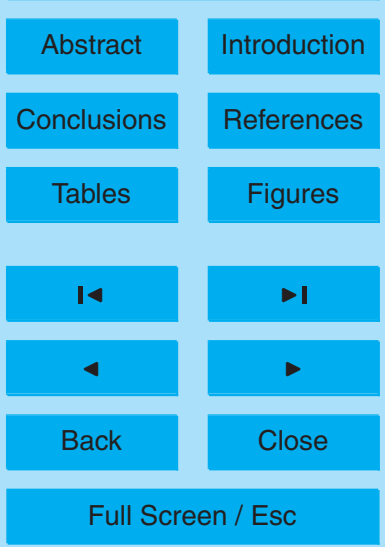

Printer-friendly Version

Interactive Discussion 
The following are the most important halogen-DMS reactions:

$$
\begin{aligned}
& \mathrm{DMS}+\mathrm{Cl} \stackrel{\mathrm{O}_{2}}{\longrightarrow} \mathrm{HCl}+\mathrm{CH}_{3} \mathrm{SCH}_{2} \mathrm{O}_{2} \\
& \mathrm{DMS}+\mathrm{BrO} \longrightarrow \mathrm{DMSO}+\mathrm{Br} \\
& \mathrm{DMSO}+\mathrm{OH} \longrightarrow 0.95 \mathrm{CH}_{3} \mathrm{O}_{2}+0.95 \mathrm{CH}_{3} \mathrm{SO}_{2} \mathrm{H} \\
&+0.05 \mathrm{DMSO}_{2}
\end{aligned}
$$

The interactions between DMS and bromine are discussed in Sect. 4.5.

\subsection{Chlorine chemistry}

The chemistry of chlorine has been extensively studied. Keene et al. (1999) provided an inventory for sources of reactive chlorine. Jobson et al. (1994) were the first to indirectly measure concentrations of chlorine in the Arctic troposphere.

However, low chlorine levels observed in the Arctic indicated its minor role in ozone depletions (Perner et al., 1999; Foster et al., 2001; Spicer et al., 2002). Nevertheless, chlorine may considerably modify hydrocarbons and radical budgets (Jobson et al., 1994; Ariya et al., 1998, 1999; Ramacher et al., 1999): the destruction of ozone by 15 chlorine chemistry is described in Sect. 1. Additionally, if substantial levels of chlorine are present the following reactions may become important:

$$
\begin{aligned}
\mathrm{Cl}+\mathrm{CH}_{4} \stackrel{\mathrm{O}_{2}}{\longrightarrow} \mathrm{HCl}+\mathrm{CH}_{3} \mathrm{O}_{2} \\
\mathrm{CH}_{3} \mathrm{O}_{2}+\mathrm{HO}_{2} \longrightarrow \mathrm{ROOH}+\mathrm{O}_{2} \\
\mathrm{ROOH}+\mathrm{Cl} \longrightarrow \mathrm{HCl}+\mathrm{CH}_{3} \mathrm{O}_{2} \\
20 \quad \mathrm{ClO}+\mathrm{CH}_{3} \mathrm{O}_{2} \longrightarrow \mathrm{Cl}+\mathrm{HCHO}+\mathrm{HO}_{2} \\
\mathrm{Cl}+\mathrm{HCHO} \stackrel{\mathrm{O}_{2}}{\longrightarrow} \mathrm{HCl}+\mathrm{HO}_{2}+\mathrm{CO}
\end{aligned}
$$

where $\mathrm{ROOH}$ is a hydroperoxide (see, e.g., Jacob, 2000; Frey et al., 2006) with $\mathrm{R}=\mathrm{C}_{n} \mathrm{H}_{2 n+1}$. Chlorine chemistry is investigated in Sect. 4.6.

The chemistry influencing ODEs

M. Piot and R. von

Glasow

Title Page

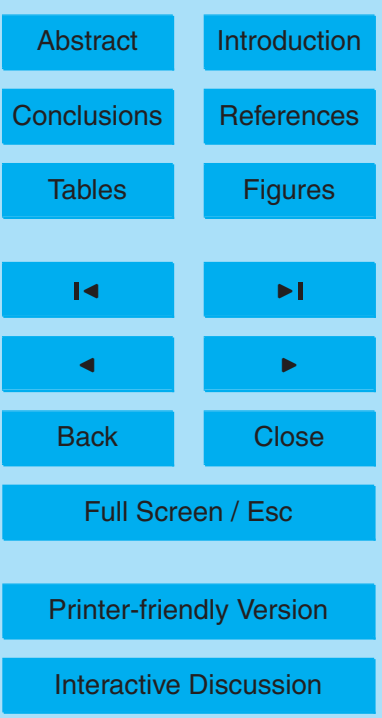




\section{$3.4 \quad \mathrm{C}_{2} \mathrm{H}_{4}$ chemistry}

Measurements of fluxes of alkenes from the snow have shown the presence of local sources for ethene $\left(\mathrm{C}_{2} \mathrm{H}_{4}\right)$ in the Arctic. Bottenheim et al. (2002a) measured atmospheric mixing ratios as high as $100 \mathrm{pmol} \mathrm{mol}^{-1}$ in early spring with a slow decrease 5 with season. In our set of reactions, three reactions characterize the chemistry of $\mathrm{C}_{2} \mathrm{H}_{4}$ :

$$
\begin{gathered}
\mathrm{C}_{2} \mathrm{H}_{4}+\mathrm{Cl} \stackrel{\mathrm{O}_{2}}{\longrightarrow} \mathrm{HCl}+\mathrm{C}_{2} \mathrm{H}_{5} \mathrm{O}_{2} \\
\mathrm{C}_{2} \mathrm{H}_{4}+\mathrm{OH} \stackrel{\mathrm{O}_{2}}{\longrightarrow} \mathrm{H}_{2} \mathrm{C}(\mathrm{OH}) \mathrm{CH}_{2} \mathrm{OO} \\
\mathrm{C}_{2} \mathrm{H}_{4}+\mathrm{Br} \stackrel{\mathrm{O}_{2}}{\longrightarrow} \mathrm{HBr}+\mathrm{C}_{2} \mathrm{H}_{5} \mathrm{O}_{2}
\end{gathered}
$$

The rate coefficients for Reactions (32) and (33) are about 200 and 2000 times 10 higher than for Reaction (34), respectively. The reactions involving $\mathrm{C}_{2} \mathrm{H}_{5} \mathrm{O}_{2}$ and $\mathrm{H}_{2} \mathrm{C}(\mathrm{OH}) \mathrm{CH}_{2} \mathrm{OO}$ will not be further detailed in this paper as their reaction rates remain very small under polar conditions. In MISTRA the possible formation of organicallybound bromine compounds as reaction product of Reaction (34) (Keil and Shepson, 2006) is not taken into account. Other reactions with heavier alkenes are not included in the model. We investigated the effect of these three reactions in Sect. 4.7.

\section{5 $\mathrm{C}_{2} \mathrm{H}_{6}$ chemistry}

Alkanes are commonly present in the Arctic due to transport from the source regions (Eurasia and northern America mostly, see AMAP report, 1998). In April, ethane $\left(\mathrm{C}_{2} \mathrm{H}_{6}\right)$ is usually observed in the surface air at about $1.5-2.5 \mathrm{nmol} \mathrm{mol}^{-1}$ with a gradual

decline with season (Jobson et al., 1994; Ariya et al., 1999; Bottenheim et al., 2002a; Evans et al., 2003). In our model $\mathrm{C}_{2} \mathrm{H}_{6}$ chemistry includes the following reactions:

$$
\begin{gathered}
\mathrm{C}_{2} \mathrm{H}_{6}+\mathrm{Cl} \stackrel{\mathrm{O}_{2}}{\longrightarrow} \mathrm{HCl}+\mathrm{C}_{2} \mathrm{H}_{5} \mathrm{O}_{2} \\
\mathrm{C}_{2} \mathrm{H}_{6}+\mathrm{OH} \stackrel{\mathrm{O}_{2}}{\longrightarrow} \mathrm{C}_{2} \mathrm{H}_{5} \mathrm{O}_{2}+\mathrm{H}_{2} \mathrm{O}
\end{gathered}
$$

The chemistry influencing ODEs

M. Piot and R. von

Glasow

Title Page

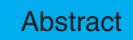

Introduction

Conclusions

References

Tables

Figures

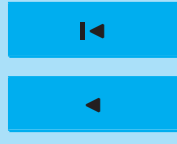

$\rightarrow 1$

Back

Close

Full Screen / Esc

Printer-friendly Version

Interactive Discussion 
$\mathrm{C}_{2} \mathrm{H}_{6}$ does not directly react with bromine. As for alkenes, heavier alkane compounds are not included in the model. The sensitivity studies on the influence of $\mathrm{C}_{2} \mathrm{H}_{6}$ on the ozone/halogen chemistry are presented in Sect. 4.8.

3.6 $\mathrm{NO}_{\mathrm{x}}$ chemistry

$5 \mathrm{NO}_{\mathrm{x}}$ species are photochemically produced in the snowpack (Honrath et al., 1999, 2000a,b; Zhou et al., 2001; Beine et al., 2002; Jacobi et al., 2004). The major $\mathrm{NO}_{\mathrm{x}}$ reactions are listed below.

\section{$8,7391-7453,2008$}

The chemistry influencing ODEs

M. Piot and R. von

Glasow

$$
\begin{aligned}
& \mathrm{NO}_{2} \stackrel{h \nu, \mathrm{O}_{2}}{\rightleftharpoons} \mathrm{NO}+\mathrm{O}_{3} \\
& \mathrm{NO}_{2}+\mathrm{OH} \stackrel{\mathrm{M}}{\longrightarrow} \mathrm{HNO}_{3} \\
& 10 \mathrm{NO}+\mathrm{HO}_{2} \longrightarrow \mathrm{NO}_{2}+\mathrm{OH}
\end{aligned}
$$

With sufficiently high $\mathrm{NO}_{\mathrm{x}}$ concentrations, the concentrations of bromine radicals may be altered via:

$$
\begin{aligned}
& \mathrm{Br}+\mathrm{NO}_{2} \longrightarrow \mathrm{BrNO}_{2} \\
& \mathrm{BrO}+\mathrm{NO}_{2} \stackrel{\mathrm{M}}{\rightleftharpoons} \mathrm{BrONO}_{2}
\end{aligned}
$$

After their formation, bromine nitrate and nitrite may decompose back or photolyze to release reactive bromine:

$$
\begin{aligned}
\mathrm{BrNO}_{2} \stackrel{h v}{\longrightarrow} \mathrm{Br}+\mathrm{NO}_{2} \\
\mathrm{BrONO}_{2} \stackrel{h v}{\longrightarrow} \mathrm{Br}+\mathrm{NO}_{3} \\
\mathrm{Br}+\mathrm{BrONO}_{2} \longrightarrow \mathrm{Br}_{2}+\mathrm{NO}_{3}
\end{aligned}
$$

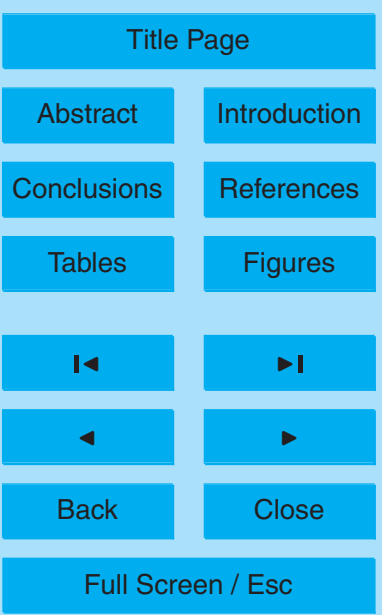

Printer-friendly Version

Interactive Discussion 
$\mathrm{BrONO}_{2}$ may also hydrolyse on liquid surfaces via:

$\mathrm{BrONO}_{2} \stackrel{\mathrm{H}_{2} \mathrm{O}}{\longrightarrow} \mathrm{HOBr}+\mathrm{HNO}_{3}$

Also, Sander et al. (1999) suggested that $\mathrm{BrONO}_{2}$ may heterogeneously react with aerosol halides without required acidity (based on experimental observations from

5 Behnke et al., 1997):

$\mathrm{BrONO}_{2}+\mathrm{X}_{\mathrm{aq}}^{-} \longrightarrow \mathrm{BrX}_{\mathrm{aq}}+\mathrm{NO}_{3, \mathrm{aq}}^{-} \longrightarrow \mathrm{BrX}$

However, in the Arctic, the release of reactive bromine under background $\mathrm{NO}_{x}$ levels via this reaction is relatively small (100 times less efficient than Reaction 14, due to a small rate coefficient for Reaction 47).

The chemistry of nitrous acid (HONO) plays an important role for the complete nitrogen cycle in the troposphere (Perner and Platt, 1979; Heikes and Thompson, 1983). Measurements in the Arctic during spring indicated intensive photochemical productions in the snowpack constituting a major source of HONO for the boundary layer (Zhou et al., 2001; Beine et al., 2003; Amoroso et al., 2006). The only relevant sink for $\mathrm{HONO}$ is its photolysis producing both highly reactive $\mathrm{OH}$ and $\mathrm{NO}$ molecules:

$\mathrm{HONO} \stackrel{h v}{\longrightarrow} \mathrm{OH}+\mathrm{NO}$

$\mathrm{RONO}_{2}$ is likely to contribute to the $\mathrm{NO}_{\mathrm{x}}$ budget (Brasseur et al., 1999). For a detailed description of the production and loss of $\mathrm{RONO}_{2}$, see Carter and Atkinson (1985). In the Arctic $\mathrm{RONO}_{2}$ mainly reacts via the following reactions:

$$
\begin{aligned}
\mathrm{RONO}_{2} & \stackrel{h v}{\longrightarrow} \mathrm{NO}_{2}+\text { products } \\
\mathrm{RONO}_{2}+\mathrm{OH} & \longrightarrow \mathrm{HNO}_{3}+\text { products } \\
\mathrm{RONO}_{2}+\mathrm{Cl} & \longrightarrow \mathrm{HCl}+\mathrm{NO}_{2}+\text { products }
\end{aligned}
$$

The chemistry of the $\mathrm{NO}_{y}$ species $\left(\mathrm{NO}_{\mathrm{x}}, \mathrm{HONO}\right.$, and $\left.\mathrm{RONO}_{2}\right)$ is investigated in Sect. 4.9.

The chemistry influencing ODEs

M. Piot and R. von

Glasow

Title Page

Abstract

Introduction

Conclusions

Tables

References

Figures

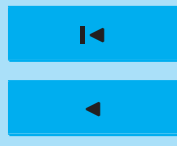

$>1$

Back

Close

Full Screen / Esc

Printer-friendly Version

Interactive Discussion 


\section{Discussion of the sensitivity studies}

\subsection{Overview}

We prescribed a source of gas phase halogens to reproduce ozone depletions with observed time scales. In this paper, for the sake of simplicity, we did not intend to re5 alistically reproduce the source of bromine in the model. For a thorough investigation of the source of bromine, the reader is referred to the recent paper from Piot and von Glasow (2007). We quantified the required fluxes of halogen in accordance with their effects on ozone. Then, we associated the resulting ozone depletions with the classification proposed by Ridley et al. (2003) to define the type of ODE. Regarding ozone 10 mixing ratios, we define a partial ODE (PODE) as $4<\xi_{\text {Ozone }} \leq 20 \mathrm{nmol} \mathrm{mol}^{-1}$ and a major ODE (MODE) as $\xi_{\text {Ozone }} \leq 4 \mathrm{nmol} \mathrm{mol}^{-1}$. We distinguished major ODEs developing within one day from major ODEs developing within four days (called M1 and M4). Partial ODEs developing within 4 days are named $\mathrm{P} 4$. Depletions of ozone are reproduced via different sources of halogens. In this study, we analyzed $\mathrm{Br}_{2}, \mathrm{Cl}_{2}$ and $\mathrm{BrCl}$ as the

15 potential sources. Note that no diurnal variation of fluxes is taken into account in this study. The applied source of halogens is prescribed as a constant flux (see Table 4).

Excessive fluxes of chlorine are discussed in Sect. 4.6.

The runs including a prescribed source of halogens and initialized as shown in Table 3 represent our "base runs". Figure 2 illustrates the M1, M4 and P4 ODEs caused by the prescribed $\mathrm{Br}_{2}$ fluxes (Table 4). The names of our sensitivity runs include the source of halogens $\left(\mathrm{Br}_{2}, \mathrm{BrCl}\right.$, or $\left.\mathrm{Cl}_{2}\right)$ and additionally any change compared to the base run. The run $\mathrm{Br}_{2}-\mathrm{M} 4$ is one of our base runs with a major ozone depletion developing within four days caused by a $\mathrm{Br}_{2}$ flux. The run $\mathrm{Br}_{2}-\mathrm{M} 4-\mathrm{DMS}=0.20 \mathrm{nmol} \mathrm{mol}^{-1}$ is the same run with a different value for the initial mixing ratio of DMS than in the base 25 run.

Our sensitivity studies consist of modifying the amount of a species compared to the amount in the base runs. We want to stress that only relevant cases with infor-

\section{The chemistry} influencing ODEs

M. Piot and R. von

Glasow

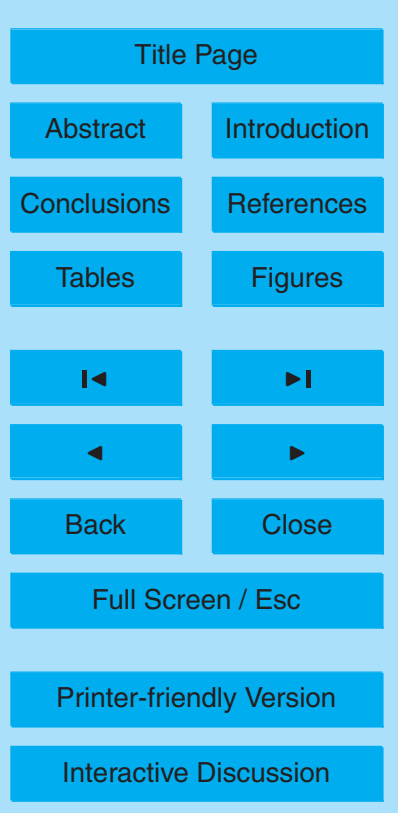

res 
mative features for halogen or ozone concentrations are discussed in this paper. This paper does not intend to reproduce observed conditions, but rather to investigate the potential influence of several species on the halogen/ozone chemistry. We differentiate three different modification types: a change in initial mixing ratio only, in flux only, or in 5 both. The studied values, for mixing ratios, were increased/decreased by an order of magnitude compared to the initial value used in the base runs. In case flux measurements for a species are known, we used an adequate average value for our sensitivity tests (e.g., see Sect. 4.9). When no flux measurement is known at the appropriate location and time of the year, we assumed the fluxes as function of their initial mixing 10 ratio. After evaluation of the potential range of study, lower/upper values for the fluxes in these sensitivity studies are chosen to be $10 \% / 200 \%$ of the initial mixing ratio, per day (e.g., $\xi_{\text {ethane }}=1.5 \mathrm{nmol} \mathrm{mol}^{-1}$; flux $=0.15 / 3.0 \mathrm{nmol} \mathrm{mol}^{-1}$ day $^{-1}$ ). We chose $200 \%$ for the upper limit in our study as higher values would induce fluxes in majority exceeding any field observation. The value $10 \%$ induced small fluxes which do not considerably 5 modify the gas phase mixing ratio.

These fluxes remain constant throughout the model simulations. Diurnal variations that may be observed in the field (Sumner and Shepson, 1999; Zhou et al., 2001; Hutterli et al., 2001; Foster et al., 2001; Bottenheim et al., 2002a) are therefore not taken into account.

Due to the large number of sensitivity runs we only selected the most relevant runs in this paper. We chose the runs to be discussed with an ODE type (M1, M4, P4), based on the relevance of the applied conditions or their specific chemistry compared to the base run.

\subsection{Details of base runs}

25 In order to comprehensively analyze the sensitivity runs, we first describe the main features of the base runs. In Fig. 2, $\mathrm{O}_{3}$ undergoing a P4 ODE or a M4 ODE is continuously depleted, with a net slow down in destruction at night due to the absence of reactive halogens. The destruction of $\mathrm{O}_{3}$ during a $\mathrm{M} 1$ is very rapid and occurs within

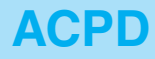

$8,7391-7453,2008$

\section{The chemistry} influencing ODEs

M. Piot and R. von

Glasow

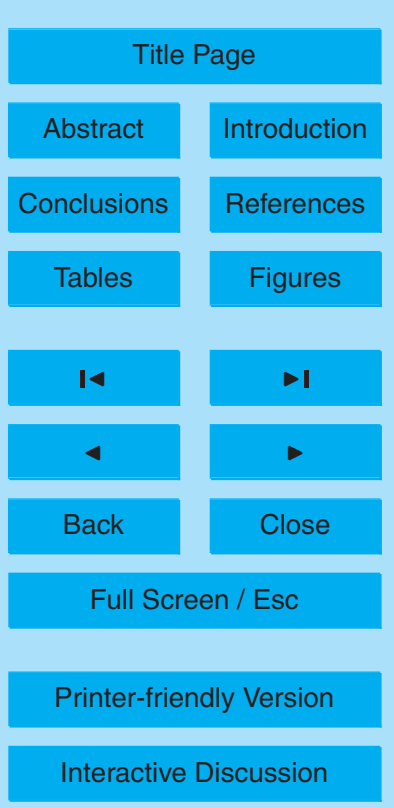


a few hours. In Fig. 3, we show the chemistry of compounds other than $\mathrm{O}_{3}$ for the two base runs $\mathrm{Br}_{2}-\mathrm{M} 4$ and $\mathrm{Br}_{2}-\mathrm{P} 4$. $\mathrm{Br}_{2}-\mathrm{M} 1$ is omitted for clarity. In addition, the base run $\mathrm{Br}_{2}-\mathrm{M} 1$ will not be investigated in great details in this paper as the required flux is rather unlikely high. Similarly, details of $\mathrm{BrCl}$ - and $\mathrm{Cl}_{2}$-induced ODEs will be described 5 in upcoming sections.

In both M4 and P4 cases, total gas phase bromine ( $\mathrm{Br}_{\mathrm{x}}$, Fig. $\left.3 \mathrm{a}\right)$ increases during the three first simulated days due to the constant flux of $\mathrm{Br}_{2}$. The production of $\mathrm{BrO}$ via Reaction (1) increases gradually over time. BrO undergoes a strong diurnal cycle (Fig. 3b) as Br atoms are quasi absent at night. Sea salt aerosol $\mathrm{Br}^{-}$is liberated in both 10 cases via the bromine explosion cycle (Fig. 3c) and less reactive bromine is mostly recycled via reaction in acidic sulfate aerosols (not shown). On the last simulated day bromine compounds evolve differently in cases M4 and P4: in the case $\mathrm{P} 4, \mathrm{O}_{3}$ remains above $11 \mathrm{nmol} \mathrm{mol}^{-1}$, and the rates for Reaction (1) do not decrease strongly due to the reduction of $\mathrm{O}_{3}$ mixing ratios. Therefore, $\mathrm{BrO}$ remains at high mixing ratios during 15 the last day $\left(\sim 25 \mathrm{pmol} \mathrm{mol}^{-1}\right)$. In contrast, in the case $\mathrm{M} 4$, the $\mathrm{O}_{3}$ destruction is nearly complete $12 \mathrm{~h}$ before the end of the run. Rates for Reaction (1) drastically decrease and the $\mathrm{BrO}$ production is also reduced (see sharp decrease in Fig. 3b). The decrease of this reaction rate leads to a shift in speciation from $\mathrm{BrO}$ to $\mathrm{Br}$, and therefore, from $\mathrm{HOBr}$ to $\mathrm{HBr}$ (see Reactions 5 and 13). The reduction of $\mathrm{HOBr}$ and increase of $\mathrm{HBr}$ lead to 20 the re-bromination of the aerosols (see SSA Br${ }^{-}$in Fig. 3c, on the last day. Sulfate $\mathrm{Br}^{-}$ not shown). $\mathrm{HO}_{\mathrm{x}}$ mixing ratios on the first day are approximately 1 and $1.5 \mathrm{pmol} \mathrm{mol}^{-1}$ in cases M4 and P4, respectively, with a rapid decrease to values below $0.3 \mathrm{pmol} \mathrm{mol}^{-1}$ for the following days. These mixing ratios are similar to measurements obtained by Bloss et al. (2007) in coastal Antarctica.

\subsection{Formaldehyde influence}

We investigated the influence of a constant flux of $\mathrm{HCHO}$ on the development of an ODE. Figure 4 shows the comparison between the base run $\mathrm{Br}_{2}-\mathrm{P} 4$ and the run $\mathrm{Br}_{2}$ -

\section{The chemistry influencing ODEs}

M. Piot and R. von

Glasow

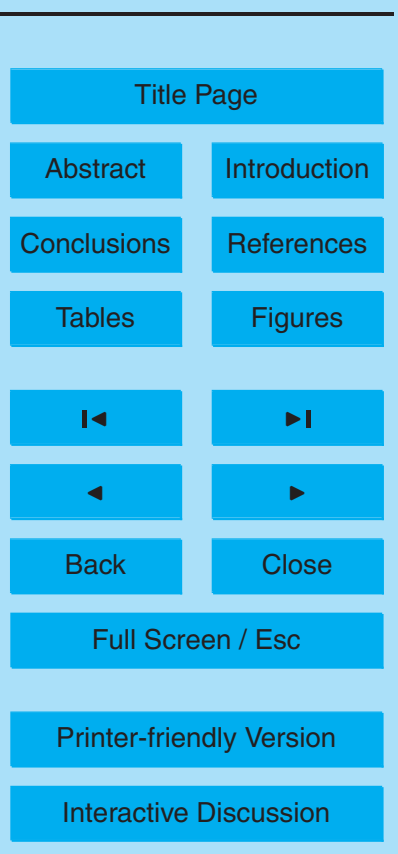


$\mathrm{P} 4-\mathrm{HCHO}$ where a flux of $5.0 \times 10^{9}$ molec $\mathrm{cm}^{-2} \mathrm{~s}^{-1}$ is prescribed under background air conditions (for these conditions, see Table 1). This value is similar to the one used in Michalowski et al. (2000), and the resulting $\mathrm{HCHO}$ mixing ratios in the gas phase are in good agreement with observations (de Serves, 1994; Sumner and Shepson, 1999;

5 Sumner et al., 2002). As explained in Sect. 3.1 a high concentration of HCHO (Fig. 4b) increases the reaction rates of Reactions (18) and (19) and increases the production of $\mathrm{HO}_{2}$ via Reactions (16) and (17) (Fig. 4c). Therefore, in this case the halogen speciation is rapidly shifted from $X$ and $X O$ to $H O X$ and $H X$ (also see Reactions 5 and 13). Mixing ratios of $\mathrm{HBr}, \mathrm{HCl}, \mathrm{HOBr}$, and $\mathrm{HOCl}$ rapidly increase (Figs. $4 \mathrm{~g}$ to i). The 10 uptake of these compounds onto aerosols maintains the rapid aerosol dehalogenation via the bromine explosion process (Reaction 14, see Fig. 4d).

The sea salt aerosol dehalogenation depends on the ratio $\left[\mathrm{Br}^{-}\right]:\left[\mathrm{Cl}^{-}\right]$(see Fickert et al., 1999; Adams et al., 2002). Under our conditions, this dehalogenation occurs mostly in the form of $\mathrm{Br}_{2}$ liberation in the gas phase, but $\mathrm{BrCl}$ and $\mathrm{Cl}_{2}$ are also 5 produced.

After the near-complete aerosol debromination on the first day (after $\simeq 10 \mathrm{~h}$ ), both runs undergo a shift in speciation from bromine radicals to $\mathrm{HOBr}$ and $\mathrm{HBr}$ (shift stronger in $\mathrm{Br}_{2}-\mathrm{P} 4-\mathrm{HCHO}$ ). This shift reduces the $\mathrm{BrO}$ self-reaction (Reactions 2-3) which is an efficient cycle for the release of $\mathrm{Br}$ atoms. Furthermore, bromine deposition on snow 20 strongly increases (see accumulated deposition in Fig. 4k), significantly decreasing the total gas phase bromine concentration in Fig. $4 \mathrm{j}$. We calculated that $\mathrm{HOBr}$ is responsible for nearly $80 \%$ of this increase.

Interestingly, mixing ratios of $\mathrm{Br}_{2}$ in the gas phase (Fig. 4f) show a decrease compared to the base run. This decrease is a consequence of the large loss of bromine on snow which reduces the bromine loading in the gas phase.

At the end of the model run the amount of highly reactive $\mathrm{BrO}$ is reduced by $65 \%$ (Fig. $4 \mathrm{e}$ ). As a result $\mathrm{O}_{3}$ mixing ratios are $10 \mathrm{nmol} \mathrm{mol}^{-1}$ higher than in the base run (Fig. $4 \mathrm{a}$ ). Note that $\mathrm{Br}^{-}$in SSA increases during the last simulated day in the base run due to insufficient $\mathrm{HOBr}$ in the aqueous phase (see solid black line, Fig. 4d).

\section{The chemistry} influencing ODEs

M. Piot and R. von

Glasow

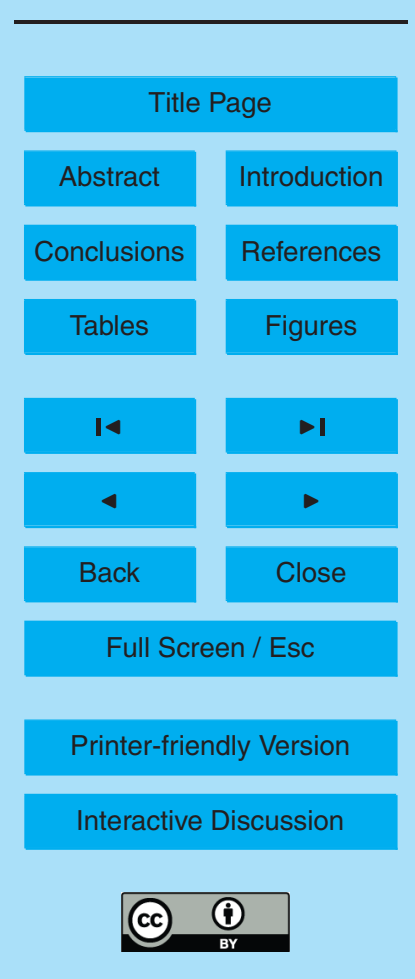


In summary, a flux of $\mathrm{HCHO}$ as prescribed here efficiently reduces the ozone depletion process, as the PODE4 threshold is reached only at the very end of the simulation.

In all studied cases with elevated $\mathrm{HCHO}$ mixing ratios, $\mathrm{HCHO}$ strongly modified the halogen speciation. However, the conditions of high mixing ratios of $\mathrm{HCHO}$ differ5 ently impacted the ozone chemistry, depending on the concentration of $\mathrm{Br}^{-}$in sea salt aerosols. With high initial aerosol $\mathrm{Br}^{-}$concentrations, the bromine explosion is accelerated by the presence of more $\mathrm{HCHO}$ and $\mathrm{HO}_{x}$ (see explanations above). With very low initial $\mathrm{Br}^{-}$concentrations, the chemistry is characterized only by the shift in bromine speciation and a resulting reduction of available highly reactive bromine radicals (not 10 shown).

Under conditions of near-total $\mathrm{O}_{3}$ depletion and high concentrations of $\mathrm{HCHO}$ in the air (e.g., $\mathrm{Br}_{2}-\mathrm{M} 1$ with a constant flux of $\mathrm{HCHO}$ ), the conversion from bromine radicals to $\mathrm{HBr}$ and $\mathrm{HOBr}$ rapidly leads to an increase in aerosol $\mathrm{Br}^{-}$concentration and therefore, in its deposition on snow. Mixing ratios of $\mathrm{Br}_{\mathrm{x}}$ dramatically decrease (not shown). We 15 noted no major difference in the chemistry when we applied this case to coastal air conditions (with the changes listed in Table 1).

Under conditions of $\mathrm{Cl}_{2}$-induced ODEs, the presence of high $\mathrm{HCHO}$ fluxes led to no relevant changes in the ozone chemistry (maximum differences of $1 \mathrm{nmol} \mathrm{mol}^{-1}$ ).

When prescribing a $\mathrm{HCHO}$ flux of $6.0 \times 10^{7}$ molec $\mathrm{cm}^{-2} \mathrm{~s}^{-1}$, as estimated from Jacobi 20 et al. (2002) (see Piot and von Glasow, 2007), the influence on bromine was negligigle. We conclude that this flux of $\mathrm{HCHO}$ has insignificant effects on ozone. These sensitivity studies show that higher fluxes of $\mathrm{HCHO}$ possibly causing the observed gas phase concentrations are required to significantly impact the ozone chemistry.

\section{$4.4 \quad \mathrm{H}_{2} \mathrm{O}_{2}$}

25 In this section we compare the base run $\mathrm{Br}_{2}-\mathrm{M} 4$ to $\mathrm{Br}_{2}-\mathrm{M} 4-$ $\mathrm{H}_{2} \mathrm{O}_{2}=1.5 \times 10^{10}$ molec cm ${ }^{-2} \mathrm{~s}^{-1}$ (Fig. 5). To the best of our knowledge, fluxes of $\mathrm{H}_{2} \mathrm{O}_{2}$ at Alert in spring have not yet been measured. Therefore, we used values for

\section{The chemistry influencing ODEs}

M. Piot and R. von

Glasow

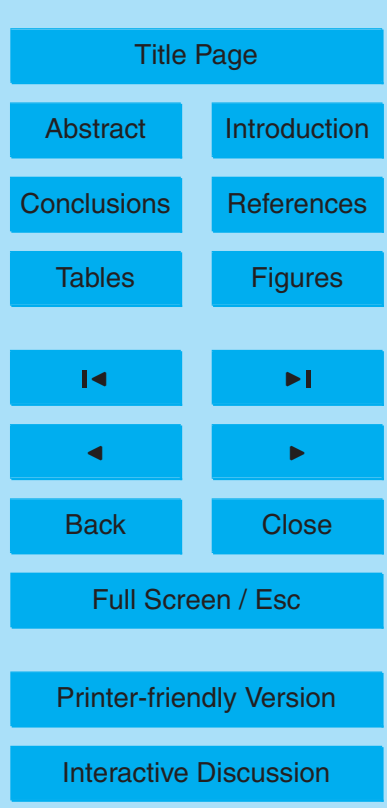


this flux as described in Sect. 4.1. Such fluxes out of the snowpack have already been measured by Hutterli et al. (2004), but their location (Summit, Greenland) and the period of measurement (summer) differ significantly from our conditions. This $\mathrm{H}_{2} \mathrm{O}_{2}$ flux induces gas phase mixing ratios three to four times higher than observations in the

5 Arctic spring (de Serves, 1994). However, these mixing ratios remain in the range of late spring/summertime measurements (Bales et al., 1995; Hutterli et al., 2001; Jacobi et al., 2002).

The photolysis of $\mathrm{H}_{2} \mathrm{O}_{2}$ represents its primary loss pathway (Reaction 20), producing highly reactive $\mathrm{OH}$ radicals (Fig. 5d). Reactions (7) and (21) mainly increase the 10 concentration of $\mathrm{HO}_{2}$ (Fig. 5c). Therefore, as explained in Sect. 4.3, higher reaction rates for Reaction (5) and (13) lead to lower mixing ratios of $\mathrm{Br}$ and $\mathrm{BrO}$ (Fig. 5f). The higher mixing ratios of reaction products $\mathrm{HOBr}$ (Fig. 5e) and $\mathrm{HBr}$ maintain an efficient recycling in SSAs (Fig. 5g). Again, the shifted speciation from $\mathrm{Br} / \mathrm{BrO}$ to $\mathrm{HBr} / \mathrm{HOBr}$ reduces the efficiency of the $\mathrm{BrO}$ self-reaction, and the increase in bromine deposition 15 reduces the total amount of gas phase bromine. Mixing ratios of $\mathrm{BrO}$ decrease by up to $10 \mathrm{pmol} \mathrm{mol}^{-1}$ between day 2 and 3 compared to the base run $\mathrm{Br}_{2}-\mathrm{M} 4$. (Fig. $5 \mathrm{f}$ ). Consequently, mixing ratios of $\mathrm{O}_{3}$ are about $9 \mathrm{nmol} \mathrm{mol}^{-1}$ higher than in the base run after three days. On the last simulated day, $\mathrm{O}_{3}$ mixing ratios reach the $\mathrm{M} 4$ threshold with a 12-hour delay compared to the base run. As the ozone depletion is not complete on this last simulated day, $\mathrm{BrO}$ mixing ratios remain high, while they rapidly decrease in the base run $\mathrm{Br}_{2}-\mathrm{M} 4$ (see Fig. 5f). Similarly, the bromine recycling through the aerosol phase remains efficient, keeping $\mathrm{Br}^{-}$concentrations low (Fig. $5 \mathrm{~g}$ ), while the base run undergoes a re-bromination (see Sect. 4.2).

This flux of $\mathrm{H}_{2} \mathrm{O}_{2}$ substantially affected the ozone destruction. The aerosol debromi25 nation remained more efficient than in the base model run. However, the deposition of bromine on snow (more than $2.0 \times 10^{-7} \mathrm{~mol} \mathrm{~m}^{-2}$ compared to $0.4 \times 10^{-7}$ for the base run) was higher than the bromine production in the gas phase and it strongly reduced the amount of reactive bromine.

When prescribing a flux of $1.0 \times 10^{8}$ molec $\mathrm{cm}^{-2} \mathrm{~s}^{-1}$, estimated from Jacobi et al.

\section{The chemistry influencing ODEs}

M. Piot and R. von

Glasow

Title Page

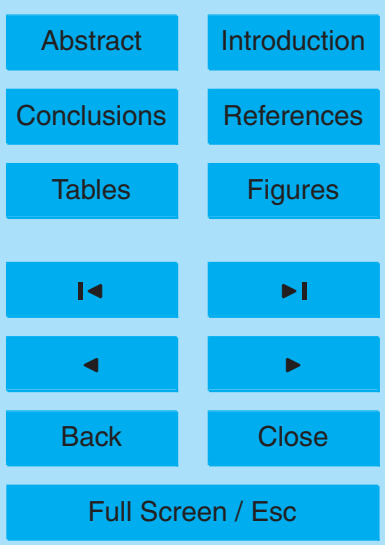

Printer-friendly Version

Interactive Discussion 
(2002) (see Piot and von Glasow, 2007) for early spring, the ozone chemistry showed no major change. Such a value for the $\mathrm{H}_{2} \mathrm{O}_{2}$ flux does not substantially affect the concentration of $\mathrm{HO}_{x}$ in the gas phase. It seems, from these results, that the fluxes of $\mathrm{H}_{2} \mathrm{O}_{2}$ estimated for the high Arctic in spring are not significantly influencing the ozone 5 chemistry. These sensitivity studies showed that only higher fluxes (most probably related to higher temperatures, e.g., in late spring/summer, see Hutterli et al., 2001) may effectively influence the ozone/halogen chemistry.

\subsection{DMS and DMSO "counter-cycle"}

To the best of our knowledge, fluxes of DMS have not been measured in the Arctic spring. The value for the flux used in this section is explained in Sect. 4.1. Figure 6 shows a comparison between the base run $\mathrm{Br}_{2}-\mathrm{M} 4$ and the model run $\mathrm{Br}_{2}-\mathrm{M} 4-$ DMS $=100 \mathrm{pmol} \mathrm{mol}^{-1}$ with a flux of $4.0 \times 10^{9} \mathrm{molec}^{-2} \mathrm{~s}^{-1}$. We investigated DMS only under coastal conditions as it is produced in the ocean.

The primary effect of high concentrations of DMS on the ozone/halogen chemistry is 15 through Reaction (25): BrO oxidizes DMS and produces $\mathrm{Br}$ radicals which represents an efficient additional recycling pathway for $\mathrm{BrO}$. Indeed, this reaction leads to slightly more ozone depletion during the first simulated day (about $0.7 \%$ ). The reaction product DMSO (Fig. 6c) then reacts with $\mathrm{OH}$ (Reaction 26) to produce $\mathrm{CH}_{3} \mathrm{O}_{2}$ (Fig. 6d). This represents a key reaction initiating a cycle that we call the DMSO "counter-cycle" (see Fig. 7). An increase in $\mathrm{CH}_{3} \mathrm{O}_{2}$ induces more $\mathrm{HCHO}$ (Fig. 6e) and $\mathrm{HO}_{2}$ which eventually affect the bromine distribution. This leads, again, to a shift in bromine speciation as explained in Sects. 4.3 and 4.4. Note that the increase of $\mathrm{CH}_{3} \mathrm{O}_{2}$ and $\mathrm{HCHO}$ starts on the first simulated day, while the bromine speciation shift becomes important only on the following day. The relative variation of $\mathrm{BrO}$ compared to the base run is anticorrelated to the relative variations of $\mathrm{HOBr}$ and $\mathrm{HBr}$. The presence of more $\mathrm{HOBr}$ and $\mathrm{HBr}$ in the gas phase (Figs. $6 \mathrm{~h}$ and i) accelerates the aerosol debromination (see Fig. 6k). However, the deposition of (mostly) HOBr represents a great sink for bromine (Fig. $6 \mathrm{l}$ ). $\mathrm{Br}_{\mathrm{x}}$ is only slightly affected by the competition between aerosol debromination

The chemistry influencing ODEs

M. Piot and R. von

Glasow

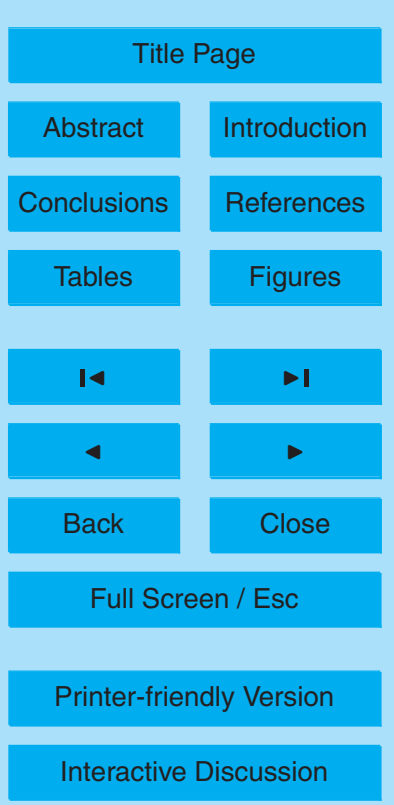


acceleration enhancing $\xi_{\mathrm{Br}_{\mathrm{x}}}$ and the increase of bromine deposition decreasing $\xi_{\mathrm{Br}_{\mathrm{x}}}$ (Fig. 6j). In this run, ozone reaches the M4 threshold with a delay of only two hours.

In summary, contrary to what one might have expected the reaction between DMS and $\mathrm{BrO}$ is not dominating the overall effect of DMS on bromine/ozone under the con5 ditions of this run. The production of $\mathrm{CH}_{3} \mathrm{O}_{2}$ via reaction between DMSO and $\mathrm{OH}$ becomes rapidly important and leads to less $\mathrm{Br}$ radicals. Under conditions of near-total ozone destruction (e.g., run $\mathrm{Br}_{2}-\mathrm{M} 1$ after the first day), the shift in bromine speciation from $\mathrm{BrO}$ and $\mathrm{Br}$ to mostly $\mathrm{HBr}$ leads to a efficient bromination and re-bromination of sulfate and sea salt aerosols, respectively (not shown).

10 DMS does not react substantially with $\mathrm{ClO}$ and the rate coefficient of Reaction (24) is very small. Therefore, DMS does not have an effect on $\mathrm{Cl}_{2}$-induced ODEs.

\section{6 $\mathrm{Cl}_{2}$ and "chlorine counter-cycle"}

All previous ODEs we investigated were induced by $\mathrm{B}_{2}$ flux. In this section we present results on $\mathrm{Cl}_{2}$-induced ODEs (see Table 4) to study the influence of a $\mathrm{Cl}_{2}$ flux on ozone chemistry. Not surprisingly, the prescribed $\mathrm{Cl}_{2}$ fluxes required to reduce $\mathrm{O}_{3}$ within the observed time scales were unrealistically high. Nevertheless, we describe these sensitivity runs as they appear interesting for a better understanding of the chemical cycles.

We present in Fig. 8 the base run $\mathrm{Cl}_{2}-\mathrm{M} 1$. Upon photolysis of $\mathrm{Cl}_{2}$ on the first simu20 lated day, the two main reactions using chlorine (Reactions 1 and 27) lead to a strong production of $\mathrm{ClO}$ and $\mathrm{CH}_{3} \mathrm{O}_{2}$ (see Fig. 8). Those two reaction products react together to yield $\mathrm{HCHO}$ (Reaction 30 ). This reaction, increasing $\mathrm{HCHO}$ mixing ratios (Fig. 8), also accelerates the reaction rate of Reaction (31). This reaction chain efficiently converts $\mathrm{Cl} / \mathrm{ClO}$ (see $\mathrm{HCl}$ compared to the sharp decreases in $\mathrm{Cl} / \mathrm{ClO}$ a few hours after each sunrise in Fig. 8). Additionally, $\mathrm{ROOH}$ is produced substantially via Reaction (28) due to the high concentrations of $\mathrm{CH}_{3} \mathrm{O}_{2}$ and $\mathrm{HO}_{2}$. Thus, the reaction rate of Reaction (29) also increases and contributes to the rise of $\mathrm{HCl}$ mixing ratios. All these reaction pathways are schematically described in Fig. 9. This figure clearly shows that

The chemistry influencing ODEs

M. Piot and R. von

Glasow

Title Page

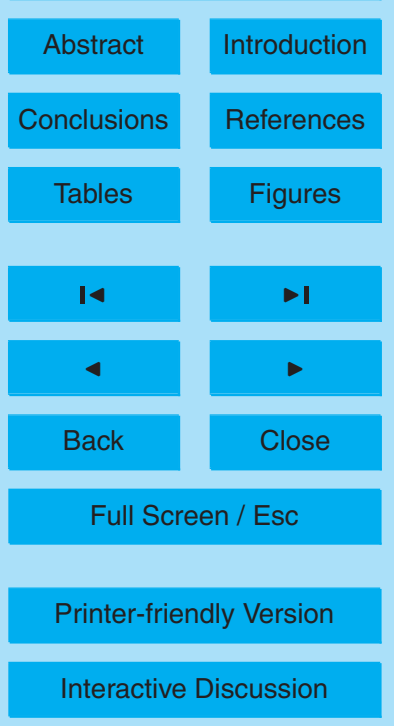


the reaction chain initiated by Reaction (27) efficiently induces a direct (Reactions 27, 29 , and 31 ) or indirect (Reactions 28 and 30) conversion from reactive chlorine to less reactive $\mathrm{HCl}$. $\mathrm{HCl}$ drastically increases to reach unrealistically high mixing ratios of several tens of $\mathrm{nmol} \mathrm{mol}{ }^{-1}$.

5 In summary, $\mathrm{Cl}$ and $\mathrm{ClO}$ radicals rapidly react to produce compounds $\left(\mathrm{HO}_{\mathrm{x}}, \mathrm{ROOH}\right.$ or $\mathrm{CH}_{3} \mathrm{O}_{2}$ ) which eventually react back with $\mathrm{Cl} / \mathrm{ClO}$ to release $\mathrm{HCl}$. We call this negative feedback "chlorine counter-cycle".

As highlighted in this section, a higher flux of chlorine radicals induces an even stronger "chlorine counter-cycle", shifting chlorine to $\mathrm{HCl}$. In order to induce a major 10 ODE within one day (M1), it is necessary to prescribe an unrealistically high $\mathrm{Cl}_{2}$ flux of $3.0 \times 10^{11}$ molec $\mathrm{cm}^{-2} \mathrm{~s}^{-1}$ to keep the reaction between $\mathrm{Cl}$ and $\mathrm{O}_{3}$ (Reaction 1) efficient. Mixing ratios of $\mathrm{ClO}$ (up to $1 \mathrm{nmol} \mathrm{mol}^{-1}$ ) and $\mathrm{Cl}$ (order of pmol mol${ }^{-1}$ ) are inconsistent with measurements made in the Arctic (Tuckermann et al., 1997; Impey et al., 1997; Perner et al., 1999; Boudries and Bottenheim, 2000). We conclude that the presence of this efficient "chlorine counter-cycle", as explained in this section, makes a $\mathrm{Cl}_{2}$-induced ODE unrealistic.

This counter-cycle cannot initiate in case of $\mathrm{Br}_{2}$-induced ODEs, as there is no reaction between bromine atom and $\mathrm{CH}_{4}$, which is the key reaction to yield $\mathrm{CH}_{3} \mathrm{O}_{2}$ in case of $\mathrm{Cl}_{2}$-induced ODEs.

20 It is noteworthy mentioning the effect of this counter-cycle on $\mathrm{Br}_{2}$-induced ODEs including high concentrations of chlorine. In our sensitivity studies this counter-cycle appeared to have a substantial influence on the eventual ozone mixing ratios in several runs. As an example, Fig. 10 shows the comparison between the base run $\mathrm{Br}_{2}-\mathrm{M} 4$ and $\mathrm{Br}_{2}-\mathrm{M} 4-\mathrm{Cl}_{2}=5.0 \times 10^{8}$ molec $\mathrm{cm}^{-2} \mathrm{~s}^{-1}$ under coastal air conditions. In this case $\mathrm{Cl}$ concentrations of up to $2.5 \times 10^{-3} \mathrm{pmol} \mathrm{mol}^{-1}$ released via $\mathrm{Cl}_{2}$ photolysis is sufficiently high to "activate" the counter-cycle and therefore, slow down the ozone destruction via reduction of $\mathrm{BrO}$ and $\mathrm{Br}$. After the sunrise on the first day, mixing ratios of $\mathrm{ClO}$ rapidly rise to a maximum of $7 \mathrm{pmol} \mathrm{mol}^{-1}$ (Fig. 10b) mostly via Reaction (1). This contributes to the slight decrease in $\mathrm{O}_{3}$ on the first day compared to the base run

The chemistry influencing ODEs

M. Piot and R. von

Glasow

Title Page

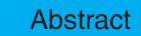

Conclusions

Tables

References

Figures

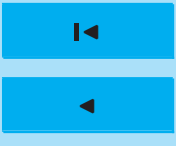

$\rightarrow 1$

Back

Close

Full Screen / Esc

Printer-friendly Version

Interactive Discussion 
(Fig. 10a). As highlighted in this section, the high mixing ratios of $\mathrm{Cl}$ and $\mathrm{ClO}$ lead to the activation of the chlorine counter-cycle: $\mathrm{CH}_{3} \mathrm{O}_{2}, \mathrm{HO}_{x}$, and $\mathrm{ROOH}$ substantially increase (see Figs. 10d and e). Several hours after each sunrise of the model run, chlorine radicals undergo the sharp decrease attributed to the counter-cycle (see Fig. 10b with 5 mean values similar to observations from Perner et al., 1999; Tuckermann et al., 1997) and are converted to unreactive $\mathrm{HCl}$ (Fig. 10c). As a consequence, higher mixing ratios of $\mathrm{CH}_{3} \mathrm{O}_{2}$ increase reaction rates of Reactions (11-12), while reaction rates of Reactions (5, 13, 18 and 19) are higher due to increased $\mathrm{HO}_{2}$ and $\mathrm{HCHO}$ (see Fig. 10e). Again, bromine undergoes a shift in speciation from $\mathrm{Br} / \mathrm{BrO}$ to $\mathrm{HBr} / \mathrm{HOBr}$ 10 (Figs. 10f to h).

This case highlights that high concentrations of bromine together with chlorine may lead to unexpected halogen interactions. The eventual effect on ozone depends on the activation state of the chlorine counter-cycle.

The chemistry of $\mathrm{BrCl}$-induced ODEs is similar to that of $\mathrm{B}_{2}$-induced ODE includ15 ing a flux of chlorine. In the P4 ozone destruction, the release of chlorine via the flux of $\mathrm{BrCl}\left(1.0 \times 10^{8}\right.$ molec $\mathrm{cm}^{-2} \mathrm{~s}^{-1}$, see Table 4$)$ is too small to "activate" the chlorine counter-cycle. The bromine chemistry in the $\mathrm{BrCl}-\mathrm{P} 4$ case remains nearly identical to the chemistry described for the base run $\mathrm{Br}_{2}-\mathrm{P} 4$. Therefore, the required flux for $\mathrm{BrCl}$ to induce an equivalent $\mathrm{P} 4$ as for $\mathrm{Br}_{2}-\mathrm{P} 4$ is stochiometrically similar to the $\mathrm{Br}_{2}$ flux. Such

20 a flux of $\mathrm{BrCl}$ induces realistic loadings of chlorine in the model: $\xi_{\mathrm{ClO}} \sim 2 \mathrm{pmol} \mathrm{mol}^{-1}$ (see Perner et al., 1999), $\xi_{\mathrm{Cl}} \sim 4 \times 10^{-4} \mathrm{pmol} \mathrm{mol}^{-1}$ (see Jobson et al., 1994; Boudries and Bottenheim, 2000), and $\xi_{\mathrm{Cl}_{2}} \sim 2$ pmol mol${ }^{-1}$ (see Foster et al., 2001). The BrCl-M4 base run does show a small influence of the counter-cycle on the bromine chemistry. This can be highlighted by increased concentrations of $\mathrm{HBr}$ compared to the concen25 trations in $\mathrm{Br}_{2}-\mathrm{M} 4$ (increase of about $40 \%$ ). Therefore, the $\mathrm{BrCl}$ flux required to induce an equivalent M4 ODE as in the $\mathrm{Br}_{2}$ case is slightly higher than the stochiometric ratio with $\mathrm{Br}_{2}\left(1.9 \times 10^{8}\right.$ compared to $2 \times 9.0 \times 10^{7}$ molec $\left.\mathrm{cm}^{-2} \mathrm{~s}^{-1}\right)$. In addition, loadings of chlorine in the model do not differ substantially from the $\mathrm{BrCl}-\mathrm{P} 4$ run. Mixing ratios of $\mathrm{BrCl}$ in $\mathrm{BrCl}-\mathrm{M} 4$ reach $7 \mathrm{pmol} \mathrm{mol}^{-1}$, while they have a maximum of $5 \mathrm{pmol} \mathrm{mol}^{-1}$

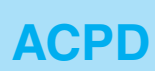

$8,7391-7453,2008$

\section{The chemistry influencing ODEs}

M. Piot and R. von

Glasow

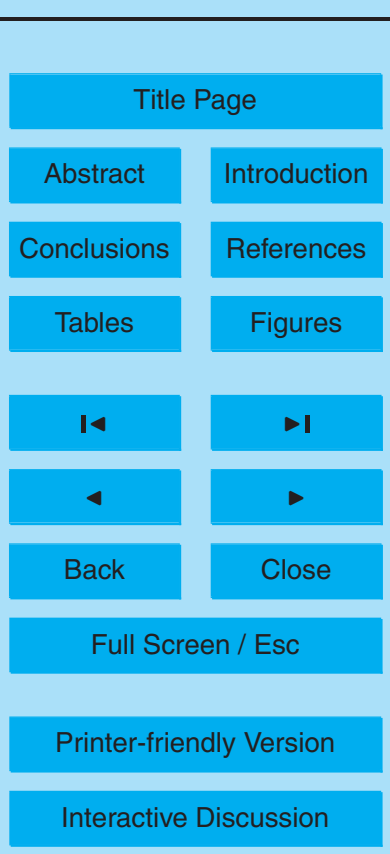


in $\mathrm{BrCl}-\mathrm{P} 4$. In the $\mathrm{BrCl}-\mathrm{M} 1$ base run, the chlorine counter-cycle is clearly activated and it strongly affects the bromine chemistry by shifting reactive bromine to mainly $\mathrm{HBr}$ (10 to 20 times higher in $\mathrm{BrCl}$ - than $\mathrm{Br}_{2}$-induced ODEs, not consistent with predictions from other models, see Fan and Jacob, 1992; Sander et al., 1997; Lehrer et al., 5 2004). BrCl mixing ratios reach a maximum of $38 \mathrm{pmol} \mathrm{mol}^{-1}$ which is a rather high value compared to measurements made by Foster et al. (2001). The required flux of $\mathrm{BrCl}$, compared to $\mathrm{Br}_{2}$, is substantially higher than the stochiometric ratio $\left(3.4 \times 10^{9}\right.$ compared to $2 \times 1.5 \times 10^{9}$ molec $\mathrm{cm}^{-2} \mathrm{~s}^{-1}$ ), showing that the chlorine counter-cycle is activated. These studies show that only the chemistry of the $\mathrm{BrCl}-\mathrm{P} 4$ and $\mathrm{BrCl}-\mathrm{M} 4$ runs lies within the range of observations.

\section{$4.7 \quad \mathrm{C}_{2} \mathrm{H}_{4}$}

Ethene $\left(\mathrm{C}_{2} \mathrm{H}_{4}\right)$ chemistry is characterized by the three reactions listed in Sect. 3.4. In this section we compare the base run $\mathrm{Br}_{2}-\mathrm{M} 4$ with $\mathrm{Br}_{2}-\mathrm{M} 4-\mathrm{C}_{2} \mathrm{H}_{4}=0.8 \mathrm{nmol} \mathrm{mol}{ }^{-1}$ under coastal conditions (Fig. 11). Such a high mixing ratio for $\mathrm{C}_{2} \mathrm{H}_{4}$ corresponds to an upper 15 limit, but this value lies within the variability of observations during Arctic spring (Doskey and Gaffney, 1992; Ariya et al., 1999).

Mixing ratios of $\mathrm{OH}$ (Fig. 11c) and $\mathrm{Cl}$ (released from SSA; Fig. 11d) decrease, but the $\mathrm{Cl}$ chemistry does not affect the ozone/bromine concentration under these conditions ( $\xi_{\mathrm{Cl}}$ too low, but similar to measurements from Jobson et al., 1994; Boudries and Bottenheim, 2000). The increase in $\xi_{\mathrm{C}_{2} \mathrm{H}_{4}}$ reduces $\mathrm{HO}_{\mathrm{x}}$ lifetime via Reaction (33).

Therefore, this reaction tends to reduce the formation of $\mathrm{HOBr}$ from $\mathrm{Br} / \mathrm{BrO}$ radicals. However, in the case of $\mathrm{Br}_{2}-\mathrm{M} 4-\mathrm{C}_{2} \mathrm{H}_{4}=0.8 \mathrm{nmol} \mathrm{mol}{ }^{-1}$ Reaction (34) is accelerated (see Fig. 11e). This reaction prevails over Reactions (32) and (33) during the whole model run and increases the formation of $\mathrm{HBr}$. Thus, $\mathrm{BrO}$ mixing ratios decrease strongly (Fig. 11i). Clearly, the decrease of $\mathrm{HOBr}$ (Fig. 11g) reduces the efficiency of the bromine explosion mechanism and the shift of bromine speciation to $\mathrm{HBr}$ and its subsequent uptake to particles leads to a drastic increase in sulfate and sea

\section{The chemistry} influencing ODEs

M. Piot and R. von

Glasow

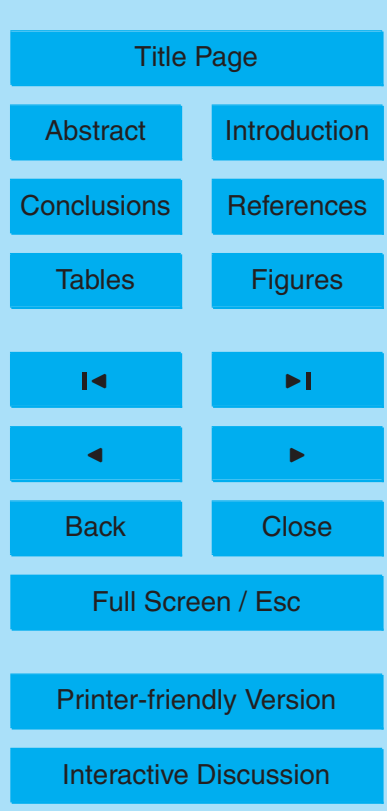


salt aerosol $\mathrm{Br}^{-}$(Fig. 11h, not shown for sulfate aerosols). $\mathrm{Br}^{-}$concentrations in SSA are up to $20 \mathrm{mmoll}^{-1}$ higher than in the base run $\mathrm{Br}_{2}-\mathrm{M} 4$. This scenario shows that the presence of large amounts of $\mathrm{C}_{2} \mathrm{H}_{4}$ notably reduces the efficiency of the bromine explosion. This and the conversion from $\mathrm{Br}$ atoms to less reactive $\mathrm{HBr}$ lead to less 5 available bromine radicals for the depletion of ozone. The ozone mixing ratio drops only to $11 \mathrm{nmol} \mathrm{mol}{ }^{-1}$ within four days, which is equivalent to a "P4" event.

However, it is important to note that the $\mathrm{C}_{2} \mathrm{H}_{4}$ destruction reactions may compete with each other, depending on the amount of $\mathrm{C}_{2} \mathrm{H}_{4}$ in the model run. In order to assess the influence of Reaction (33) compared to Reaction (34), we performed additional 10 model runs with $\xi_{\mathrm{C}_{2} \mathrm{H}_{4}}=0.5$ and $0.01 \mathrm{nmol} \mathrm{mol}^{-1}$. In Fig. 12, we compare ozone mixing ratios of the different runs with ozone in $(\mathrm{A}) \mathrm{Br}_{2}-\mathrm{M} 4$ and $(\mathrm{B}) \mathrm{Br}_{2}-\mathrm{P} 4$. In Fig. 12a, these ratios for $\mathrm{C}_{2} \mathrm{H}_{4}=0.8$ and $\mathrm{C}_{2} \mathrm{H}_{4}=0.5 \mathrm{nmol} \mathrm{mol}^{-1}$ show that ozone for these runs is less depleted than for the base run, due to the reduction in the bromine explosion cycle, as explained above. Interestingly, however, ozone is also temporarily less depleted 15 than in the base run under conditions of $\xi_{\mathrm{C}_{2} \mathrm{H}_{4}}=0.01 \mathrm{nmol} \mathrm{mol}{ }^{-1}$ (less $\mathrm{C}_{2} \mathrm{H}_{4}$ than in the base run). With low $\xi_{\mathrm{C}_{2} \mathrm{H}_{4}}$ the reduced rate of Reaction (33) allows more $\mathrm{HO}_{\mathrm{x}}$ to react with bromine radicals to form $\mathrm{HOBr}$. Similarly, a reduction in the rate of Reaction (34) leads to less $\mathrm{HBr}$. The increase and slight decrease of $\mathrm{HOBr}$ and $\mathrm{HBr}$, respectively, induce a moderate acceleration of the SSA debromination compared to the base run. 20 Nevertheless, as highlighted in previous sections, the formation of $\mathrm{HOBr}$ reduces $\mathrm{Br}_{\mathrm{x}}$ via increased deposition at the surface.

As a consequence, less bromine radicals are available compared to the base run. The difference to the base run M4 is highest in the morning of day 3 . Later, ozone rapidly decreases and becomes more depleted than in the base run M4. This change 25 in ozone destruction is the result of a large decrease in reaction rate of Reaction (34). At the end of the model run $\mathrm{Br}_{2}-\mathrm{M} 4-\mathrm{C}_{2} \mathrm{H}_{4}=0.01 \mathrm{nmol} \mathrm{mol}^{-1}, \mathrm{C}_{2} \mathrm{H}_{4}$ is completely destroyed. Therefore, the concentration of $\mathrm{Br}$ atoms increases compared to the base run, which leads to a more efficient ODE on the last day. This specific time span highlights the importance of Reaction (34) in reducing the amount of available $\mathrm{Br}$ atoms, although

\section{The chemistry influencing ODEs}

M. Piot and R. von

Glasow

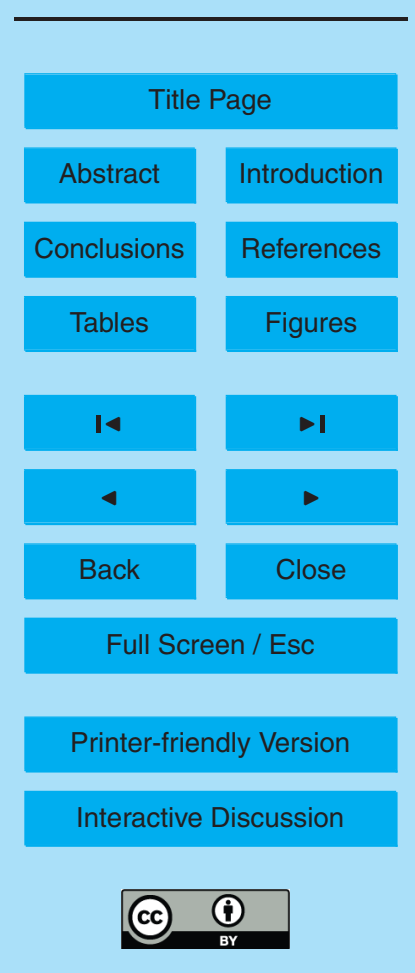


the rate coefficient for this reaction is small.

Under conditions of a P4 ODE, an increase of $\xi_{\mathrm{C}_{2} \mathrm{H}_{4}}$ compared to $0.08 \mathrm{nmol} \mathrm{mol}^{-1}$ (base run $\mathrm{Br}_{2}-\mathrm{P} 4$ ) leads, again, to a decrease in ozone depletion via the reduction of the bromine explosion and the conversion from $\mathrm{Br}$ atoms to $\mathrm{HBr}$ (see Fig. 12b). The 5 model run with $\xi_{\mathrm{C}_{2} \mathrm{H}_{4}}=0.01 \mathrm{nmol} \mathrm{mol}^{-1}$ displays a similar chemistry as explained for the case $\mathrm{Br}_{2}-\mathrm{M} 4$. However, $\mathrm{C}_{2} \mathrm{H}_{4}$ does not drop down to zero at the end of the run as in $\mathrm{Br}_{2}-\mathrm{M} 4-\mathrm{C}_{2} \mathrm{H}_{4}=0.01 \mathrm{nmol} \mathrm{mol}^{-1}$. Therefore, Reaction (34) remains efficient during the whole model run. Ozone mixing ratios at the end of the model run (Fig. 12b) remain slightly higher than in the base run P4.

10 This study highlighted that high concentrations of ethene strongly reduced the bromine explosion and therefore, the ozone depletion. Low concentrations of ethene, however, allow substantial amounts of $\mathrm{HO}_{\mathrm{x}}$ to be present in the atmosphere, which shifts reactive bromine to less reactive $\mathrm{HOBr}$. Such concentrations may then lead to a decrease in ozone destruction as well.

Prescribing a flux of $1.3 \times 10^{8}$ molec $\mathrm{cm}^{-2} \mathrm{~s}^{-1}$ of $\mathrm{C}_{2} \mathrm{H}_{4}$, as measured by Swanson et al. (2002), showed only a very weak influence on ozone: $\xi_{\mathrm{O}_{3}}$ only increased by less than $1 \mathrm{nmol} \mathrm{mol}{ }^{-1}$. Fluxes measured in the field seem to have no noticeable influence on the bromine/ozone chemistry, but notice that the resulting $\mathrm{C}_{2} \mathrm{H}_{4}$ mixing ratios in the model only increases by $10 \mathrm{pmol} \mathrm{mol}^{-1}$ due to this prescribed flux. Only higher fluxes of $\mathrm{C}_{2} \mathrm{H}_{4}$ may affect the halogen/ozone chemistry.

\section{$4.8 \quad \mathrm{C}_{2} \mathrm{H}_{6}$}

First, we will discuss sensitivity studies on $\mathrm{Br}_{2}$-induced ODEs. The observed variability of $\mathrm{C}_{2} \mathrm{H}_{6}$ in the Arctic is relatively small (between 1 and $4 \mathrm{nmol} \mathrm{mol}^{-1}$, see Ariya et al., 1999). When investigating realistic values for $\mathrm{C}_{2} \mathrm{H}_{6}$ mixing ratios, we noted no relevant change in ozone. For a better understanding of the $\mathrm{C}_{2} \mathrm{H}_{6}$ chemistry, we also investigated the effects of higher mixing ratios (an order of magnitude higher than observed values, with $\xi_{\mathrm{C}_{2} \mathrm{H}_{6}}=15 \mathrm{nmol} \mathrm{mol}^{-1}$, see Table 3).

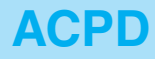

$8,7391-7453,2008$

The chemistry influencing ODEs

M. Piot and R. von

Glasow

Title Page

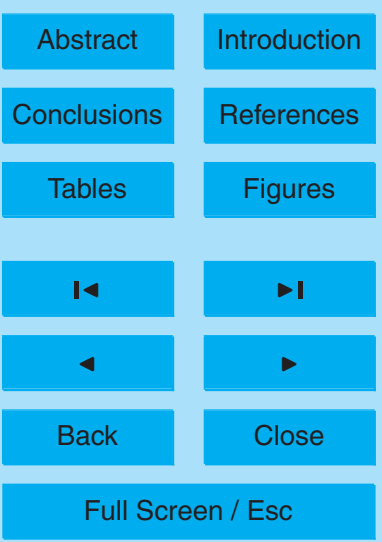

Printer-friendly Version

Interactive Discussion 
We compare now the base run $\mathrm{Br}_{2}-\mathrm{M} 4$ with $\mathrm{Br}_{2}-\mathrm{M} 4-\mathrm{C}_{2} \mathrm{H}_{6}=15 \mathrm{nmol} \mathrm{mol}{ }^{-1}$ under background conditions (Fig. 13). In our model $\mathrm{C}_{2} \mathrm{H}_{6}$ only reacts with $\mathrm{OH}$ and $\mathrm{Cl}$ with a rate coefficient for Reaction (35) approximately 500 times higher than for Reaction (36). Under $\mathrm{Br}_{2}-\mathrm{M} 4$ conditions, however, the concentration of $\mathrm{Cl}$ is very low: Reaction (35) 5 is negligible compared to Reaction (36). The removal of $\mathrm{OH}$ radicals from the atmosphere by $\mathrm{C}_{2} \mathrm{H}_{6}$ (Reaction 36) is an important pathway reducing the concentration of $\mathrm{HO}_{\mathrm{x}}$ (Fig. 13c and d) as well as $\mathrm{HCHO}$ (Fig. 13e). As explained in previous sections this decrease in oxidant concentrations reduces the production of $\mathrm{HOBr}$ and $\mathrm{HBr}$ (see Fig. 13g) and slows the bromine explosion cycle down. In this investigation, the limitation in $\mathrm{HO}_{x}$ prevails and increases the mixing ratio of $\mathrm{BrO}$ by at most $2 \mathrm{pmol} \mathrm{mol}^{-1}$ (Fig. 13f). The more efficient BrO self-reaction leads to a faster recycling of bromine oxide and a stronger ozone destruction (with a maximum decrease of $2 \mathrm{nmol} \mathrm{mol}^{-1}$ compared to the base model run, Fig. 13a). ODEs caused by $\mathrm{Br}_{2}$ emissions are enhanced under high concentrations of ethane. Ethane cleanses the air from high reactive oxidants which hinder the $\mathrm{BrO}$ self-reaction. However, relatively high mixing ratios of ethane do not substantially affect the ozone chemistry.

We also investigated $\mathrm{Cl}_{2}$-induced ODEs with increased mixing ratios of $\mathrm{C}_{2} \mathrm{H}_{6}$. In all ODE cases (M1, M4 and P4), Reaction (35) prevailed and induced weaker depletions of ozone. $\mathrm{C}_{2} \mathrm{H}_{6}$ effectively diminishes the availability of $\mathrm{Cl}$ atoms. Therefore, $\mathrm{C}_{2} \mathrm{H}_{6}$ directly reduces the chlorine-induced ozone destruction chain. By prescribing $15 \mathrm{nmol} \mathrm{mol}^{-1}$ of $\mathrm{C}_{2} \mathrm{H}_{6}$ compared to $1.5 \mathrm{nmol} \mathrm{mol}^{-1}$ in the base runs, ozone only reached the M2 threshold compared to $\mathrm{Cl}_{2}-\mathrm{M} 1, \mathrm{P} 4$ compared to $\mathrm{Cl}_{2}-\mathrm{M} 4$, and no ODE compared to $\mathrm{Cl}_{2}-\mathrm{P} 4$, respectively.

This study shows that ethane is mainly important for chlorine-related chemistry via direct reaction between $\mathrm{C}_{2} \mathrm{H}_{6}$ and $\mathrm{Cl}$. Ethane does not influence the bromine chemistry markedly: only reaction with $\mathrm{OH}$ radicals slightly reduces $\mathrm{HO}_{x}$ concentrations.

The chemistry influencing ODEs

M. Piot and R. von

Glasow

Title Page

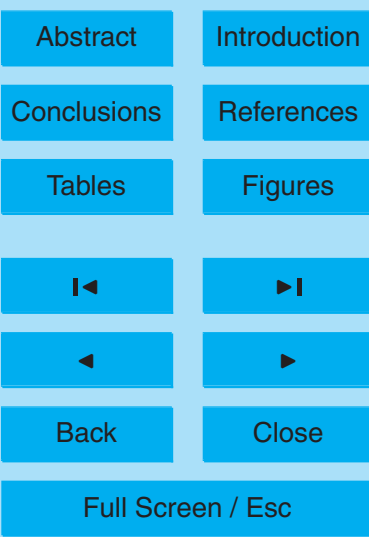

Printer-friendly Version

Interactive Discussion 
Field measurements in the Arctic spring have highlighted the production of HONO molecules originating from the snowpack. Zhou et al. (2001) measured hourlyaveraged HONO flux in the range of $0-1.0 \times 10^{9}$ molec $\mathrm{cm}^{-2} \mathrm{~s}^{-1}$ with a mean value 5 of $5.0 \times 10^{8}$ molec $\mathrm{cm}^{-2} \mathrm{~s}^{-1}$. In this section we investigate the importance of this mean value for the flux of HONO. Figure 14 shows the comparison between $\mathrm{Br}_{2}-\mathrm{P} 4$ and $\mathrm{Br}_{2}-\mathrm{P} 4-\mathrm{HONO}=5.0 \times 10^{8}$ molec $\mathrm{cm}^{-2} \mathrm{~s}^{-1}$ under background air conditions. At daytime, photolysis is the dominant loss for HONO (Reaction 48). OH (Fig. 14c) and NO (see Fig. 14e) radicals are rapidly produced.

10 As described earlier in this paper higher mixing ratios of $\mathrm{OH}$ induce a stronger production of $\mathrm{HO}_{2}$ (mostly via Reaction 7 , Fig. 14d). The presence of higher mixing ratios of $\mathrm{HO}_{2}$ compared to the base run leads to a shift in bromine speciation from $\mathrm{Br} / \mathrm{BrO}$ to $\mathrm{HBr} / \mathrm{HOBr}$ (Figs. 14h and i). Again, as described earlier, such $\mathrm{HOBr}$ mixing ratios accelerate the aerosol debromination via the bromine explosion (Fig. 14j), but its deposition on snow also substantially reduces the amount of available bromine. Furthermore, the production of $\mathrm{HOBr}$ in the case of $\mathrm{Br}_{2}-\mathrm{P} 4-\mathrm{HONO}=5.0 \times 10^{8}$ molec $\mathrm{cm}^{-2} \mathrm{~s}^{-1}$ induces a slow down in the rapid $\mathrm{BrO}$ self-reaction. These reactions contribute to the reduction of available highly reactive bromine (Fig. $14 \mathrm{~g}$ ) for the ozone depletion.

In addition, $\mathrm{NO}_{\mathrm{x}}$ production from the photolysis of $\mathrm{HONO}$ accelerates the rates of 20 Reactions (40) to (47). Reaction (42) accelerates the $\mathrm{BrO}$ recycling into $\mathrm{Br}$ atoms. However, Reactions (40) and (41) rapidly produce $\mathrm{BrNO}_{2}$ and $\mathrm{BrONO}_{2}$ during daytime, with $\mathrm{BrONO}_{2}$ reaching maxima of about $2 \mathrm{pmol} \mathrm{mol}^{-1}$ (not shown). $\mathrm{BrONO}_{2}$, more reactive than $\mathrm{BrNO}_{2}$, may heterogeneously react with aerosol surfaces to convert halides into photolysable halogens (Reaction 47). However, the aerosol debromination induced by this reaction pathway is about two orders of magnitude smaller than via Reaction (14). Indeed, $\mathrm{BrNO}_{2}$ and $\mathrm{BrONO}_{2}$ rather represent a temporary gas phase reservoir of bromine. In this model run, deposition of $\mathrm{BrONO}_{2}$ was found important for the loss of bromine on the snow. We calculated that the total bromine deposition

The chemistry influencing ODEs

M. Piot and R. von

Glasow

Title Page

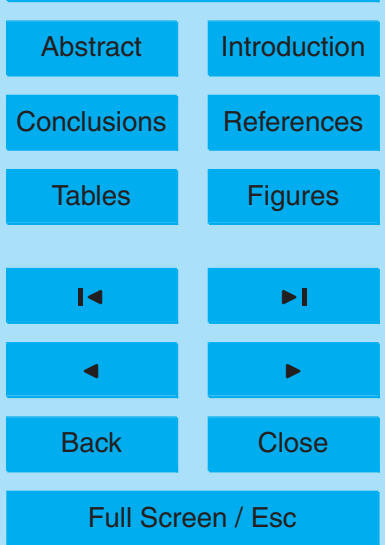

Printer-friendly Version

Interactive Discussion 
contributed, at the end of the model run, more than $30 \%$ to the total amount of bromine in the run compared to $10 \%$ for the base run (not shown). Bromine deposition on snow is higher than the bromine release from the bromine explosion. $\mathrm{Br}_{\mathrm{x}}$ mixing ratios decrease (Fig. 14f) and reduce the availability of reactive bromine (Fig. 14g). Conse5 quently, $\mathrm{O}_{3}$ is destroyed less and displays a final mixing ratio of $16.5 \mathrm{nmol} \mathrm{mol}^{-1}$ after the four simulated days compared to 12.0 for $\mathrm{Br}_{2}-\mathrm{P} 4$ (Fig. 14a).

Under conditions of the prescribed flux of HONO from the snow, maximum $\mathrm{NO}_{\mathrm{x}}$ mixing ratios remain near $2 \mathrm{pmol} \mathrm{mol}^{-1}$, as opposed to undetectable values in the base run $\mathrm{Br}_{2}-\mathrm{P} 4$ (see Fig. $14 \mathrm{e}$ after the first simulated day). The flux of HONO induced a moderate acid displacement in SSAs (see Robbins et al., 1959). The presence of $\mathrm{NO}_{x}$ leads to the production of $\mathrm{HNO}_{3}$ throughout the model run (via mainly Reaction 38, Fig. 14k). The uptake of this strong acid in SSAs induces an increase in acidity $\left(\mathrm{H}^{+}\right)$ and $\mathrm{NO}_{3}^{-}$ions. In our model run with a $\mathrm{HONO}$ flux, the SSA $\mathrm{H}^{+}$concentration is 5 to 10 times higher than in the base run, which modifies the equilibrium of reaction $\mathrm{H}^{+}+\mathrm{Cl}^{-}$ $15 \leftrightarrow \mathrm{HCl}_{\mathrm{aq}}$ to the right. Therefore, the uptake of $\mathrm{HNO}_{3}$ leads to the outgassing of $\mathrm{HCl}$.

Gas phase $\mathrm{HCl}$ chemistry is, however, driven at daytime by the increased release of $\mathrm{Cl}_{2}$ and $\mathrm{BrCl}$ in the gas phase compared to $\mathrm{Br}_{2}$ (Fig. 14I), as the equilibrium for Reaction (14) is also modified.

At night the absence of $\mathrm{OH}$ radicals stops the production of $\mathrm{HNO}_{3}$ via Reaction (38). 20 Therefore, the acid displacement in SSA is interrupted as well and $\mathrm{HCl}_{\text {gas }}$ is taken up into aerosols. $\mathrm{HCl}$ reaches a maximum of $16 \mathrm{pmol} \mathrm{mol}^{-1}$ at the end of the model run (Fig. 14I) and SSA chloride displays a net decrease over the model run (not shown).

These model results indicate that concentrations of $\mathrm{NO}_{x}$, under the influence of such a flux of HONO in Arctic regions, may be associated with high concentrations of gas phase chlorine, if chloride is present in aerosols (also see Hara et al., 2002). We encourage field experiments to find evidences for this specific chemistry in order to confirm these results.

Under coastal air conditions, the presence of high mixing ratios of $\mathrm{HOBr}$ and $\mathrm{BrONO}_{2}$ with a higher number of SSAs containing $\mathrm{Br}^{-}$(due to the SSA production) induces more

\section{The chemistry influencing ODEs}

M. Piot and R. von

Glasow

Title Page

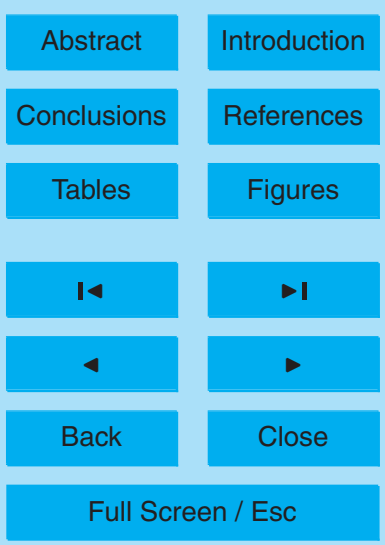

Printer-friendly Version

Interactive Discussion 
aerosol debromination. These conditions imply more $\mathrm{Br}_{\mathrm{x}}$ in the air during the model run than under background conditions. After four days, $\mathrm{O}_{3}$ is about $2.5 \mathrm{nmol} \mathrm{mol}^{-1}$ more depleted under coastal air than under background air conditions.

We also performed runs with lower/higher initial mixing ratios of $\mathrm{NO}_{2}$ (not shown).

5 The related chemistry was similar to that of HONO. Prescribing higher initial mixing ratios of $\mathrm{NO}_{2}$ mainly induced a shift in speciation from $\mathrm{Br} / \mathrm{BrO}$ to $\mathrm{BrNO}{ }_{2} / \mathrm{BrONO}_{2}$. This represents a reservoir of less reactive bromine, which reduces the amount of available reactive bromine. Additionally, accumulated bromine deposition increases, mostly due to higher deposition rate of $\mathrm{HOBr}$ and $\mathrm{BrONO}_{2}$. Ozone is less depleted in all studied cases that include more $\mathrm{NO}_{2}$ in the air. However, the difference in $\mathrm{O}_{3}$ mixing ratios compared to the base runs is rather small (nearly between 1 and $4 \mathrm{nmol} \mathrm{mol}^{-1}$ for maximum $\xi_{\mathrm{NO}_{2}}=0.2 \mathrm{nmol} \mathrm{mol}{ }^{-1}$ ). Acid displacement occurred in all cases as well.

We also studied the influence of higher mixing ratios of $\mathrm{RONO}_{2}$ (not shown). $\mathrm{RONO}_{2}$ chemistry is characterized by Reactions (49) to (51). In both $\mathrm{Br}_{2}-\mathrm{M} 4$ and $\mathrm{Br}_{2}-\mathrm{P} 4$ cases 15 the rates of the three reactions remained relatively small, but Reaction (51) prevailed. Only few pmol mol${ }^{-1}$ of $\mathrm{NO}_{2}$ molecules were produced in the model runs. The related chemistry remained similar to that of $\mathrm{NO}_{2}$. However, large variations of $\xi_{\mathrm{RONO}_{2}}$ did not substantially influence $\mathrm{O}_{3}$ : when multiplying $\xi_{\mathrm{RONO}}$ by a factor 10 compared to the base value (Table 3), ozone only increased by $3 \mathrm{nmol} \mathrm{mol}^{-1}$, in both $\mathrm{Br}_{2}-\mathrm{M} 4$ and $\mathrm{Br}_{2}-\mathrm{P} 4$ cases. Acid displacement of $\mathrm{HCl}$ by $\mathrm{HNO}_{3}$ also occurred under such chemistry.

Among $\mathrm{HONO}, \mathrm{NO}_{2}$ and $\mathrm{RONO}_{2}, \mathrm{HONO}$ was found the most important species affecting the bromine/ozone chemistry due to the production of both highly reactive $\mathrm{OH}$ and $\mathrm{NO}$. $\mathrm{NO}_{2}$ and $\mathrm{RONO}_{2}$ only showed a limited influence on bromine/ozone. We therefore encourage experimentalists to record HONO concentrations in particular, simultaneously with bromine/ozone. $\mathrm{RONO}_{2}$ only weakly affected ozone, but it is a relevant tracer providing information on the concentration of chlorine radicals (see Reaction 51).

\section{The chemistry} influencing ODEs

M. Piot and R. von

Glasow

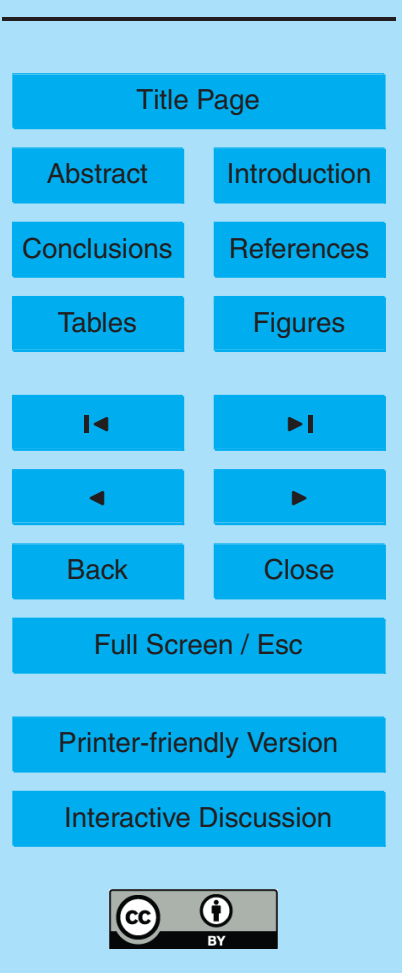




\section{Discussion of deposited bromine on snow}

In this paper, we did not consider the recycling of bromine from the snow, as we focused on boundary layer chemical reactions influencing bromine/ozone. However, recycling of deposited bromine on snow appears to be an important process for the re-emission 5 of reactive bromine (see Foster et al., 2001; Peterson and Honrath, 2001; Spicer et al., 2002). Moreover, Piot and von Glasow (2007) showed that the deposition/re-emission process is essential for the timing of an ODE.

The model results highlighted here apply only for constant fluxes of halogens. The different processes leading to the re-emission of deposited bromine on snow are not explicitly taken into account. Therefore, temporal/spatial variations of the flux of halogens in our model run are not investigated in this paper. The simulations where bromine deposition on snow represents an important loss pathway would have opposite effects compared to simulations including recycling on snow. In the sensitivity studies presented here, the deposition of bromine on snow only represents a loss of bromine for 15 the studied airmass. For results including recycling from the snow, the reader is referred to Piot and von Glasow (2007). It is important to stress that the chemistry in the PBL drastically changes, whether deposited bromine is recycled as reactive bromine or not.

\section{Conclusions}

20 The chemistry of $\mathrm{HCHO}, \mathrm{H}_{2} \mathrm{O}_{2}$, DMS, $\mathrm{Cl}_{2}, \mathrm{C}_{2} \mathrm{H}_{4}, \mathrm{C}_{2} \mathrm{H}_{6}, \mathrm{HONO}, \mathrm{NO}_{2}$, and $\mathrm{RONO}_{2}$ was investigated. Their impact on halogen/ozone in the PBL was assessed by the use of the box model MISTRA in the Lagrangian mode. We compared base runs undergoing $\mathrm{Br}_{2}-, \mathrm{Cl}_{2}^{-}$, or $\mathrm{BrCl}$-induced ODEs with similar runs including a modification in flux or mixing ratio of a species. Under conditions of elevated mixing ratios of $\mathrm{HCHO}, \mathrm{H}_{2} \mathrm{O}_{2}$, of $\mathrm{HO}_{\mathrm{x}}$ radicals. This shift in speciation increases the bromine explosion cycle in SSAs.
The chemistry influencing ODEs

M. Piot and R. von

Glasow

Title Page

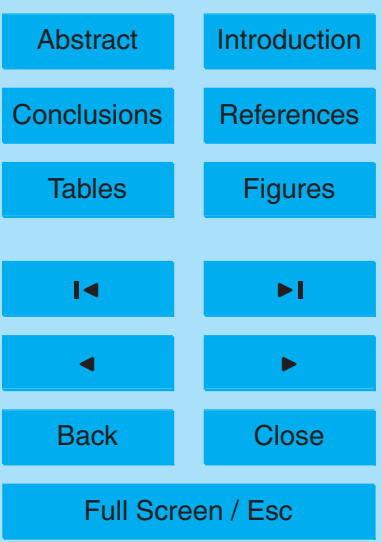

Printer-friendly Version

Interactive Discussion 
However, the main effect of this shift is rather the reduction in $\mathrm{BrO}$ self-reaction associated with the increased deposition on snow (mainly via $\mathrm{HOBr}$ deposition). In these cases, the total amount of gas phase bromine is reduced and the ozone depletion process slows down.

5 It was shown in this paper that ODEs caused by fluxes of $\mathrm{Cl}_{2}$ lead to unrealistic amounts of reactive chlorine compared to field measurements. Reactions involving reactive chlorine also release $\mathrm{CH}_{3} \mathrm{O}_{2}, \mathrm{HO}_{\mathrm{x}}$, and $\mathrm{ROOH}$ which react, again, with chlorine radicals to produce $\mathrm{HCl}$. We called this reaction chain "chlorine counter-cycle". Very large amounts of $\mathrm{HCl}$ are produced in order to deplete ozone. We noted that this 10 counter-cycle may be "activated" rapidly by the presence of sufficient concentrations of chlorine radicals (e.g., model run $\mathrm{Br}_{2}-\mathrm{M}_{4}-\mathrm{Cl}_{2}=5.0 \times 10^{8}$ molec $\mathrm{cm}^{-2} \mathrm{~s}^{-1}$ ). In that case, the activation of the chlorine counter-cycle unexpectedly leads to the reduction of reactive bromine and reduces the ozone depletion. Similar activations of this counter-cycle are also observed for the base run $\mathrm{BrCl}-\mathrm{M} 1$.

15 The chemistry of $\mathrm{C}_{2} \mathrm{H}_{6}$ mainly reduces the concentration of $\mathrm{HO}_{\mathrm{x}}$ in the air, which modifies the bromine speciation from $\mathrm{HOBr} / \mathrm{HBr}$ to $\mathrm{BrO} / \mathrm{Br} . \mathrm{C}_{2} \mathrm{H}_{6}$ cleanses the air from oxidants. However, the influence of high mixing ratios of $\mathrm{C}_{2} \mathrm{H}_{6}$ on ozone is found very weak. $\mathrm{C}_{2} \mathrm{H}_{6}$ has stronger effects on ODEs caused by $\mathrm{Cl}_{2}$ fluxes, as it converts chlorine radicals to $\mathrm{HCl}$ rather rapidly.

The chemistry of $\mathrm{C}_{2} \mathrm{H}_{4}$ clearly affects the concentrations of $\mathrm{HO}_{\mathrm{x}}$ and bromine radicals. Higher mixing ratios of $\mathrm{C}_{2} \mathrm{H}_{4}$ compared to base runs show a drastic reduction in bromine explosion efficiency. Less $\mathrm{HOBr}$ and more $\mathrm{HBr}$ clearly lead to the re-bromination of SSAs and the bromination of sulfate aerosols. The reduction of available gas phase bromine leads to less ozone depletion. Nevertheless, we also noted 25 that lower mixing ratios of $\mathrm{C}_{2} \mathrm{H}_{4}$ may also lead to less ozone depletion. Under such $\mathrm{C}_{2} \mathrm{H}_{4}$ conditions, longer $\mathrm{HO}_{\mathrm{x}}$ lifetimes lead to higher concentrations of $\mathrm{HOBr}$ than in the base run: the aerosol debromination is stronger. As mentioned for other species, the increase in $\mathrm{HOBr}$ leads to increased deposition on snow and a slow down in $\mathrm{BrO}$ self-reaction. Under low mixing ratios of $\mathrm{C}_{2} \mathrm{H}_{4}, \mathrm{Br}_{\mathrm{x}}$ also decreases compared to the

\section{The chemistry} influencing ODEs

M. Piot and R. von

Glasow

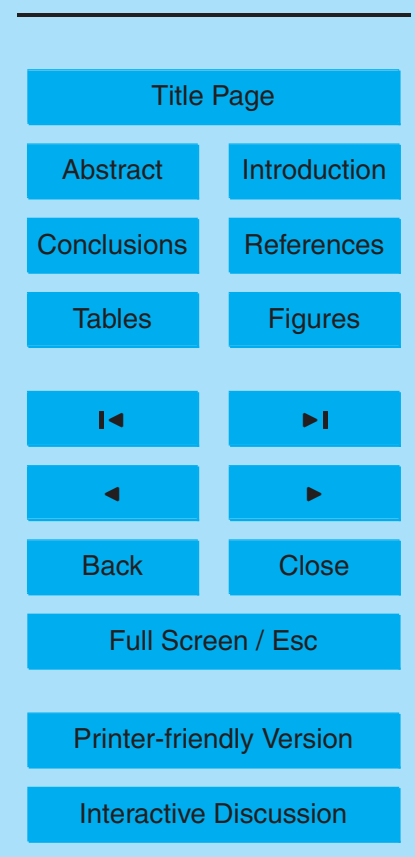


base run and the ozone depletion process slows down.

Among $\mathrm{HONO}, \mathrm{NO}_{2}$ and $\mathrm{RONO}_{2}$, $\mathrm{HONO}$ was found the most influencing nitrogencontaining species. The photolysis of $\mathrm{HONO}$ both releases highly reactive $\mathrm{OH}$ and NO. Both radicals induce a shift in bromine speciation to produce $\mathrm{HOBr} / \mathrm{HBr}$ and $5 \mathrm{BrONO}_{2} / \mathrm{BrNO}_{2}$. The main effect of this shift is the reduction in gas phase reactive bromine via deposition on snow. Ozone is less destroyed. For all three nitrogencontaining species, we noted an acid displacement in $\mathrm{SSAs}$ from $\mathrm{HNO}_{3}$ to $\mathrm{HCl}$ and the increased release of chlorine compared to bromine out of SSAs. We found more gas phase chlorine in model runs including high $\mathrm{NO}_{\mathrm{x}}$ than in base model runs.

10 Again, we want to stress that recycling of deposited halogen in/on snow is not included in this model. Therefore, variations in deposition on snow are not taken into account. Differences in model results may be important if this recycling on snow is included.

Acknowledgements. This work was funded by the Deutsche Forschungsgemeinschaft (DFG) 15 (Emmy Noether Junior Research group Marhal GL353/1,2). It is a contribution to the IGAC/SOLAS task "Halogens in the Troposphere" (HitT).

\section{References}

Adams, J. W., Holmes, N. S., and Crowley, J. N.: Uptake and Reaction of $\mathrm{HOBr}$ on Frozen and dry Salt Surfaces, Atmos. Chem. Phys., 2, 79-91, 2002,

20 http://www.atmos-chem-phys.net/2/79/2002/. 7408

AMAP report: Arctic Pollution Issues. Arctic Monitoring and Assessment Programme (AMAP), in: AMAP Assessment Report, pp. xii+859, AMAP, Oslo, Norway, 1998. 7402

Amoroso, A., Beine, H. J., Sparapani, R., Nardino, M., and Allegrini, I.: Observation of coinciding arctic boundary layer ozone depletion and snow surface emissions of nitrous acid,

25 Atmos. Environ., 1949-1956, doi:10.1016/j.atmosenv.2005.11.027, 2006. 7404

Andrews, J. E., Brimblecombe, P., Jickells, T. D., and Liss, P. S.: An Introduction to Environmental Chemistry, Blackwell Science, 2004. 7437

\section{The chemistry} influencing ODEs

M. Piot and R. von

Glasow

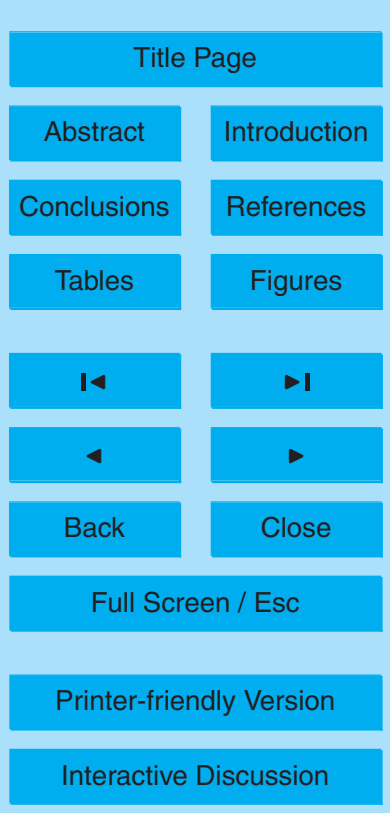


Anlauf, K. G., Mickle, R. E., and Trivett, N. B. A.: Measurement of ozone during Polar Sunrise Experiment 1992, J. Geophys. Res., 99, D12, 25 345-25354, doi:10.1029/94JD01312, 1994. 7438

Aranda, A., Le Bras, G., La Verdet, G., and Poulet, G.: The BrO $+\mathrm{CH}_{3} \mathrm{O}_{2}$ reaction: Kinetics and role in the atmospheric ozone budget, Geophys. Res. Lett., 24, 22, 2745-2748, doi:10.1029/97GL02686, 1997. 7395

Ariya, P. A., Jobson, B. T., Sander, R., Niki, H., Harris, G. W., Hopper, J. F., and Anlauf, K. G.: Measurements of $C_{2}-C_{7}$ hydrocarbons during the Polar Sunrise Experiment 1994: Further evidence for halogen chemistry in the troposphere, J. Geophys. Res., 103, D11, 13169 $10 \quad 13$ 180, doi:10.1029/98JD00284, 1998. 7401

Ariya, P. A., Hopper, J. F., and Harris, G. W.: $\mathrm{C}_{2}-\mathrm{C}_{7}$ hydrocarbon concentrations in Arctic snowpack interstitial air: Potential presence of active $\mathrm{Br}$ within the snowpack, J. Atmos. Chem., 34, 1, 55-64, doi:10.1023/A:1006289618755, 1999. 7401, 7402, 7415, 7417

Bales, R. C., McConnell, J. R., Losleben, M. V., Conklin, M. H., Fuhrer, K., Neftel, A., Dibb, 15 J. E., Kahl, J. D. W., and Stearns, C. R.: Diel Variations of $\mathrm{H}_{2} \mathrm{O}_{2}$ in Greenland: A Discussion of the Cause and Effect Relationship, J. Geophys. Res., 100, D9, 18661-18668, doi:10.1029/95JD01841, 1995. 7410

Barnes, I., Bastian, V., Becker, K. H., and Overrath, R. D.: Kinetic studies of the reactions of IO, $\mathrm{BrO}$ and $\mathrm{ClO}$ with DMS, Int. J. Chem. Kinet., 23, 579-591, 1991. 7400

20 Barrie, L. A. and Hoff, R. M.: The oxidation rate and residence time of sulphur dioxide in the arctic atmosphere, Atmos. Environ., 18, 12, 2711-2722, 1984. 7438

Barrie, L. A., Bottenheim, J. W., Schnell, R. C., Crutzen, P. J., and Rasmussen, R. A.: Ozone destruction and photochemical reactions at polar sunrise in the lower Arctic atmosphere, Nature, 334, 138-141, doi:10.1038/334138a0, 1988. 7393

Barrie, L. A., den Hartog, G., Bottenheim, J. W., and Landsberger, S.: Anthropogenic aerosols and gases in the lower troposphere at Alert, Canada in April 1986, J. Atmos. Chem., 9, 1-3, 101-127, doi:10.1007/BF00052827, 1989. 7393

Barrie, L. A., Bottenheim, J. W., and Hart, W. R.: Polar Sunrise Experiment 1992 (PSE 1992): Preface, J. Geophys. Res., 99, D12, 25313-25314, doi:10.1029/94JD01929, 1994. 7399, 7438

Behnke, W., George, C., Scheer, V., and Zetzsch, C.: Production and decay of $\mathrm{CINO}_{2}$ from the reaction of gaseous $\mathrm{N}_{2} \mathrm{O}_{5}$ with $\mathrm{NaCl}$ solution: Bulk and aerosol experiments, J. Geophys. Res., 102, D3, 3795-3804, doi:10.1029/96JD03057, 1997. 7404

\section{The chemistry influencing ODEs}

M. Piot and R. von

Glasow

Title Page

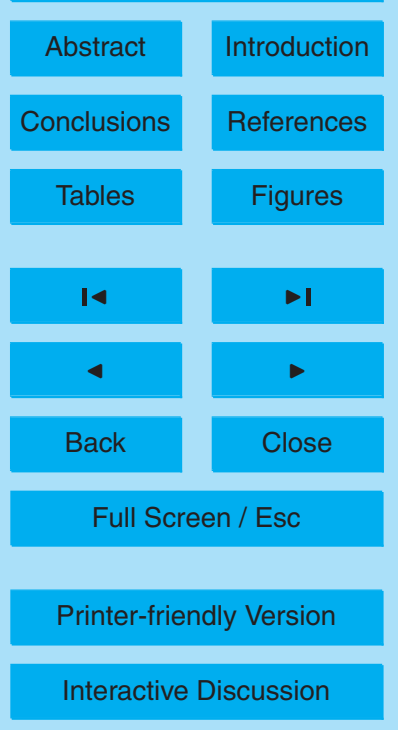


Beine, H. J., Honrath, R. E., Dominé, F., Simpson, W. R., and Fuentes, J. D.: NO ${ }_{x}$ during background and ozone depletion periods at Alert: Fluxes above the snow surface, J. Geophys. Res., 107, D21, 4584, doi:10.1029/2002JD002082, 2002. 7403

Beine, H. J., Dominé, F., Ianniello, A., Nardino, M., Allegrini, I., Teinila, K., and Hillamo, R.: Fluxes of nitrates between snow surfaces and the atmosphere in the European high Arctic, Atmos. Chem. Phys., 3, 335-346, 2003, http://www.atmos-chem-phys.net/3/335/2003/. 7404

Beine, J., Jaffe, D. A., Stordal, F., Engardt, M., Solberg, S., Schmidbauer, N., and Holmen, K.: $\mathrm{NO}_{\mathrm{x}}$ during ozone depletion events in the arctic troposphere at Ny-Ålesund, Svalbard, Tellus, 49B, 5, 556-565, 1997. 7438

10 Bloss, W. J., Lee, J. D., Heard, D. E., Salmon, R. A., Bauguitte, S. J.-B., Roscoe, H. K., and Jones, A. E.: Observations of $\mathrm{OH}$ and $\mathrm{HO}_{2}$ radicals in coastal Antarctica, Atmos. Chem. Phys., 7, 4171-4185, 2007, http://www.atmos-chem-phys.net/7/4171/2007/. 7407

Bottenheim, J. W., Gallant, A. J., and Brice, K. A.: Measurements of $\mathrm{NO}_{\mathrm{y}}$ species and $\mathrm{O}_{3}$ at $82^{\circ} \mathrm{N}$ latitude, Geophys. Res. Lett., 13, 2, 113-116, 1986. 7393, 7438

Bottenheim, J. W., Barrie, L. A., Atlas, E., Heidt, L. E., Niki, H., Rasmussen, R. A., and Shepson, P. B.: Depletion of lower tropospheric ozone during Arctic spring: The polar sunrise experiment 1988, J. Geophys. Res., 95, 18555-18568, 1990. 7393, 7438

Bottenheim, J. W., Boudries, H., Brickell, P., and Atlas, E.: Alkenes in the Arctic Boundary Layer at Alert, Nunavut, Canada, Atmos. Environ., 36, 15, 2585-2594, doi:10.1016/S13522310(02)00113-9, 2002a. 7402, 7406

Bottenheim, J. W., Dibb, J. E., Honrath, R. E., and Shepson, P. B.: An introduction to the Alert 2000 and Summit 2000 Arctic research studies, Atmos. Environ., 36, 15, 2467-2469, doi:10.1016/S1352-2310(02)00135-8, 2002b. 7438

Boudries, H. and Bottenheim, J. W.: Cl and Br Atom Concentrations During a Surface Boundary 25 Layer Ozone Depletion Event in the Canadian High Arctic, Geophys. Res. Lett., 27, 4, 517520, 2000. 7413, 7414, 7415

Brasseur, G. P., Orlando, J. J., and Tyndall, G. S.: Atmospheric Chemistry and Global Change, Oxford University Press, New York, Oxford, 1999. 7404

Carter, W. P. L. and Atkinson, R.: Atmospheric chemistry of alkanes, J. Atmos. Chem., 3, 3, 377-405, doi:10.1007/BF00122525, 1985. 7404

Charlson, R. J., Lovelock, J. E., Andreae, M. O., and Warren, S. G.: Oceanic phytoplankton, atmospheric sulphur, cloud albedo and climate, Nature, 326, 655-661, doi:10.1038/326655a0, 1987. 7400

\section{The chemistry influencing ODEs}

M. Piot and R. von Glasow

Title Page

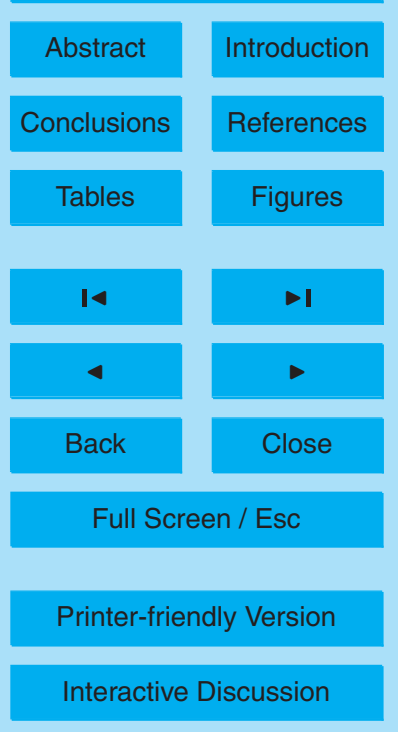


Conklin, M. H., Sigg, A., Neftel, A., and Bales, R. C.: Atmosphere-Snow Transfer Function for $\mathrm{H}_{2} \mathrm{O}_{2}$ Microphysical Considerations, J. Geophys. Res., 98, D10, 18367-18376, 1993. 7400

Damian, V., Sandu, A., Damian, M., Potra, F., and Carmichael, G. R.: The kinetic preprocessor KPP-a software environment for solving chemical kinetics, Comp. Chem. Eng., 26, 15675 1579, 2002. 7398

de Serves, C.: Gas phase formaldehyde and peroxide measurements in the Arctic atmosphere, J. Geophys. Res., 99, D12, 25 391-25 398, doi:10.1029/94JD00547, 1994. 7408, 7410, 7438

Dominé, F., Taillandier, A. S., Simpson, W. R., and Severin, K.: Specific surface area, density and microstructure of frost flowers, Geophys. Res. Lett., 32, L13502, doi:10.1029/2005GL023245, 2005. 7396

Doskey, P. V. and Gaffney, J. S.: Non-methane hydrocarbons in the Arctic atmosphere at Barrow, Alaska, Geophys. Res. Lett., 19, 4, 381-384, 1992. 7415

Eigen, M. and Kustin, K.: The kinetics of halogen hydrolysis, J. Am. Chem. Soc., 84, 13551361, 1962. 7395

Evans, M. J., Jacob, D. J., Atlas, E., Cantrell, C. A., Eisele, F., Flocke, F., Fried, A., Mauldin, R. L., Ridley, B. A., Wert, B., Walega, J., Weinheimer, A., Blake, D., Heikes, B., Snow, J., Talbot, R., and Dibb, J.: Coupled evolution of $\mathrm{BrO}_{\mathrm{x}}-\mathrm{ClO}_{\mathrm{x}}-\mathrm{HO}_{\mathrm{x}}-\mathrm{NO}_{\mathrm{x}}$, chemistry during bromine-catalyzed ozone depletion events in the arctic boundary layer, J. Geophys. Res., 108, D4, doi:10.1029/2002JD002732, 2003. 7396, 7402

20 Fan, S.-M. and Jacob, D. J.: Surface ozone depletion in Arctic spring sustained by bromine reactions on aerosols, Nature, 359, 522-524, doi:10.1038/359522a0, 1992. 7395, 7396, 7415

Ferek, R. J., Hobbs, P. V., Radke, L. F., and Herring, J. A.: Dimethyl sulfide in the arctic atmosphere, J. Geophys. Res., 100, D12, 26 093-26 104, 1995. 7436

Fickert, S., Adams, J. W., and Crowley, J. N.: Activation of $\mathrm{Br}_{2}$ and $\mathrm{BrCl}$ via uptake of $\mathrm{HOBr}$ onto aqueous salt solutions, J. Geophys. Res., 104, D19, 23719-23727, doi:10.1029/1999JD900359, 1999. 7395, 7408

Finlayson-Pitts, B. J. and Pitts, Jr., J. N.: Chemistry of the Upper and Lower Atmosphere, Academic Press Inc., 1999. 7399

30 Foster, K. L., Plastridge, R. A., Bottenheim, J. W., Shepson, P. B., Finlayson-Pitts, B. J., and Spicer, C. W.: The Role of $\mathrm{Br}_{2}$ and $\mathrm{BrCl}$ in Surface Ozone Destruction at Polar Sunrise, Science, 291, 471-474, doi:10.1126/science.291.5503.471, 2001. 7393, 7401, 7406, 7414, 7415,7422

\section{The chemistry influencing ODEs}

M. Piot and R. von

Glasow

Title Page

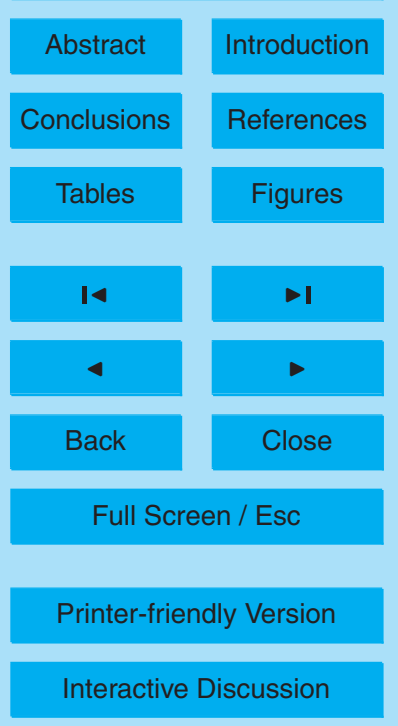


Frey, M. M., Hutterli, M. A., Chen, G., Friel, D. K., and Bales, R. C.: Boundary Layer Chemistry of Hydroperoxides $\left(\mathrm{H}_{2} \mathrm{O}_{2}\right.$ and $\mathrm{CH}_{3} \mathrm{OOH}$ in Greenland (Sumit) and Antarctica (South Pole): Links to Atmospheric Oxidation Capacity), Geoph. Res. Abstr., 8, 05261, 16077962/gra/EGU06-A-05261, 2006. 7401

5 Fuhrer, K., Hutterli, M., and McConnell, J. R.: Overview of recent field experiments for the study of the air-snow transfer of $\mathrm{H}_{2} \mathrm{O}_{2}$ and $\mathrm{HCHO}$, in: Chemical Exchange Between the Atmosphere and Polar Snow, edited by Springer-Verlag, N. Y., NATO ASI Series, 43, 1996. 7400

Hara, K., Osada, K., Matsunaga, K., Iwasaka, Y., Shibata, T., and Furuya, K.: Atmospheric inorganic chlorine and bromine species in Arctic boundary layer of the winter/spring, J. Geophys. Res., 107 (D18), doi:10.1029/2001JD001 008, 4361, 2002. 7420

Hausmann, M. and Platt, U.: Spectroscopic measurement of bromine oxide and ozone in the high Arctic during Polar Sunrise Experiment 1992, J. Geophys. Res., 99, D12, 25399 25 413, 10.1029/94JD01314, 1994. 7393

Heikes, B. G. and Thompson, A. M.: Effects of Heterogeneous Processes on $\mathrm{NO}_{3}, \mathrm{HONO}$ and $\mathrm{HNO}_{3}$ Chemistry in the Troposphere, J. Geophys. Res., 88, C15, 10 883-10 895, 1983. 7404

Honrath, R. E., Peterson, M. C., Guo, S., Dibb, J. E., Shepson, P. B., and Campbell, B.: Evidence of $\mathrm{NO}_{\mathrm{x}}$ Production Within or Upon Ice Particles in the Greenland Snowpack, Geophys. Res. Lett., 26, 6, 695-698, doi:10.1029/2000JD900361, 1999. 7403

20 Honrath, R. E., Guo, S., Peterson, M. C., Dziobak, M. P., Dibb, J. E., and Arsenault, M. A.: Photochemical production of gas phase $\mathrm{NO}_{x}$ from ice crystal $\mathrm{NO}_{3}^{-}$, J. Geophys. Res., 105, D19, 24 183-24 190, doi:10.1029/1999GL011286, 2000a. 7403

Honrath, R. E., Peterson, M. C., Dziobak, M. P., Dibb, J. E., Arsenault, M. A., and Green, S. A.: Release of $\mathrm{NO}_{x}$ from Sunlight-irradiated Midlatitude Snow, Geophys. Res. Lett., 27, 15, 2237-2240, doi:10.1029/1999GL011286, 2000b. 7403

Hopper, J. F. and Hart, W.: Meteorological aspects of the 1992 Polar Sunrise Experiment, J. Geophys. Res., 99, D12, 25315-25 328, doi:10.1029/94JD02400, 1994. 7397

Hopper, J. F., Peters, B., Yokouchi, Y., Niki, H., Jobson, B. T., Shepson, P. B., and Muthuramu, K.: Chemical and meteorological observations at ice camp SWAN during Polar Sunrise Experiment 1992, J. Geophys. Res., 99, D12, 25 489-25 498, doi:10.1029/94JD02303, 1994. 7398,7438

Hopper, J. F., Barrie, L. A., Silis, A., Hart, W., Gallant, A. J., and Dryfhout, H.: Ozone and meteorology during the 1994 Polar Sunrise Experiment, J. Geophys. Res., 103, D1, 1481-

\section{The chemistry influencing ODEs}

M. Piot and R. von Glasow

Title Page

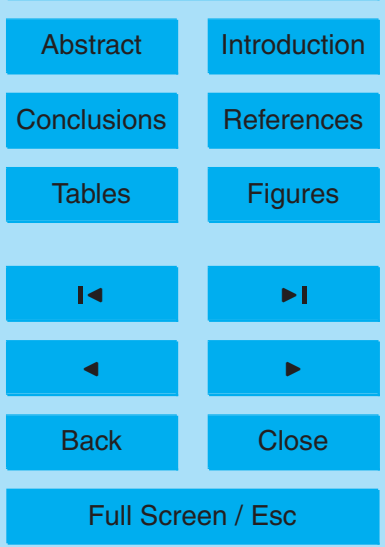

Printer-friendly Version

Interactive Discussion 
1492, doi:10.1029/97JD02888, 1998. 7397

Hutterli, M. A., Connell, J. R. M., Stewart, R. W., Jacobi, H.-W., and Bales, R. C.: Impact of temperature-driven cycling of hydrogen peroxide $\left(\mathrm{H}_{2} \mathrm{O}_{2}\right)$ between air and snow on the planetary boundary layer, J. Geophys. Res., 106, D14, 15393-15404, 5 doi:10.1029/2001JD900102, 2001. 7400, 7406, 7410, 7411

Hutterli, M. A., Bales, R. C., McConnell, J. R., and Stewart, R. W.: HCHO in Antarctic snow: Preservation in ice cores and air-snow exchange, Geophys. Res. Lett., 29, 8 , doi:10.1029/2001GL014256, 2002. 7399

Hutterli, M. A., Connell, J. R. M., Chen, G., Bales, R. C., Davis, D. D., and Lenschow, D. H.: Formaldehyde and hydrogen peroxide in air, snow and interstitial air at South Pole, Atmos. Environ., 38, 32, 5439-5450, doi:10.1016/j.atmosenv.2004.06.003, 2004. 7400, 7410

Impey, G. A., Shepson, P. B., Hastie, D. R., Barrie, L. A., and Anlauf, K. G.: Measurements of photolyzable chlorine and bromine during the Polar Sunrise Experiment 1995, J. Geophys. Res., 102, D13, 16 005-16 010, doi:10.1029/97JD00851, 1997. 7413

Jacob, D. J.: Heterogeneous chemistry and tropospheric ozone, Atmos. Environ., 34 (12-14), 2131-2190, doi:10.1016/S1352-2310(99)00462-8, 2000. 7401

Jacobi, H.-W., Frey, M. M., Hutterli, M. A., Bales, R. C., Schrems, O., Cullen, N. J., Steffen, K., and Koehler, C.: Measurements of hydrogen peroxide and formaldehyde exchange between the atmosphere and surface snow at Summit, Greenland, Atmos. Environ., 36, 2619-2628, doi:10.1016/S1352-2310(02)00106-1, 2002. 7399, 7400, 7409, 7410

Jacobi, H.-W., Bales, R. C., Honrath, R. E., Peterson, M. C., Dibb, J. E., Swanson, A. L., and Albert, M. R.: Reactive trace gases measured in the interstitial air of surface snow at Summit, Greenland, Atmos. Environ., 38, 1687-1697, doi:10.1016/j.atmosenv.2004.01.004, 2004. 7399, 7403

Jaenicke, R.: Aerosol Physics and Chemistry, in: Landolt-Börnstein "Zahlenwerte und Funktionen aus Naturwissenschaften und Technik", V 4b, 391-457, Springer, 1988. 7437

Jobson, B. T., Niki, H., Yokouchi, Y., Bottenheim, J., Hopper, F., and Leaitch, R.: Measurements of $\mathrm{C}_{2}-\mathrm{C}_{6}$ hydrocarbons during the Polar Sunrise 1992 Experiment: Evidence for $\mathrm{Cl}$ atom and $\mathrm{Br}$ atom chemistry, J. Geophys. Res., 99, D12, 25 355-25 368, doi:10.1029/94JD01243, 1994. 7398, 7401, 7402, 7414, 7415, 7438

Kaleschke, L., Richter, A., Burrows, J., Afe, O., Heygster, G., Notholt, J., Rankin, A. M., Roscoe, H. K., Hollwedel, J., Wagner, T., and Jacobi, H.-W.: Frost flowers on sea ice as a source of sea salt and their influence on tropospheric halogen chemistry, Geophys. Res. Lett., 31,

\section{The chemistry influencing ODEs}

M. Piot and R. von Glasow

Title Page

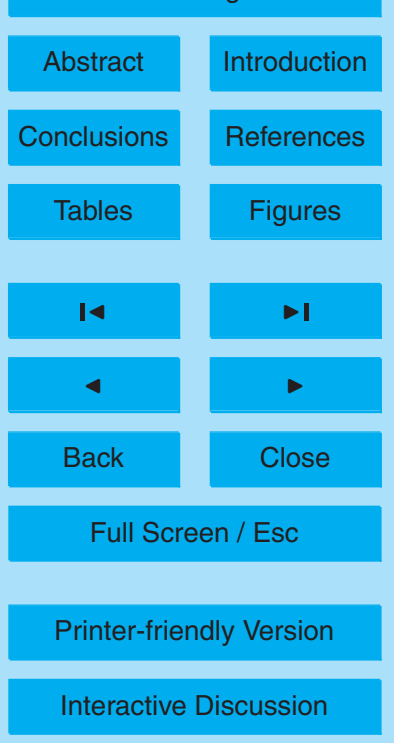


L16114, doi:10.1029/2004GL020655, 2004. 7396

Keene, W. C., Aslam, M., Khalil, K., Erickson, D. J., McCulloch, A., Graedel, T. E., Lobert, J. M., Aucott, M. L., Gong, S. L., Harper, D. B., Kleiman, G., Midgley, P., Moore, R. M., Seuzaret, C., Sturges, W. T., Benkovitz, C. M., Koropalov, V., Barrie, L. A., and Li, Y. F.: Composite global 5 emissions of reactive chlorine from anthropogenic and natural sources: Reactive Chlorine Emissions Inventory, J. Geophys. Res., 104, D7, 8429-8440, doi:10.1029/1998JD100084, 1999. 7401

Keil, A. D. and Shepson, P. B.: Chlorine and bromine atom ratios in the springtime Arctic troposphere as determined from measurements of halogenated volatile organic compounds,

$10 \quad$ J. Geophys. Res., 111, D17303, doi:10.1029/2006JD007119, 2006. 7402

Koop, T., Kapilashrami, A., Molina, L. T., and Molina, M. J.: Phase transitions of sea-salt/water mixtures at low temperatures: Implications for ozone chemistry in the polar marine boundary layer, J. Geophys. Res., 105, D21, 26 393-26 402, doi:2000JD900413, 2000. 7397

Landgraf, J. and Crutzen, P.: An Efficient Method for 'On-Line' Calculations of Photolysis and

15 Heating Rates, J. Atmos. Sci., 55, 863-878, 1998. 7398

Leaitch, W. R., Barrie, L. A., Bottenheim, J. W., and Li, S. M.: Airborne observations related to ozone depletion at polar sunrise, J. Geophys. Res., 99 (D12), 25 499-25517, doi:10.1029/94JD02750, 1994. 7438

Lehrer, E., Wagenbach, D., and Platt, U.: Aerosol chemical composition during tropospheric 20 ozone depletion at Ny-Ålesund/Svalbard, Tellus, 49B, 5, 486-495, doi:10.1034/j.16000889.49, 1997. 7393

Lehrer, E., Hönninger, G., and Platt, U.: A one dimensional model study of the mechanism of halogen liberation and vertical transport in the polar troposphere, Atmos. Chem. Phys., 4, 2427-2440, 2004, http://www.atmos-chem-phys.net/4/2427/2004/. 7396, 7415

$\mathrm{Li}, \mathrm{S} .-\mathrm{M} .:$ Equilibrium of particle nitrite with gas phase HONO: Tropospheric measurements in the high Arctic during polar sunrise, J. Geophys. Res., 99, D12, 25 469-25 478, 1994. 7438

Martin, S., Drucker, R., and Fort, M.: A laboratory study of frost flower growth on the surface of young sea-ice, J. Geophys. Res., 100, C4, 7027-7036, doi:10.1029/94JC03243, 1995. 7396

McConnell, J. C., Henderson, G. S., Barrie, L., Bottenheim, J., Niki, H., Langford, C. H., and

30 Templeton, E. M. J.: Photochemical bromine production implicated in Arctic boundary-layer ozone depletion, Nature, 355, 150-152, 1992. 7395, 7396

Michalowski, B. A., Francisco, J. S., Li, S.-M., Barrie, L. A., Bottenheim, J. W., and Shepson, P. B.: A computer model study of multiphase chemistry in the Arctic boundary layer dur-

\section{The chemistry influencing ODEs}

M. Piot and R. von

Glasow

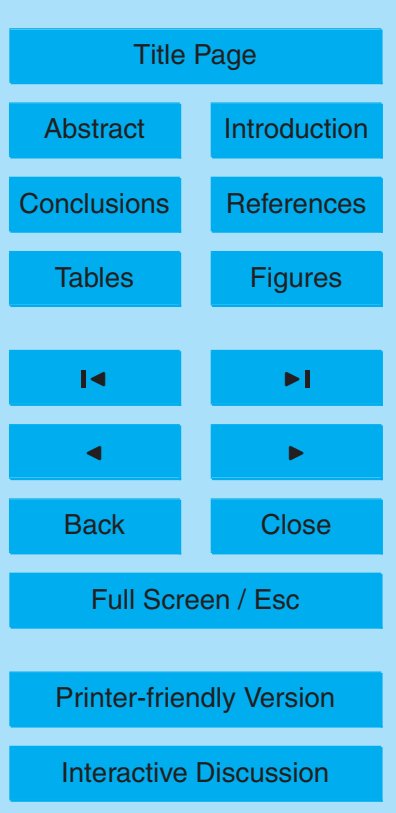


ing polar sunrise, J. Geophys. Res., 105, D12, 15 131-15 145, doi:10.1029/2000JD900004, 2000. 7396,7408

Monahan, E. C., Spiel, D. E., and Davidson, K. L.: A model of marine aerosol generation via whitecaps and wave disruption, in: Oceanic Whitecaps, edited by: Monahan, E. C. and

$5 \quad$ Niocaill, G. M., 167-174, D. Reidel, Norwell, Mass, 1986. 7397

Mozurkewich, M.: Mechanisms for the release of halogens from sea-salt particles by free radical reactions, J. Geophys. Res., 100, D7, 14 199-14207, doi:10.1029/94JD00358, 1995. 7395

Neftel, A., Bales, R. C., and Jacob, D. J.: $\mathrm{H}_{2} \mathrm{O}_{2}$ and $\mathrm{HCHO}$ in Polar Snow and Their Relation to Atmospheric Chemistry, in: Ice Core Studies of Global Biogeochemical Cycles, edited by: R. Delmas, NATO ASI Ser., S. I., 30, 249-264, 1995. 7400

Oltmans, S. J. and Komhyr, W.: Surface ozone distributions and variations from 1973 - 1984 measurements at the NOAA Geophysical Monitoring for Climate Change Baseline observatories, J. Geophys. Res., 91, D4, 5229-5236, 1986. 7393

Perner, D. and Platt, U.: Detection of Nitrous Acid in the Atmosphere by Differential Optical Absorption, Geophys. Res. Lett., 6, 12, 917-920, 1979. 7404

Perner, D., Arnold, T., Crowley, J., Klüpfel, T., Martinez, M., and Seuwen, R.: The measurements of active chlorine in the atmosphere by chemical amplification, J. Atmos. Chem., 34, 1, 9-20, doi:10.1023/A:1006208828324, 1999. 7393, 7401, 7413, 7414

Peterson, M. C. and Honrath, R. E.: Observations of Rapid Photochemical Destruction of Ozone in Snowpack Interstitial Air, Geophys. Res. Lett., 28, 3, 511-514, doi:10.1029/2000GL012129, 2001. 7422

Piot, M. and von Glasow, R.: The Potential Importance of Frost Flowers, Recycling on Snow, and Open Leads for Ozone Depletion Events, Atmos. Chem. Phys. Discuss., 7, 4521-4595, 2007, http://www.atmos-chem-phys-discuss.net/7/4521/2007/. 7396, 7397, 7405, 7409, 7411,7422

Platt, U. and Lehrer, E.: Arctic Tropospheric Ozone Chemistry, Tech. Rep. NO. EV5V-CT930318, ARCTOC, Final Report of the EU-Project, Heidelberg, 1996. 7395

Pruppacher, H. R. and Klett, J. D.: Microphysics of Clouds and Precipitation, Kluwer Academic Pub., Dordrecht/Boston/London, 1997. 7397

Quinn, P. K., Bates, T. S., johnson, J. E., Covert, D. S., and Charlson, R. J.: Interactions Between the Sulfur and Reduced Nitrogen Cycles Over the Central Pacific Ocean, J. Geophys. Res., 95, 16 405-16 416, 1990. 7436

\section{The chemistry influencing ODEs}

M. Piot and R. von

Glasow

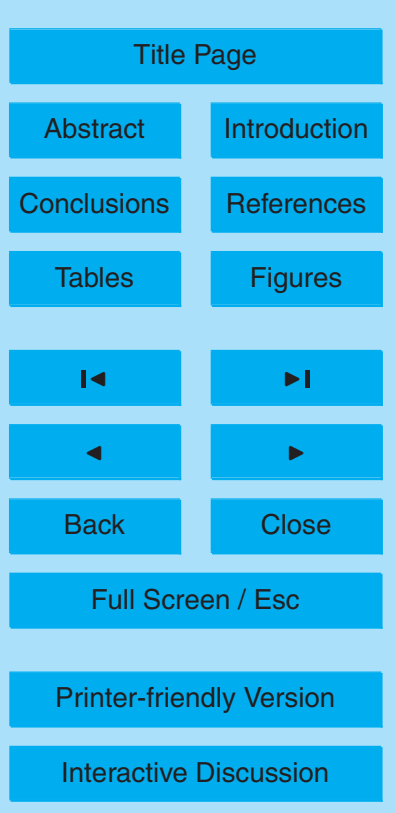


Ramacher, B., Rudolph, J., and Koppmann, R.: Hydrocarbon measurements during tropospheric ozone depletion events: Evidence for halogen atom chemistry, J. Geophys. Res., 104, C3, 3633-3653, doi:10.1029/2000GL011771, 1999. 7401, 7438

Rankin, A. M., Auld, V., and Wolff, E. W.: Frost flowers as a source of fractionated sea salt aerosol in the polar regions, Geophys. Res. Lett., 27, 21, 3469-3472, doi:10.1029/2000GL011771, 2000. 7396

Richardson, C. and Keller, E. E.: The brine content of sea ice measured with a nuclear magnetic resonance spectrometer, J. Glaciol., 6, 89-100, 1966. 7396

Richter, A., Wittrock, F., Eisinger, M., and Burrows, J. P.: GOME Observations of Tropospheric $\mathrm{BrO}$ in Northern Hemispheric Spring and Summer 1997, Geophys. Res. Lett., 25, 14, $2683-$ 2686, doi:10.1029/98GL52016, 1998. 7393

Ridley, B. A., Atlas, E. L., Montzka, D. D., Browell, E. V., Cantrell, C. A., Blake, D. R., Blake, N. J., Cinquini, L., Coffey, M. T., Emmons, L. K., Cohen, R. C., DeYoung, R. J., Dibb, J. E., Eisele, F. L., Flocke, F. M., Fried, A., Grahek, F. E., Grant, W. B., Hair, J. W., Hannigan, J., Heikes, B. J., Lefer, B. L., Mauldin, R. L., Moody, J. L., Shetter, R. E., Snow, J. A., Talbot, R. W., Thornton, J. A., Walega, J. G., Weinheimer, A. J., Wert, B. P., and Wimmers, A. J.: Ozone Depletion Events Observed in the High Latitude Surface Layer During the TOPSE Aircraft Program, J. Geophys. Res., 108, D4, doi:10.1029/2001JD001507, 2003. 7393, 7397, 7398, 7399, 7405, 7438

20 Robbins, R. C., Cadle, R. D., and Eckhardt, D. L.: The conversion of sodium chloride to hydrogen chloride in the atmosphere, J. Meteor., 16, 53-56, 1959. 7420

Sander, R., Vogt, R., Harris, G. W., and Crutzen, P. J.: Modeling the chemistry of ozone, halogen compounds, and hydrocarbons in the arctic troposphere during spring, Tellus, 49B, 5, 522-532, 1997. 7396, 7415, 7438

Sander, R., Rudich, Y., von Glasow, R., and Crutzen, P. J.: The role of $\mathrm{BrNO}_{3}$ in marine tropospheric chemistry: A model study, Geophys. Res. Lett., 26, 18, 2857-2860, doi:10.1029/1999GL900478, 1999. 7404

Sandu, A., Verwer, J. G., Blom, J. G., Spee, E. J., and Carmichael, G. R.: Benchmarking stiff ODE solvers for atmospheric chemistry problems II: Rosenbrock solvers, Tech. Rep. NM-R9614, Centrum voor Wiskunde en Informatica, Amsterdam, The Netherlands, http: //www.cwi.nl, 1996. 7397

Schwartz, S. E.: Mass-Transport Considerations Pertinent to Aqueous Phase Reactions of Gases in Liquid-Water Clouds, in: Chemistry of Multiphase Atmospheric Systems, edited by:

\section{The chemistry influencing ODEs}

M. Piot and R. von

Glasow

Title Page

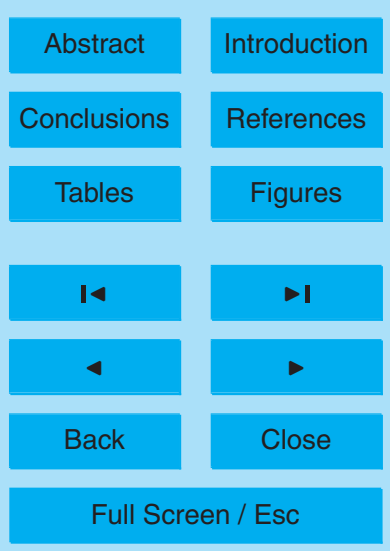

Printer-friendly Version

Interactive Discussion 
Jaeschke, W., pp. 415-471, NATO ASI Series, G6, 1986. 7397

Seinfeld, J. H. and Pandis, S. N.: Atmospheric Chemistry and Physics, John Wiley \& Sons, New York, Chichester, Weinheim, 1998. 7399

Simpson, W. R., Carlson, D., Hönninger, G., Douglas, T. A., Sturm, M., Perovich, D., and Platt, $5 \quad$ U.: First-year sea-ice contact predicts bromine monoxide $(\mathrm{BrO})$ levels at Barrow, Alaska better than potential frost flower contact, Atmos. Chem. Phys., 7, 621-627, 2007a. 7396

Simpson, W. R., von Glasow, R., Riedel, K., Anderson, P., Ariya, P., Bottenheim, J., Burrows, J., Carpenter, L., Frie, U., Goodsite, M. E., Heard, D., Hutterli, M., Jacobi, H.-W., Kaleschke, L., Neff, B., Plane, J., Platt, U., Richter, A., Roscoe, H., Sander, R., Shepson, P., Sodeau, J., Steffen, A., Wagner, T., and Wolff, E.: Halogens and their role in polar boundary-layer ozone depletion, Atmos. Chem. Phys., 7, 4375-4418, 2007b. 7393, 7394, 7399

Snow, J. A., Heikes, B. G., Merrill, J. T., Wimmers, A. J., Moody, J. L., and Cantrell, C. A.: Winter-spring evolution and variability of $\mathrm{HO}_{x}$ reservoir species, hydrogen peroxide and methyl hydroperoxide, in the northern mid to high-latitudes, J. Geophys. Res., 108, D4, doi:10.1029/2002JD002172, 2002. 7438

Spicer, C. W., Plastridge, R. A., Foster, K. L., Finlayson-Pitts, B. J., Bottenheim, J. W., Grannas, A. M., and Shepson, P. B.: Molecular halogens before and during ozone depletion events in the Arctic at polar sunrise: concentrations and sources, Atmos. Environ., 36, 15-16, 27212731, doi:10.1016/S1352-2310(02)00125-5, 2002. 7393, 7401, 7422

20 Stroud, C., Madronich, S., Atlas, E., Ridley, B., Flocke, F., Weinheimer, A., Talbot, B., Fried, A., Wert, B., Shetter, R., Lefer, B., Coffey, M., Heikes, B., and Blake, D.: Photochemistry in the arctic free troposphere: $\mathrm{NO}_{x}$ budget and the role of odd nitrogen reservoir recycling, Atmos. Environ., 37, 24, 3351-3364, doi:10.1016/S1352-2310(03)00353-4, 2003. 7438

Sumner, A. L. and Shepson, P. B.: Snowpack production of formaldehyde and its effect on the Arctic troposphere, Nature, 398, 6724, 230-233, doi:10.1038/18423, 1999. 7399, 7406, 7408,7438

Sumner, A. L., Shepson, P. B., Grannas, A. M., Bottenheim, J. W., Anlauf, K. G., Worthy, D., Schroeder, W. H., Steffen, A., Dominé, F., Perrier, S., and Houdier, S.: Atmospheric chemistry of formaldehyde in the Arctic troposphere at Polar Sunrise, and the influence of the snowpack, Atmos. Environ., 36, 15-16, 2553-2562, 2002. 7408

Swanson, A. L., Blake, N. J., Dibb, J. E., Albert, M. R., Blake, D. R., and Rowland, F. S.: Photochemically induced production of $\mathrm{CH}_{3} \mathrm{Br}, \mathrm{CH}_{3} \mathrm{l}, \mathrm{C}_{2} \mathrm{H}_{5} \mathrm{l}$, ethene, and propene within surface snow at Summit, Greenland, Atmos. Environ., 36, 15, 2671-2682, doi:10.1016/S1352-

\section{The chemistry influencing ODEs}

M. Piot and R. von

Glasow

Title Page

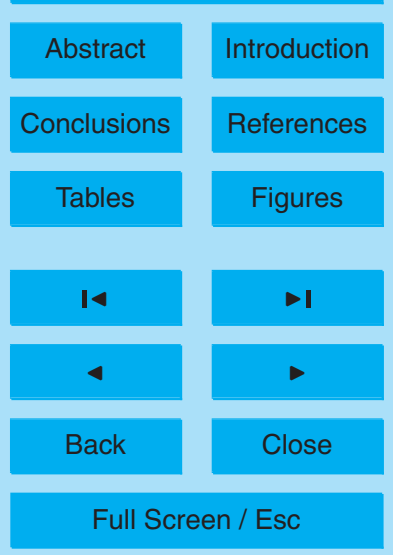

Printer-friendly Version

Interactive Discussion 
2310(02)00127-9, 2002. 7417

Tang, T. and McConnell, J. C.: Autocatalytic release of bromine from Arctic snow pack during polar sunrise, Geophys. Res. Lett., 23, 19, 2633-2636, doi:10.1029/96GL02572, 1996. 7395, 7396

5 Toumi, R.: BrO as a sink for dimethylsulphide in the marine atmosphere, Geophys. Res. Lett., 21, 2, 117-120, 1994. 7400

Tuckermann, M., Ackermann, R., Gölz, C., Lorenzen-Schmidt, H., Senne, T., Stutz, J., Trost, B., Unold, W., and Platt, U.: DOAS-observation of halogen radical-catalysed arctic boundary layer ozone destruction during the ARCTOC-campaigns 1995 and 1996 in Ny-Ålesund, Spitsbergen, Tellus, 49B, 5, 533-555, doi:10.1034/j.1600-0889.49, 1997. 7393, 7413, 7414

Vogt, R., Crutzen, P. J., and Sander, R.: A mechanism for halogen release from sea-salt aerosol in the remote marine boundary layer, Nature, 383, 327-330, doi:10.1038/383327a0, 1996. 7395

von Glasow, R. and Crutzen, P. J.: Model study of multiphase DMS oxidation with a focus on

15 halogens, Atmos. Chem. Phys., 4, 589-608, 2004,

http://www.atmos-chem-phys.net/4/589/2004/. 7396, 7400

von Glasow, R. and Crutzen, P. J.: Tropospheric Halogen Chemistry, in: Treatise on Geochemistry Update1, Vol. 4.02, edited by: Holland, H. D. and Turekian, K. K., 1-67, 2007. 7394

von Glasow, R., Sander, R., Bott, A., and Crutzen, P. J.: Modeling halogen chemistry in the marine boundary layer. 2 . Interactions with sulfur and cloud-covered MBL, J. Geophys. Res., 107, D17, 4323, doi:10.1029/2001JD000943, 2002a. 7396

von Glasow, R., Sander, R., Bott, A., and Crutzen, P. J.: Modeling halogen chemistry in the marine boundary layer 1. Cloud-free MBL, J. Geophys. Res., 107, D17, 4341, doi:10.1029/2001JD000942, 2002b. 7396, 7398, 7399

Wagner, T. and Platt, U.: Observation of Tropospheric BrO from the GOME satellite, Nature, 395, 486-490, 1998. 7393

Woodcock, A. H.: Salt nuclei in marine air as a function of altitude and wind force, J. Meteor., 10, 362-371, 1953. 7397

Worthy, D. E. J., Trivett, N. B. A., Hopper, J. F., and Bottenheim, J.: Analysis of long-range trans30 port events at Alert, Northwest Territories, during the Polar Sunrise Experiment, J. Geophys. Res., 99, D12, 25 329-25344, doi:10.1029/94JD01209, 1994. 7438

Zeng, T., Wang, Y., Chance, K., Browell, E. V., Ridley, B. A., and Atlas, E. L.: Widespread persistent near-surface ozone depletion at northern high latitudes in spring, Geophys. Res.

\section{The chemistry influencing ODEs}

M. Piot and R. von

Glasow

Title Page

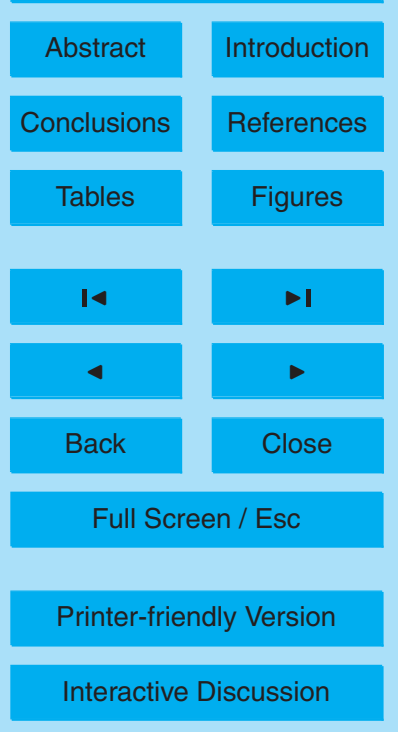


Lett., 30, 24, 2298, doi:10.1029/2003GL018587, 2003. 7393

Zhou, X., Beine, H. J., Honrath, R. E., Fuentes, J. D., Simpson, W., Shepson, P. B., and Bottenheim, J. W.: Snowpack Photochemical production of HONO: A Major Source of $\mathrm{OH}$ in the Arctic Boundary Layer in Springtime, Geophys. Res. Lett., 28, 21, 4087-4090,

\section{ACPD}

$8,7391-7453,2008$

The chemistry influencing ODEs

M. Piot and R. von

Glasow

\section{Title Page}

Abstract

Introduction

Conclusions

References

Tables

Figures

14

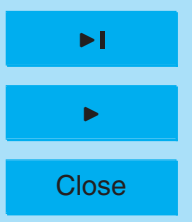

Back

Full Screen / Esc

Printer-friendly Version

Interactive Discussion 


\section{ACPD}

$8,7391-7453,2008$

Table 1. Differences in air composition between background and coastal air conditions.

\begin{tabular}{|c|c|c|}
\hline Species & $\begin{array}{c}\xi_{\text {background }} \\
(\mathrm{nmol} \mathrm{mol}\end{array}$ & $\left.\begin{array}{c}\xi_{\text {coastal }} \\
(\mathrm{nmol} \mathrm{mol} \\
-1\end{array}\right)$ \\
\hline $\mathrm{CH}_{3} \mathrm{Br}$ & 0.0 & 0.012 \\
\hline $\mathrm{CHBr}_{3}$ & 0.0 & 0.006 \\
\hline DMS & 0.0 & $0.01^{(\mathrm{a})}$ \\
\hline Fluxes & molec $\mathrm{cm}^{-2} \mathrm{~s}^{-1}$ & molec $\mathrm{cm}^{-2} \mathrm{~s}^{-1}$ \\
\hline DMS & 0.0 & $2.0 \times 10^{9(b)}$ \\
\hline $\mathrm{NH}_{3}$ & 0.0 & $4.0 \times 10^{8}$ \\
\hline Sea salt prod. & No & Yes \\
\hline
\end{tabular}

\section{The chemistry influencing ODEs}

M. Piot and R. von

Glasow

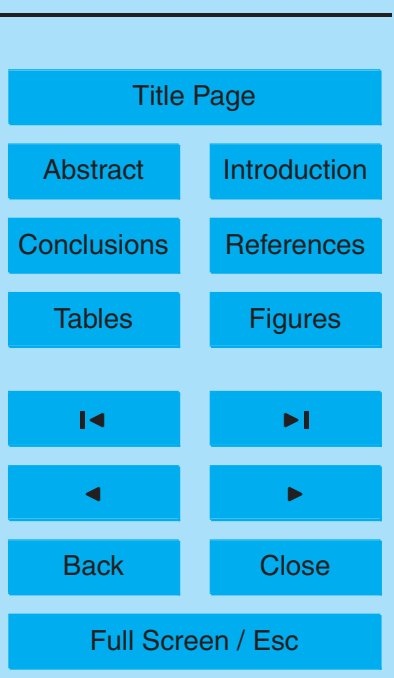

Printer-friendly Version

(a): Ferek et al. (1995)

(b): estimated from Quinn et al. (1990)

Interactive Discussion 


\section{ACPD}

$8,7391-7453,2008$

\section{The chemistry influencing ODEs}

M. Piot and R. von

Glasow

Table 2. Initial composition of sea salt aerosols (Jaenicke, 1988; Andrews et al., 2004).

\begin{tabular}{lccccccccc}
\hline Species & $\mathrm{Cl}^{-}$ & $\mathrm{Na}^{+}$ & $\mathrm{Mg}^{2+}$ & $\mathrm{SO}_{4}^{2-}$ & $\mathrm{K}^{+}$ & $\mathrm{Ca}^{2+}$ & $\mathrm{HCO}_{3}^{-}$ & $\mathrm{Br}^{-}$ & $\mathrm{I}^{-}$ \\
\hline Concentration $\left(\mathrm{mmol} \mathrm{I}^{-1}\right)$ & 550 & 470 & 53 & 28 & 10 & 10 & 2 & 0.85 & 0.001 \\
\hline
\end{tabular}

Interactive Discussion 


\section{ACPD}

$8,7391-7453,2008$

Table 3. Initial mixing ratios $(\xi)$ for gas phase species under background conditions.

\begin{tabular}{|c|c|c|}
\hline Species & $\xi\left(\mathrm{nmol} \mathrm{mol}{ }^{-1}\right)$ & Reference \\
\hline $\mathrm{SO}_{2}$ & 0.01 & Barrie and Hoff (1984), Bottenheim et al. (1990) \\
\hline $\mathrm{O}_{3}$ & 40.0 & Bottenheim et al. (1986), Anlauf et al. (1994) \\
\hline $\mathrm{NO}_{2}$ & 0.02 & Beine et al. (1997) \\
\hline $\mathrm{HNO}_{3}$ & 0.05 & Leaitch et al. (1994), Ridley et al. (2003) \\
\hline HONO & 0.01 & Li (1994), Zhou et al. (2001) \\
\hline $\mathrm{RONO}_{2}$ & 0.14 & Sander et al. (1997) \\
\hline PAN & 0.3 & Ridley et al. (2003), Stroud et al. (2003) \\
\hline $\mathrm{CO}$ & 150.0 & Ramacher et al. (1999) \\
\hline Methane & 1800.0 & Worthy et al. (1994) \\
\hline Ethane & 1.5 & Jobson et al. (1994), Hopper et al. (1994) \\
\hline Ethene & 0.08 & Bottenheim et al. (2002b) \\
\hline $\mathrm{HCHO}$ & 0.1 & Barrie et al. (1994), Sumner and Shepson (1999) \\
\hline $\mathrm{H}_{2} \mathrm{O}_{2}$ & 0.3 & de Serves (1994), Snow et al. (2002) \\
\hline
\end{tabular}

The chemistry influencing ODEs

M. Piot and R. von

Glasow

Title Page

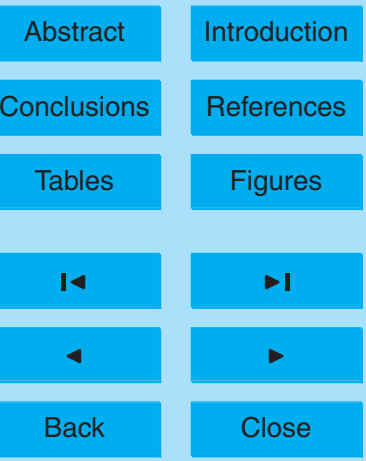

Full Screen / Esc

Printer-friendly Version

Interactive Discussion 


\section{ACPD}

8, 7391-7453, 2008

The chemistry influencing ODEs

M. Piot and R. von

Glasow

Table 4. Prescribed halogen fluxes in molec $\mathrm{cm}^{-2} \mathrm{~s}^{-1}$. High fluxes of chlorine are discussed in Sect. 4.6.

\begin{tabular}{cccc}
\hline & $\left.\begin{array}{c}\text { Partial ODE-P4 } \\
(\text { molec cm }\end{array} \mathrm{cs}^{-1}\right)$ & $\left.\begin{array}{c}\text { Major ODE-M4 } \\
(\text { molec cm }\end{array} \mathrm{s}^{-1}\right)$ & $\begin{array}{c}\text { Major ODE-M1 } \\
\left(\text { molec cm } \mathrm{cm}^{-2} \mathrm{~s}^{-1}\right)\end{array}$ \\
\hline $\mathrm{Br}_{2}$ & $5.0 \times 10^{7}$ & $9.0 \times 10^{7}$ & $1.5 \times 10^{9}$ \\
$\mathrm{BrCl}$ & $1.0 \times 10^{8}$ & $1.9 \times 10^{8}$ & $3.4 \times 10^{9}$ \\
$\mathrm{Cl}_{2}$ & $3.0 \times 10^{9}$ & $2.0 \times 10^{10}$ & $3.0 \times 10^{11}$ \\
\hline
\end{tabular}

Title Page

Abstract

Introduction

Conclusions

References

Tables

Figures

14

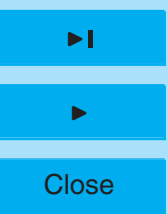

Back 


\section{ACPD}

8, 7391-7453, 2008

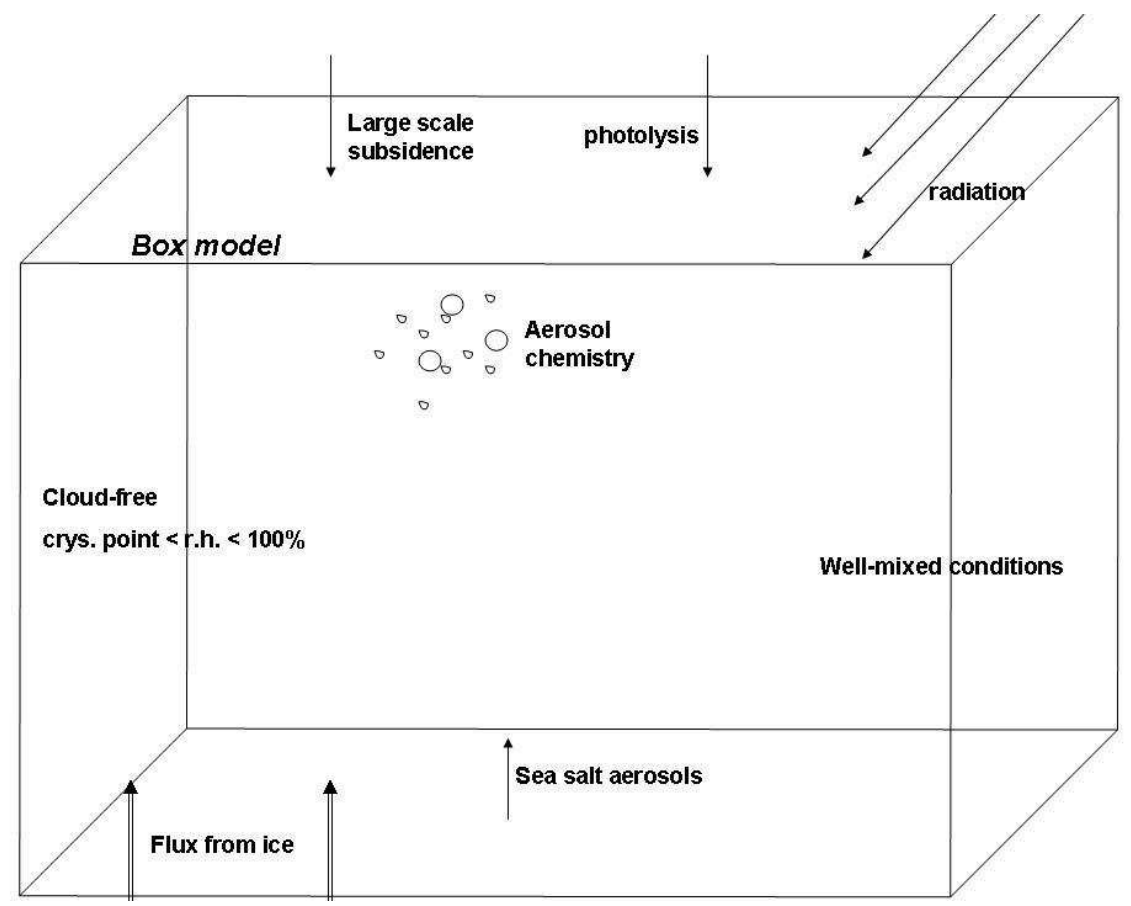

The chemistry influencing ODEs

M. Piot and R. von

Glasow

Title Page

Abstract

Introduction

Conclusions

References

Tables

Figures

14

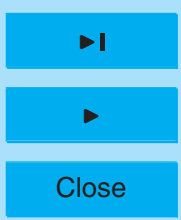

Back

Close

Full Screen / Esc

Fig. 1. Schematic depiction of the most important processes included in the box model version of MISTRA, applied for Arctic conditions. Fluxes from ice and sea salt production are switched ON/OFF, depending on the air mass type (see text and Table 1).

Printer-friendly Version

Interactive Discussion 


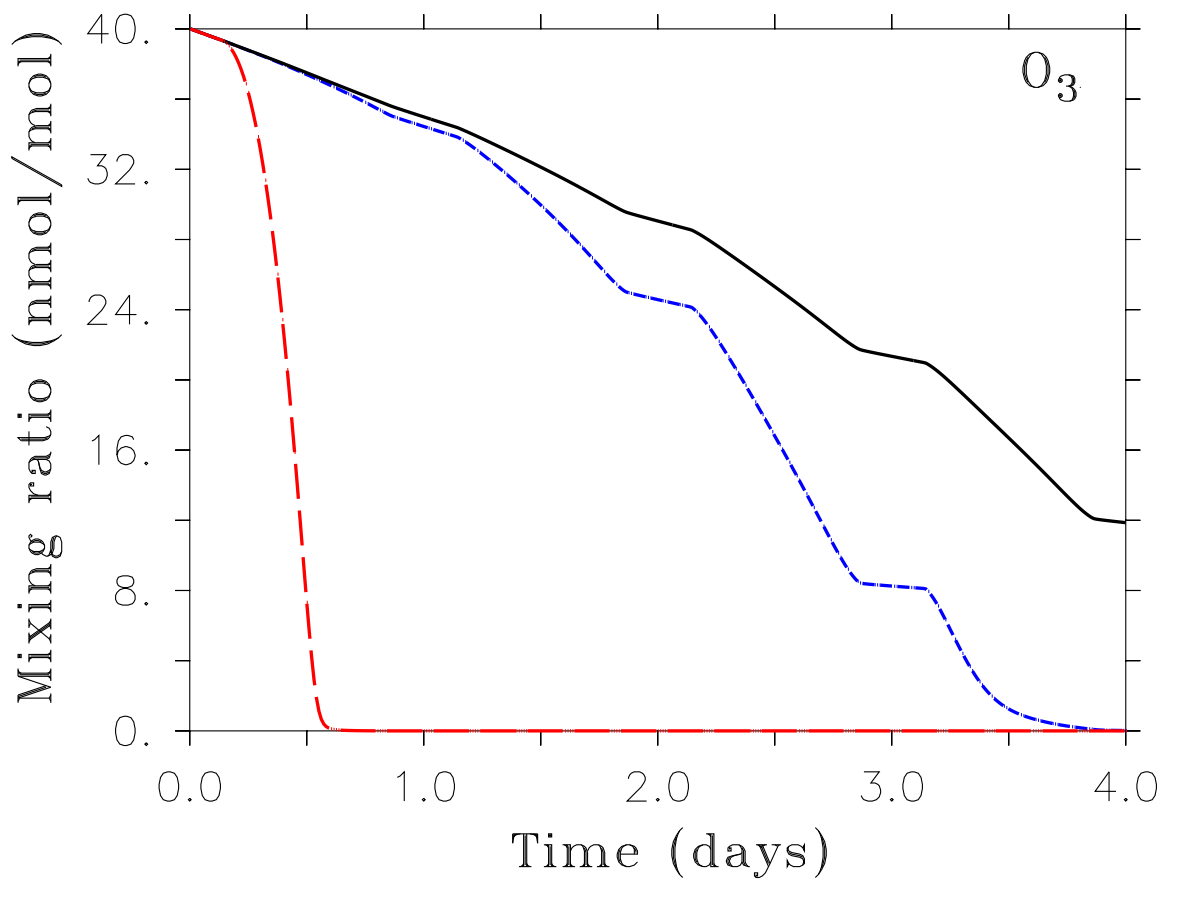

Fig. 2. $\mathrm{Br}_{2}$-induced ozone depletions ( $\mathrm{M} 1, \mathrm{M} 4$, and $\mathrm{P} 4$, see text). Solid black line: $F_{\mathrm{Br}_{2}}=5.0 \times 10^{7}$ molec cm $\mathrm{cm}^{-2} \mathrm{~s}^{-1}$; dashed blue line: $F_{\mathrm{Br}_{2}}=9.0 \times 10^{7}$ molec $\mathrm{cm}^{-2} \mathrm{~s}^{-1}$; dashed red line: $F_{\mathrm{Br}_{2}}=1.5 \times 10^{9}$ molec $\mathrm{cm}^{-2} \mathrm{~s}^{-1}$. Respective $\mathrm{Cl}_{2}$ - and $\mathrm{BrCl}$-induced ODEs are not shown.

\section{ACPD}

$8,7391-7453,2008$

\section{The chemistry influencing ODEs}

M. Piot and R. von

Glasow

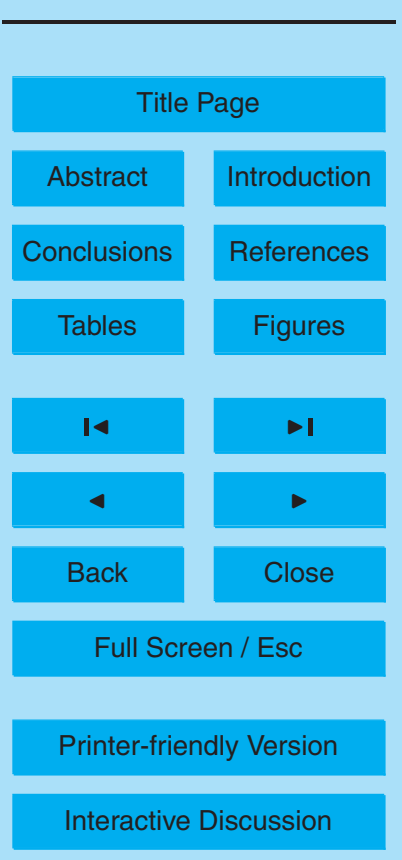

Interactive Discussion 


\section{ACPD}

\section{$8,7391-7453,2008$}
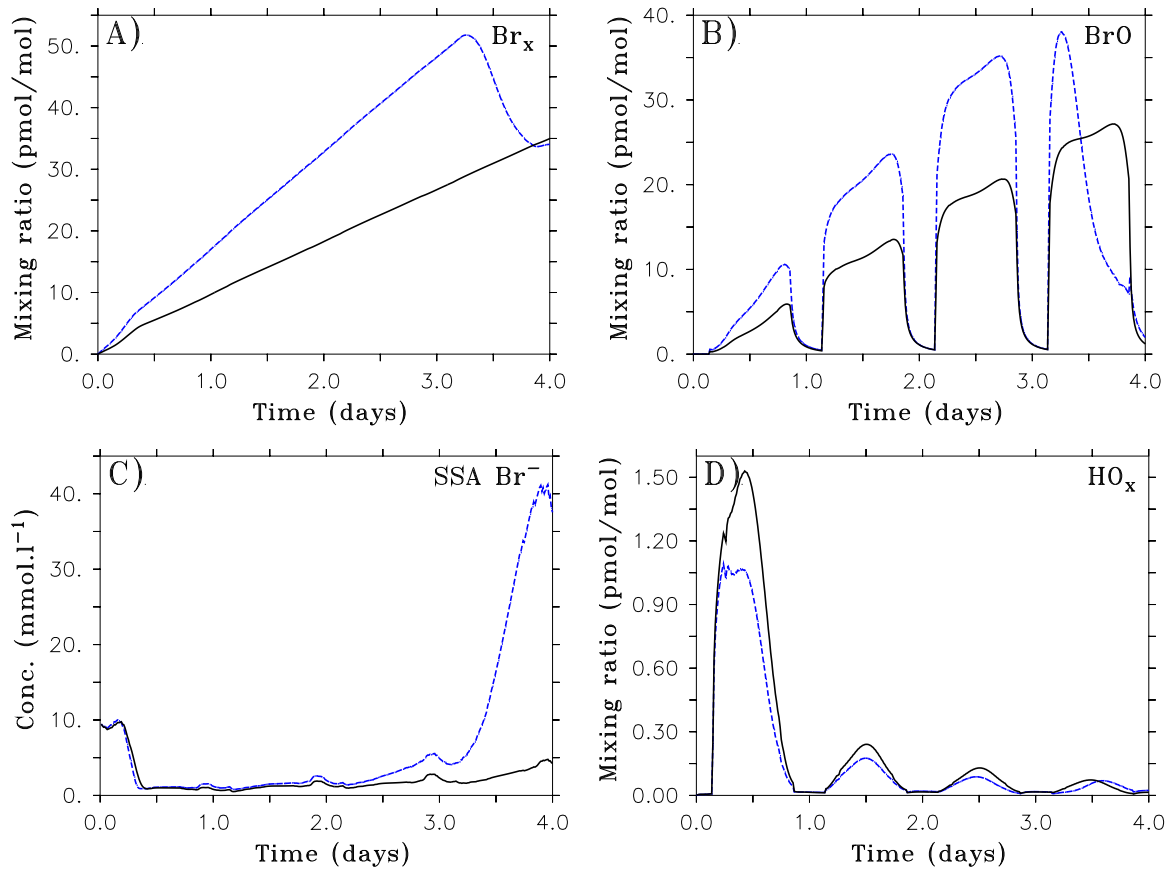

\section{The chemistry influencing ODEs}

M. Piot and R. von

Glasow

Title Page

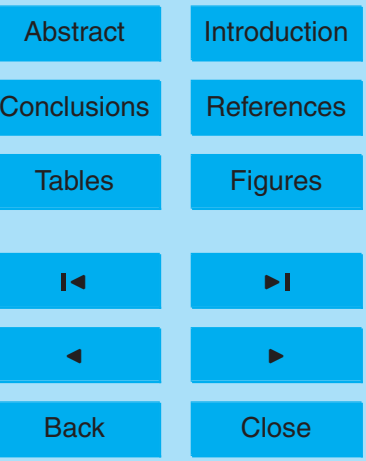

Full Screen / Esc

Fig. 3. Chemistry of $\mathrm{Br}_{2}$-induced $\mathrm{ODEs}$ for background air conditions. Solid black line: base run $\mathrm{Br}_{2}-\mathrm{P} 4$; dashed blue line: base run $\mathrm{Br}_{2}-\mathrm{M} 4$. (A) total gas phase bromine $\mathrm{Br}_{\mathrm{x}},(\mathrm{B}) \mathrm{BrO}$, (C) sea salt aerosol $\mathrm{Br}^{-}$, (D) $\mathrm{HO}_{x}\left(\mathrm{OH}+\mathrm{HO}_{2}\right)$. 


\section{ACPD}

\section{$8,7391-7453,2008$}
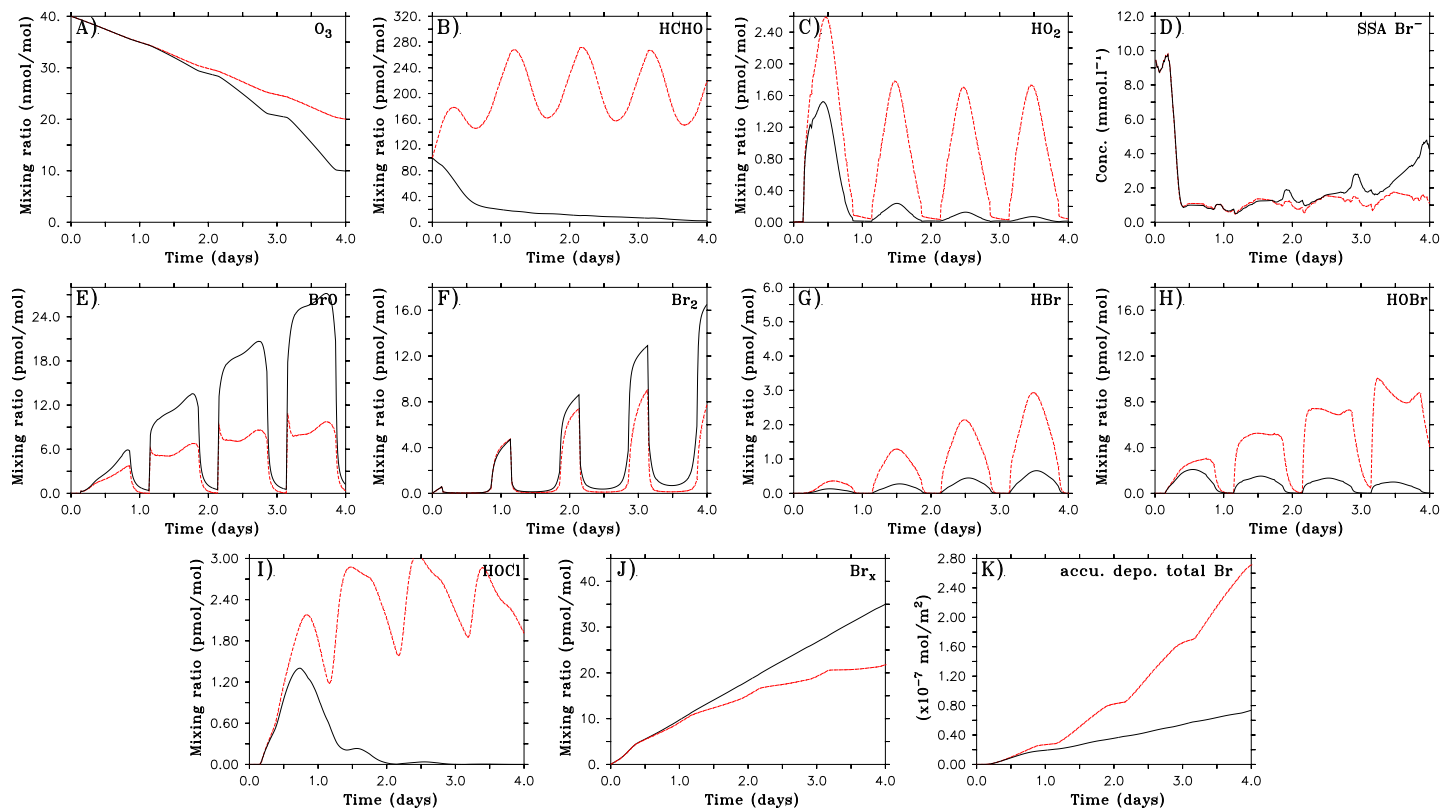

Fig. 4. Solid black line: base run $\mathrm{Br}_{2}-\mathrm{P} 4$; dashed red line: $\mathrm{Br}_{2}-\mathrm{P} 4-\mathrm{HCHO}=5.0 \times 10^{9}$ molec $\mathrm{cm}^{-2} \mathrm{~s}^{-1}$. Background air conditions. (A) $\mathrm{O}_{3}$, (B) $\mathrm{HCHO}$, (C) $\mathrm{HO}_{2}$, (D) sea salt aerosol $\mathrm{Br}^{-}$, (E) BrO, (F) $\mathrm{Br}_{2}$, (G) $\mathrm{HBr}$, (H) $\mathrm{HOBr}$, (I) $\mathrm{HOCl}$, (J) total bromine $\mathrm{Br}_{\mathrm{x}}$, (K) accumulated deposition of total gas phase bromine on snow.

The chemistry influencing ODEs

M. Piot and R. von

Glasow

Title Page

Abstract

Introduction

Conclusions

References

Tables

Figures

14

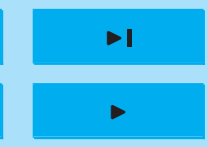

Back

Close

\section{Full Screen / Esc}

Printer-friendly Version

Interactive Discussion 

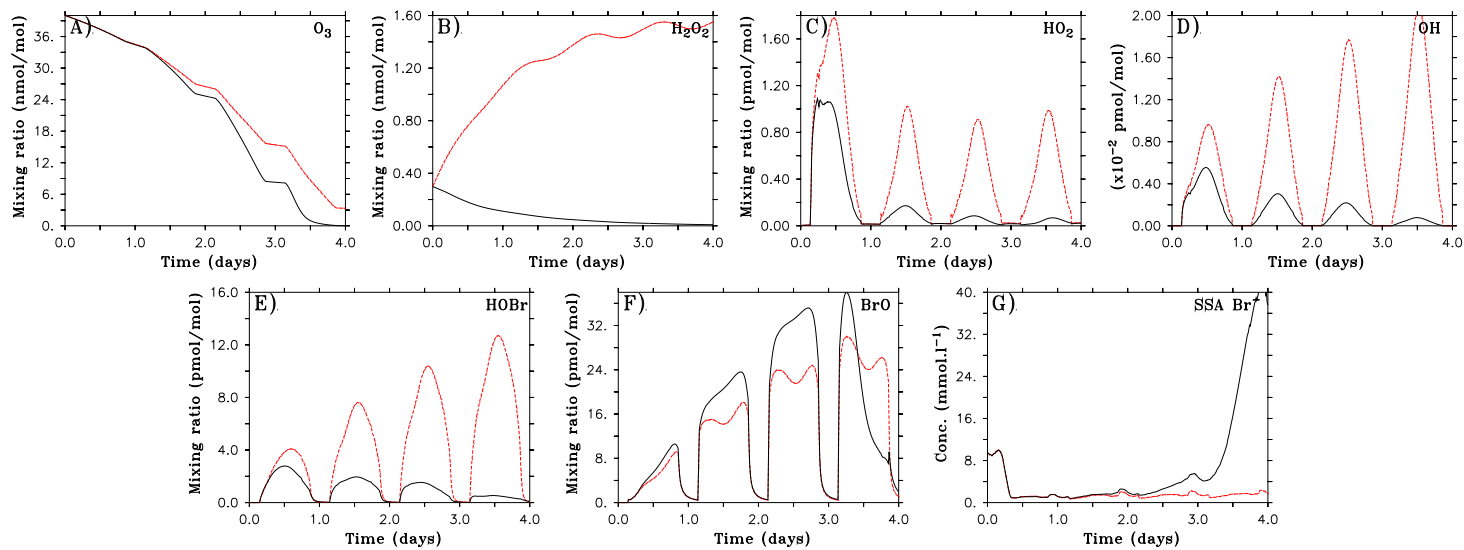

Fig. 5

Solid black line:

base run $\mathrm{Br}_{2}-\mathrm{M} 4$

dashed $\mathrm{H}_{2} \mathrm{O}_{2}=1.5 \times 10^{10}$ molec cm $\mathrm{cs}^{-1}$. Background air conditions. (A) $\mathrm{O}_{3}$, (B) $\mathrm{H}_{2} \mathrm{O}_{2}$, (C) $\mathrm{HO}_{2}$, (D)

red line: $\mathrm{H}_{2} \mathrm{O}_{2}=1.5 \times 10^{10}$ molec cm $\mathrm{cs}^{-2}$. Background air conditions. (A) $\mathrm{O}_{3}$, (B) $\mathrm{H}_{2} \mathrm{O}_{2}$, (C) $\mathrm{HO}_{2}$, (D) $\mathrm{OH},(\mathrm{E}) \mathrm{HOBr}$, (F) BrO, (G) sea salt aerosol $\mathrm{Br}^{-}$.
The chemistry influencing ODEs

M. Piot and R. von

Glasow

\section{Title Page}

4

Full Screen / Esc

Printer-friendly Version

Interactive Discussion 


\section{ACPD}

\section{$8,7391-7453,2008$}
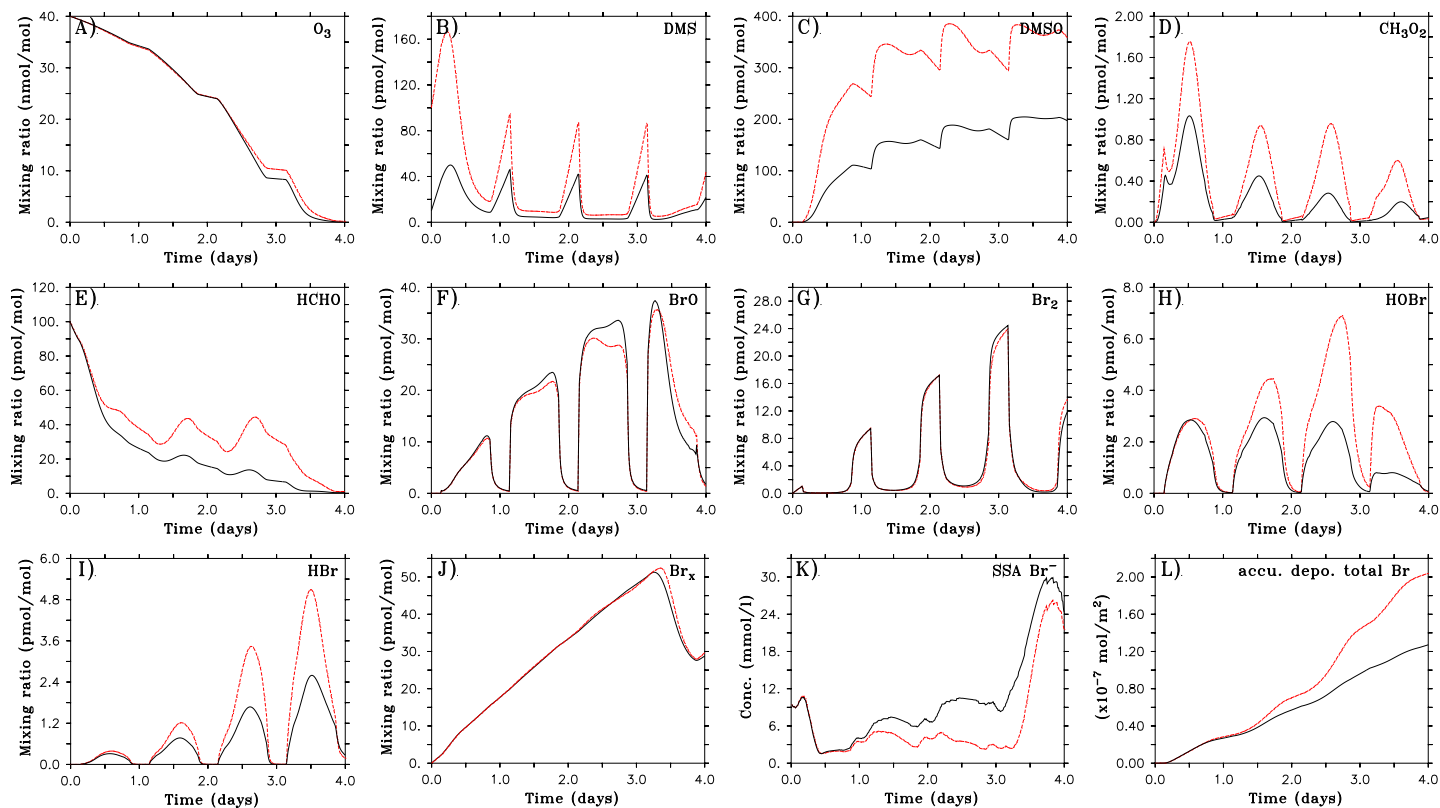

Fig. 6. Solid black line: $\mathrm{Br}_{2}-\mathrm{M} 4$; dashed red line: $\mathrm{Br}_{2}-\mathrm{M} 4-\mathrm{DMS}=0.1 \mathrm{nmol} \mathrm{mol}{ }^{-1}$ with a flux of $4.0 \times 10^{9}$ molec cm $\mathrm{cm}^{-1}$. Coastal air conditions. (A) $\mathrm{O}_{3}$, (B) DMS, (C) DMSO, (D) $\mathrm{CH}_{3} \mathrm{O}_{2}$, (E) $\mathrm{HCHO}$, (F) BrO, (G) $\mathrm{Br}_{2}$, (H) $\mathrm{HOBr}$, (I) $\mathrm{HBr}$, (J) total bromine $\mathrm{Br}_{\mathrm{x}}$, (K) sea salt aerosol $\mathrm{Br}^{-}$, (L) accumulated deposition of total gas phase bromine.

The chemistry influencing ODEs

M. Piot and R. von

Glasow

Title Page

Abstract

Introduction

Conclusions

References

Tables

Figures

14

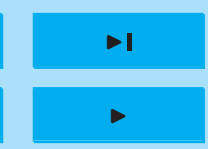

Back

Close

\section{Full Screen / Esc}

Printer-friendly Version

Interactive Discussion 


\section{ACPD}

$8,7391-7453,2008$

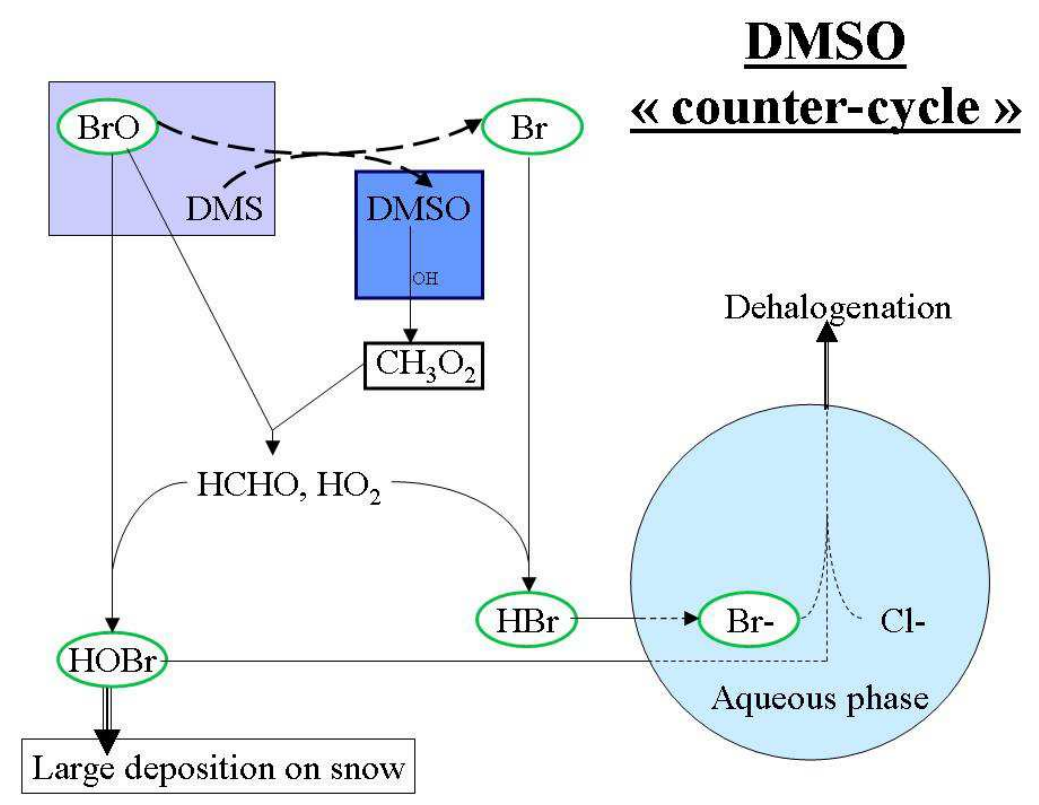

The chemistry influencing ODEs

M. Piot and R. von

Glasow

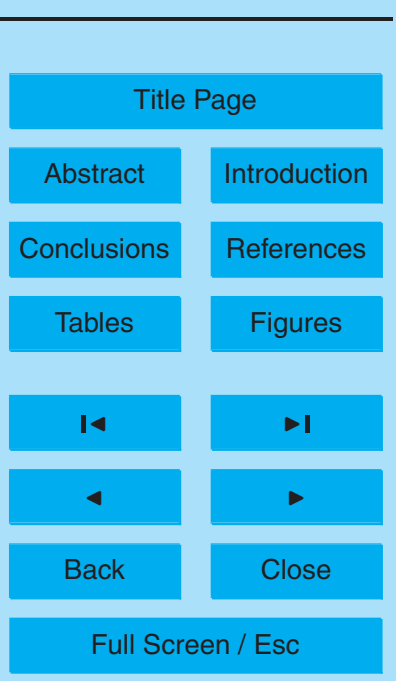

Fig. 7. Schematic description of the DMS chemistry and the DMSO "counter-cycle". The initiating reaction is depicted as bold dashed line. The reaction highlighted in the blue square is the key reaction producing $\mathrm{CH}_{3} \mathrm{O}_{2}$. 


\section{ACPD}

8, 7391-7453, 2008

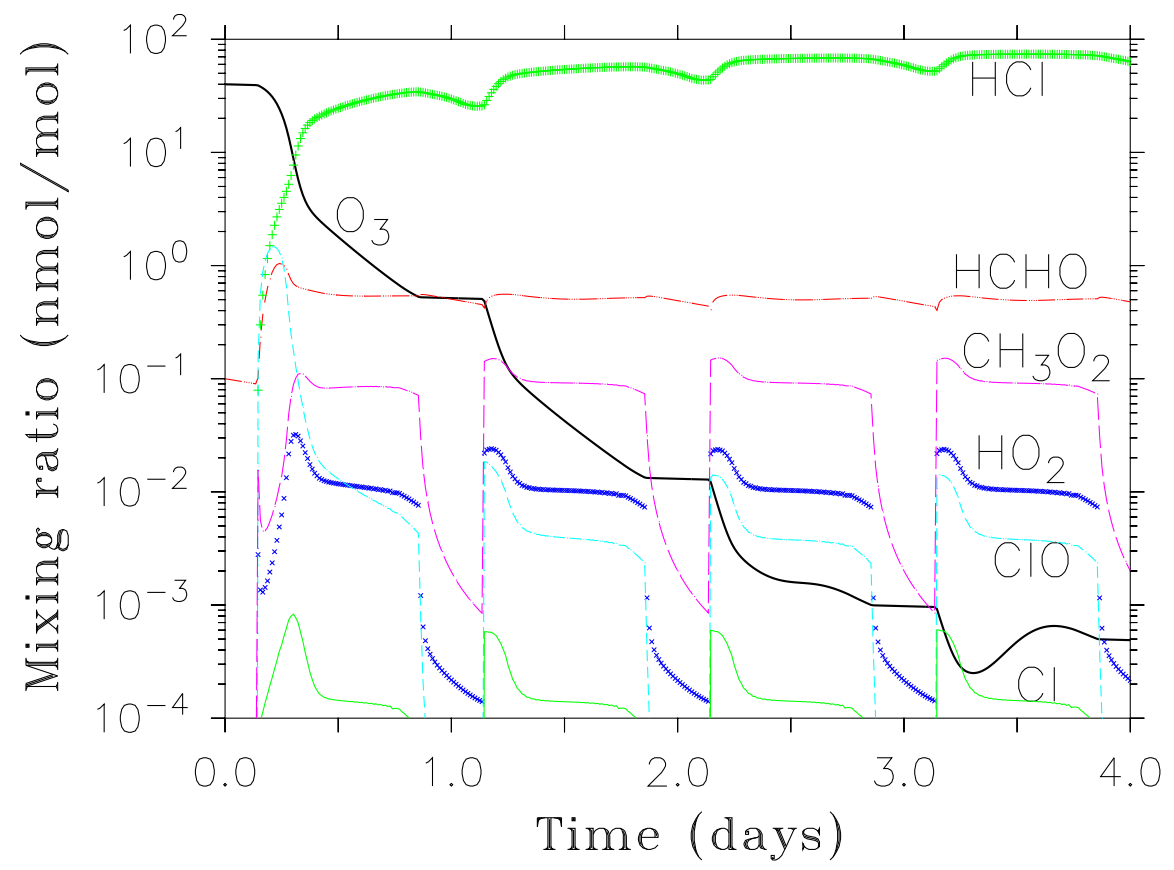

Fig. 8. Simulated evolution of gas phase $\mathrm{O}_{3}, \mathrm{HCHO}, \mathrm{HO}_{2}, \mathrm{HCl}, \mathrm{ClO}, \mathrm{Cl}$, and $\mathrm{CH}_{3} \mathrm{O}_{2}$ using the $\mathrm{Cl}_{2}-\mathrm{M} 1$ base run.

\section{The chemistry influencing ODEs}

M. Piot and R. von

Glasow

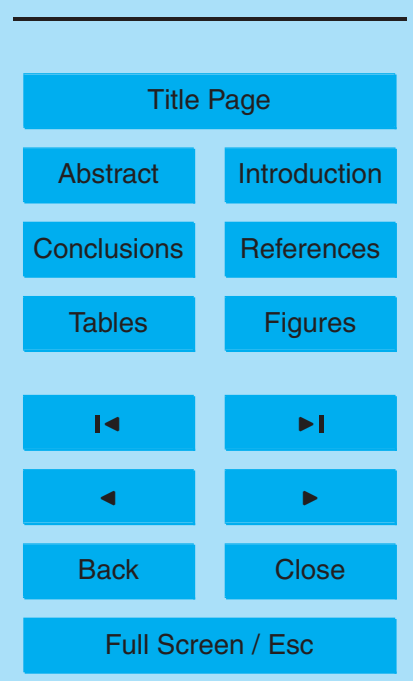

Printer-friendly Version

Interactive Discussion 


\section{ClO "Counter-cycle"}

\section{ACPD}

8, 7391-7453, 2008

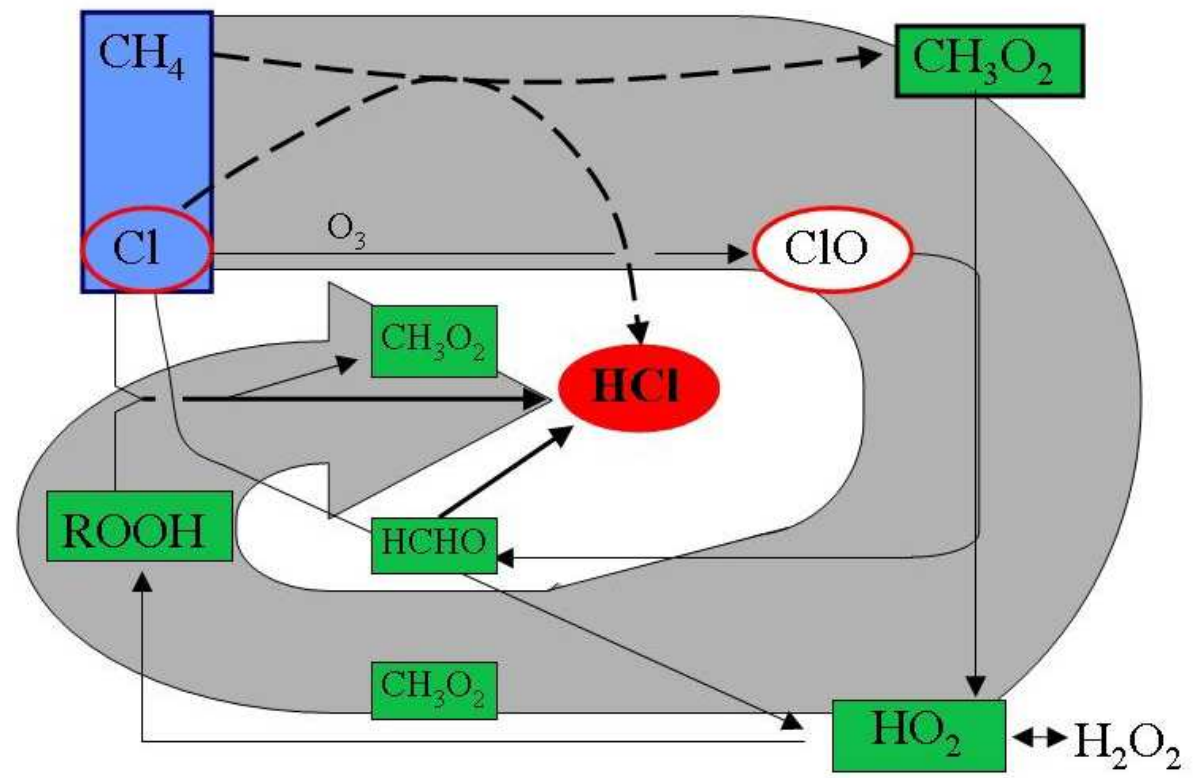

The chemistry influencing ODEs

M. Piot and R. von

Glasow

Title Page

Abstract

Introduction

Conclusions

References

Tables

Figures

14

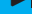

4

\section{Full Screen / Esc}

Fig. 9. Most important reactions caused by high mixing ratios of gaseous $\mathrm{Cl}_{2}$. The initiating reaction is highlighted by a blue square. Red circles: chlorine species. Green squares: key species for the $\mathrm{HCl}$ production. The grey arrow in background is to show the overall direction taken by the "chlorine counter-cycle".

Printer-friendly Version

Interactive Discussion 

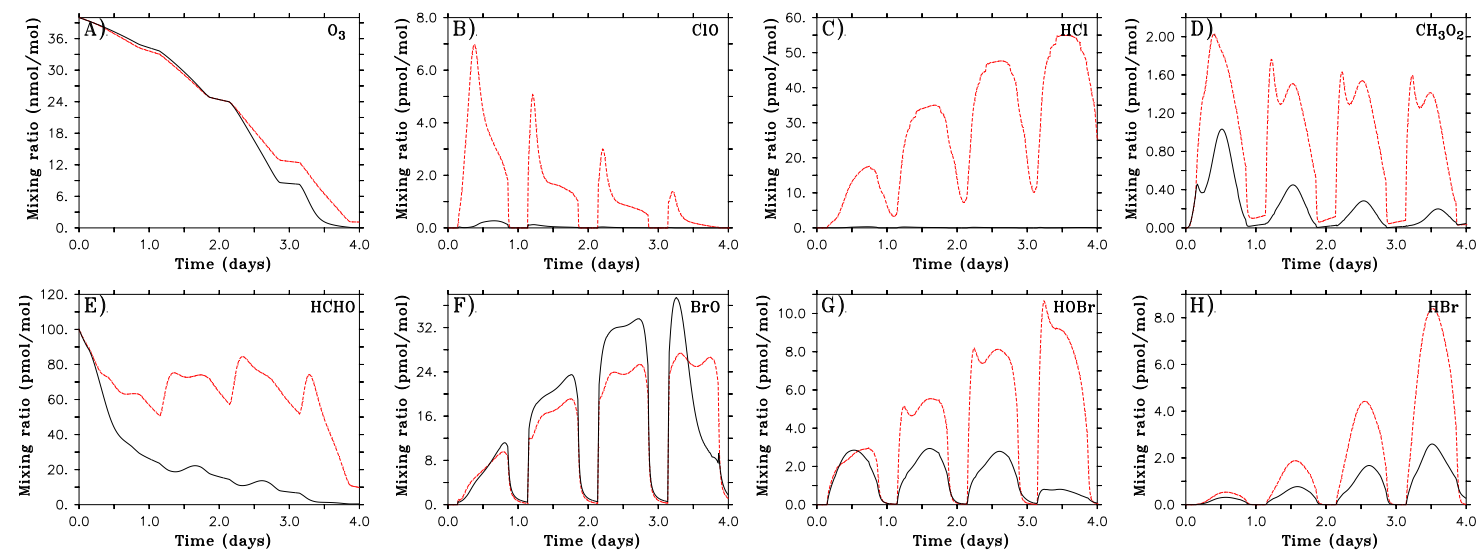

Fig. 10. Solid black line: $\mathrm{Br}_{2}-\mathrm{M} 4$; Dashed red line: $\mathrm{Br}_{2}-\mathrm{M} 4-\mathrm{Cl}_{2}=5.0 \times 10^{8} \mathrm{molec} \mathrm{cm}^{-2} \mathrm{~s}^{-1}$. Coastal air conditions. (A) $\mathrm{O}_{3}$, (B) $\mathrm{ClO}$, (C) $\mathrm{HCl}$, (D) $\mathrm{CH}_{3} \mathrm{O}_{2}$, (E) $\mathrm{HCHO}$, (F) $\mathrm{BrO}$, (G) $\mathrm{HOBr},(\mathrm{H}$ ) $\mathrm{HBr}$.

The chemistry influencing ODEs

M. Piot and R. von

Glasow

Title Page

Abstract

Introduction

Conclusions

References

Tables

Figures

14

Full Screen / Esc

Printer-friendly Version

Interactive Discussion 


\section{ACPD}

$8,7391-7453,2008$
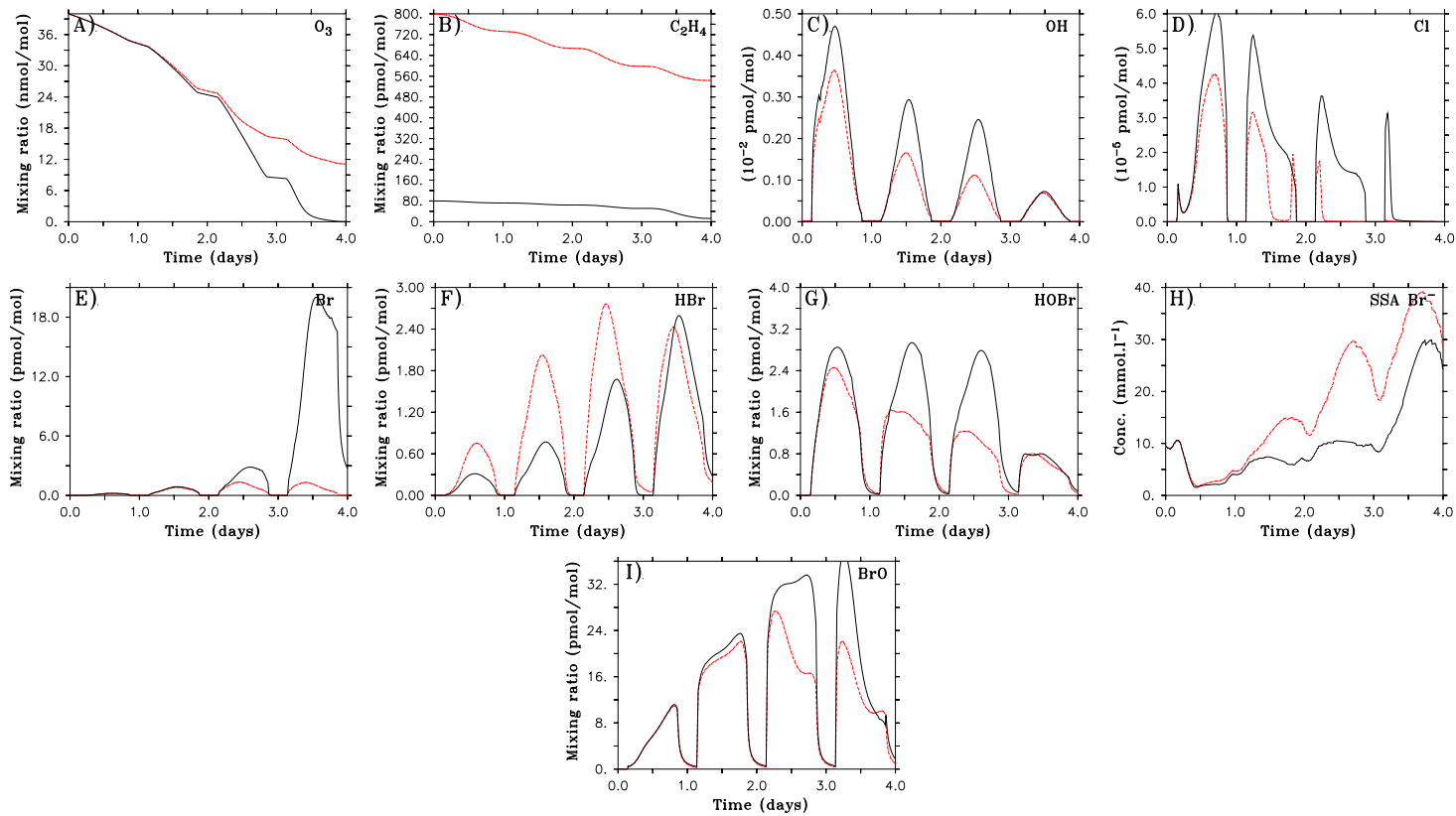

Fig. 11. Solid black line: $\mathrm{Br}_{2}-\mathrm{M} 4$; dashed red line: $\mathrm{Br}_{2}-\mathrm{M} 4-\mathrm{C}_{2} \mathrm{H}_{4}=0.8 \mathrm{nmol} \mathrm{mol}{ }^{-1}$. Coastal air conditions. (A) $\mathrm{O}_{3}$, (B) $\mathrm{C}_{2} \mathrm{H}_{4}$, (C) $\mathrm{OH}$, (D) $\mathrm{Cl}$, (E) $\mathrm{Br}$, (F) $\mathrm{HBr}$, (G) $\mathrm{HOBr}$, (H) sea salt aerosol $\mathrm{Br}^{-}$, (I) BrO.
The chemistry influencing ODEs

M. Piot and R. von

Glasow

Title Page

Abstract

Introduction

Conclusions

References

Tables

Figures

14

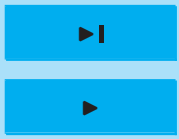

Back

Close

Full Screen / Esc

Printer-friendly Version

Interactive Discussion 


\section{ACPD}

8, 7391-7453, 2008
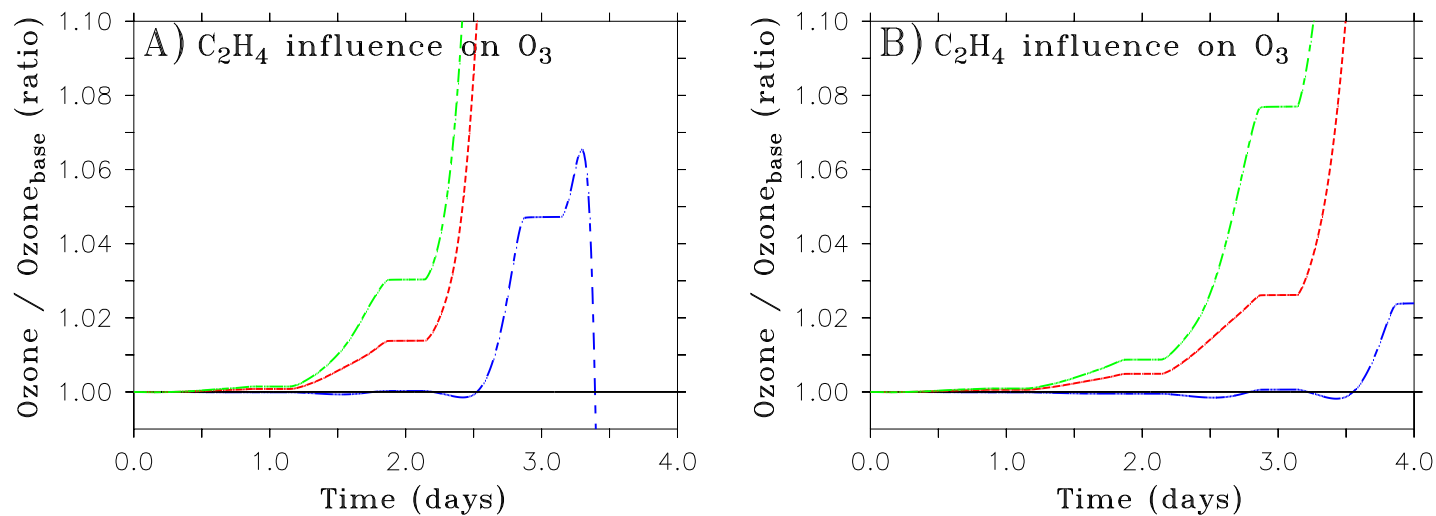

The chemistry influencing ODEs

M. Piot and R. von

Glasow

Title Page

Abstract

Introduction

Conclusions

References

Tables

Figures

14

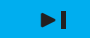

Fig. 12. Ratio of $\mathrm{O}_{3}$ in sensitivity runs to the base run for (A) M4 and (B) P4 ODEs, respectively. Dash-dotted blue line: $\xi_{\mathrm{C}_{2} \mathrm{H}_{4}}=0.01 \mathrm{nmol} \mathrm{mol}^{-1}$; dashed red line: $\xi_{\mathrm{C}_{2} \mathrm{H}_{4}}=0.5 \mathrm{nmol} \mathrm{mol}^{-1}$; dashdotted green line: $\xi_{\mathrm{C}_{2} \mathrm{H}_{4}}=0.8 \mathrm{nmol} \mathrm{mol}{ }^{-1}$. Coastal air conditions.

4

\section{Back}

\section{Full Screen / Esc}

Printer-friendly Version

Interactive Discussion 

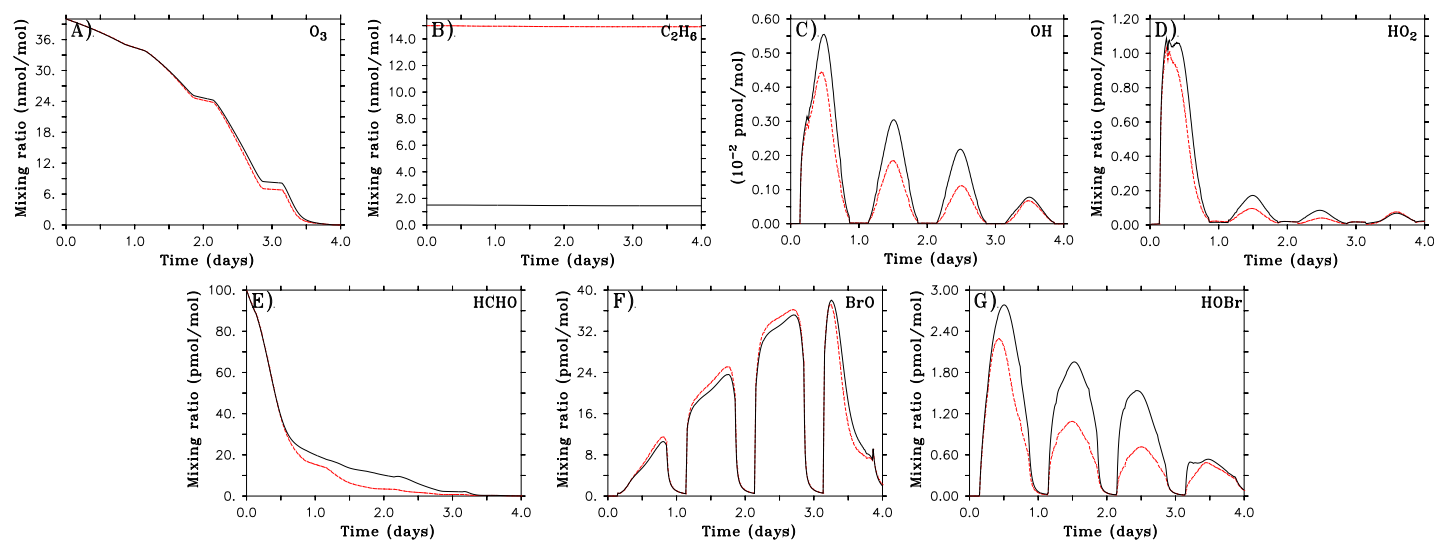

Fig. 13. Solid black line: $\mathrm{Br}_{2}-\mathrm{M} 4$; dashed red line: $\mathrm{Br}_{2}-\mathrm{M} 4-\mathrm{C}_{2} \mathrm{H}_{6}=15 \mathrm{nmol} \mathrm{mol}{ }^{-1}$. Background air conditions. (A) $\mathrm{O}_{3}$, (B) $\mathrm{C}_{2} \mathrm{H}_{6}$, (C) $\mathrm{OH}$, (D) $\mathrm{HO}_{2}$, (E) $\mathrm{HCHO}$, (F) $\mathrm{BrO}$, (G) $\mathrm{HOBr}$.
The chemistry influencing ODEs

M. Piot and R. von

Glasow

Title Page

Abstract

Introduction

Conclusions

References

Tables

Figures

14

4

Full Screen / Esc

Printer-friendly Version

Interactive Discussion 

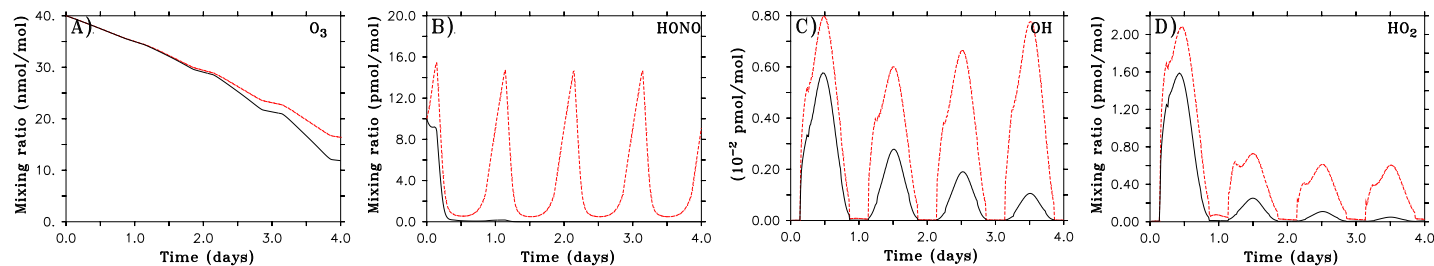

The chemistry influencing ODEs

\section{Piot and R. von}

Glasow
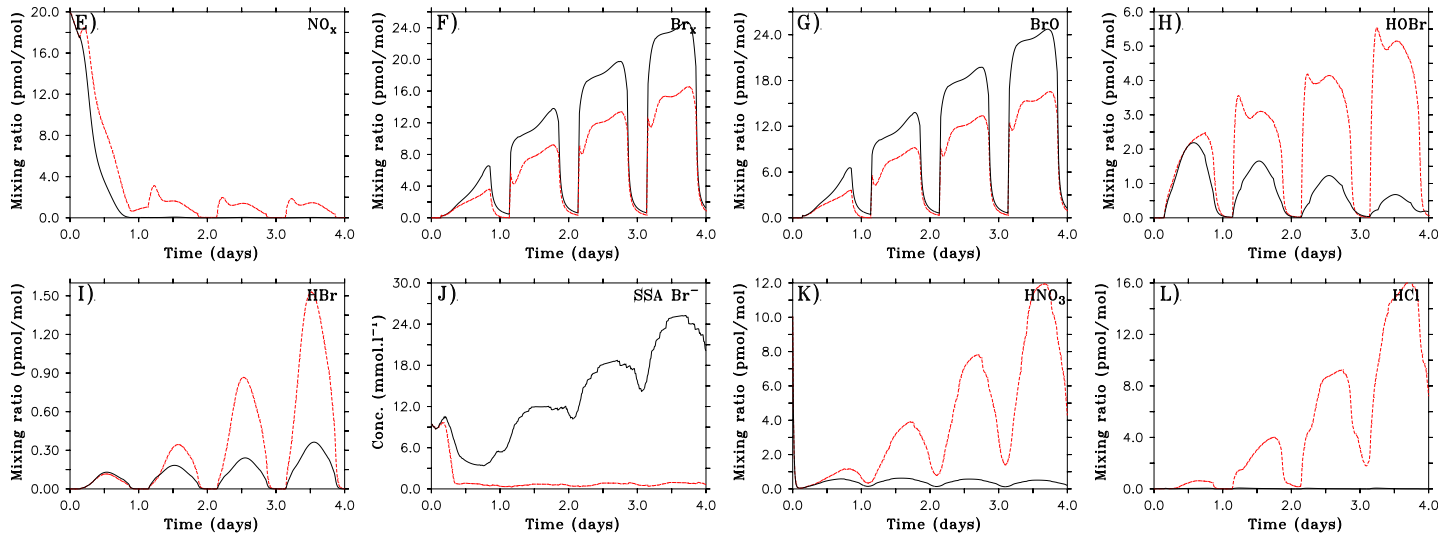

Fig. 14. Solid black line: $\mathrm{Br}_{2}-\mathrm{P} 4$; dashed red line: $\mathrm{Br}_{2}-\mathrm{P} 4-\mathrm{HONO}=5.0 \times 10^{8} \mathrm{molec} \mathrm{cm}^{-2} \mathrm{~s}^{-1}$. Background air conditions. (A) $\mathrm{O}_{3}$, (B) $\mathrm{HONO}$, (C) $\mathrm{OH}$, (D) $\mathrm{HO}_{2}$, (E) $\mathrm{NO}_{\mathrm{x}}$, (F) total bromine $\mathrm{Br}_{\mathrm{x}}$, (G) $\mathrm{BrO}$, (H) $\mathrm{HOBr}$, (I) $\mathrm{HBr}$, (J) sea salt aerosol $\mathrm{Br}^{-}$, (K) $\mathrm{HNO}_{3}$, (L) $\mathrm{HCl}$.

Title Page

Abstract Introduction

Conclusions

References

Tables

Figures

14

4

Back

Full Screen / Esc

Printer-friendly Version

Interactive Discussion 